\title{
An Assessment of the Available Windy Land Area and Wind Energy Potential in the Contiguous United States
}

D. L. Elliott

L. L. Wendell

G. L. Gower

August 1991

Prepared for the U.S. Department of Energy under Contract DE-AC06-76RLO 1830

Pacific Northwest Laboratory

Operated for the U.S. Department of Energy

by Battelle Memorial Institute 


\title{
DISCLAIMER
}

This report was prepared as an account of work sponsored by an agency of the United Stakes Government. Neither the United States Government nor any agency thereof, nor Battelle Memorial Institute, nor any of their employees, makes any warranty, expressed or implied, or assumes any legal liability or responsibility for the accuracy, completeness, or usefulness of any information, apparatus, product, or process disclosed, or represents that its use would not infringe privately owned rights. Reference herein to any specific commercial product, process, or service by trade name, trademark, manufacturer, or otherwise does not necessarily constitute or imply its endorsement, recommendation, or favoring by the United States Government or any agency thereof, or Baltelle Memorial Institute. The views and opinions of authors expressed herein do not necessarily state or reflect those of the United States Government or any agency thereof.

\author{
PACIFIC NORTHWEST LABORATORY \\ operated by \\ BATTELLE MEMORIAL INSTITUTE \\ for the
}

UNITED STATES DEPARTMENT OF ENERGY

under Contract DE-ACO6-76RLO 1830

\author{
Printed in the United States of America
}

Available to DOE and DOE contractors from the

Office of Scientific and Technical Information, P.O. Box 62, Oak Ridge, TN 37831; prices available from (615) 576-6401. FTS 626-14401.

Available to the public from the National Technical Information 5ervice, U.S. Department of Commerce, 5245 Port Royal Rd., Springfield, VA 22161. 
PNL -7789

UC -261

AN ASSESSMENT OF THE AVAILABLE WINDY LAND AREA AND WIND ENERGY POTENTIAL.

IN THE CONTIGUOUS UNITED STATES
D. L. Elliott
L. L. Wende 11
G. L. Gower

August 1991

Prepared for the U.S. Department of Energy under Contract DE-ACO6-76RL0 1830

Pacific Northwest Laboratory Richland, Washington 99352 


\section{$\underline{\text { ABSTRACT }}$}

Estimates of 1 and areas with various levels of wind energy resource and resultant wind energy potential have been developed for each state in the contiguous United States. The estimates are based on published wind resource data and account for the exclusion of some windy lands as a result of environmental and land-use considerations. Despite these exclusions, the amount of wind resource estimated over the contiguous United States is surprisingly large and has the potential to supply a substantial fraction of the nation's energy needs, even with the use of today's wind turbine technology. Although this study shows that, after exclusions, only about $0.6 \%$ of the land area in the contiguous United States is characterized by high wind resource (comparable to that found in windy areas of California where wind energy is being costeffectively developed), the wind electric potential that could be extracted with today's technology from these areas across the United States is equivalent to about $20 \%$ of the current U.S. electric consumption.

Future advances in wind turbine technology will further enhance the potential of wind energy. As advances in turbine technology allow areas of moderate wind resource to be developed, more than a tenfold increase in the wind energy potential is possible. These areas, which cover large sections of the Great Plains and are widely distributed throughout many other sections of the country, have the potential of producing more than three times the nation's current electric consumption. Twelve states in the midsection of the country contribute over $90 \%$ of the wind electric potential in the contiguous United States and have the potential to produce several times their own electrical consumption, which puts them in a position to export electric power or use it for other applications. 


\section{SUMMARY}

In support of the U.S. Department of Energy's National Energy Strategy, estimates of land areas with various levels of wind energy resource and resultant wind electric potential have been developed for each state in the contiguous United States. The estimates are based on published wind resource data and account for the exclusion of some land as a result of environmental and land-use considerations. Windy lands excluded from wind energy development (under the scenario of moderate exclusion based on land use described here) include environmentally protected lands (such as parks and wi lderness areas), urban lands, wet]ands, and a substantial fraction of forest and agricultural lands. Only a small fraction of range and barren lands was excluded (to account for some land occupied by roads and structures), because wind plants have been successfully located in these types of land-use areas in California. Despite these exclusions, the amount of wind resource estimated over the contiguous United States is surprisingly large, and it is not limited by the availability of windy lands. That is, the wind resource has the potential of supplying a substantial fraction of the nation's energy needs, even with the use of today's technology.

Today's technology allows the exploitation of the wind resource mainly in specific areas where the annual average wind resource is class 5 or greater, that is, where the wind power density is $400 \mathrm{~W} / \mathrm{m}^{2}$ or greater at $30 \mathrm{~m}$ (100 ft) above the ground. Areas of class 5 and greater wind resource have annual average wind speeds of approximately $7 \mathrm{~m} / \mathrm{s}$ (16 mph) and higher at heights of $30 \mathrm{~m}(100 \mathrm{ft})$. To date, development of these areas has occurred primarily in California, where class 5 areas are being cost-effectively developed. Although this study shows that, after exclusions, only about $0.6 \%$ of the land area in the contiguous United States is characterized by class 5 or greater wind resource, the wind electric potential that could be extracted with today's technology from these areas across the United States is equivalent to about $20 \%$ of the current U.S. electric consumption. Three states--North Dakota, Wyoming, and Montana--could contribute about $80 \%$ of the U.S. wind electric potential from class 5 or greater wind resource areas. The wind electric potential in North Dakota, Wyoming, and Montana exceeds the electric 
consumption in these states by factors of 25.6, 14.8, and 7.4, respectively. Although California is the world leader in wind power generation (with over $80 \%$ of the world's capacity), the wind electric potential from class 51 ands in California contributes less than $3 \%$ of the wind potential possible from all class 5 lands in the contiguous United States. However, only about $20 \%$ of California's class 5 wind potential has been developed, according to our estimates of the land area potentially available after environmental and landuse exclusions.

Future advances in wind turbine technology will further enhance the potential of wind energy in the United States. These advances include improvements in airfoil designs and optimized controls that increase the energy-capture efficiency of wind turbines and improvements in structures and materials that allow taller and larger-diameter wind turbines to be developed, which in turn can reach more available wind energy more economically. As advances in turbine technology allow areas with lower wind resource to be developed, such as class 3 areas (where the annual average wind power density is 300 to $400 \mathrm{~W} / \mathrm{m}^{2}$ at $50-\mathrm{m}$ heights), more than a tenfold increase in the wind energy potential is possible. Areas with class 3 and greater wind resource, where annual average wind speeds at $50 \mathrm{~m}$ generally exceed $6.4 \mathrm{~m} / \mathrm{s}$ or about $14 \mathrm{mph}$, represent approximately 13\% of the contiguous U.S. Iand area. These areas, which cover large sections of the Great Plains stretching from Texas to the Dakotas, but which are also widely distributed throughout many other sections of the country, have the potential of displacing over 100 Quads (fossil-fuel equivalent) of electric energy annually. (A Quad is one quadrillion Btus.) Compare that with the total energy use of approximately 80 Quads in the contiguous United States in 1988, with $36 \%$ of that total having been devoted to the production of electricity. Twelve states in the midsection of the country contribute over $90 \%$ of the wind electric potential in the contiguous United States. They are, in order of greatest potential, North Dakota, Texas, Kansas, South Dakota, Montana, Nebraska, Wyoming, Oklahoma, Minnesota, Iowa, Colorado, and New Mexico. These states also have the potential to produce several times their own electrical consumption, which puts them in a position to export electric power or use it for other possible applications. Other states in the West, the Northeast, and in the vicinity 
of the Great Lakes have the potential to provide a substantial fraction of their own electrical consumption or, in some states with relatively iow consumption levels, even more than their own consumption.

Under the most severe land-use restriction, where essentially all lands except for range lands and barren lands in the west are excluded from wind energy development, the U.S. wind electric potential (with advanced technology) from 1 ands with class 3 or greater resource would be approximately 47 Quads (fossil-fuel equivalent) annually, which still exceeds the amount of energy currently consumed for electrical generation (about 30 Quads) in the United States. Although this scenario severely reduces the amount of windy iand area and wind electric potential in many of the midwestern and eastern states, wind electric potentials in many of the western states survive this scenario quite well, because large fractions of their windy lands are classified as range or barren lands. For example, Wyoming loses only 30\% of its wind electric potential under the most restrictive scenario.

Although this study provides quantitative estimates of the annual average wind electric potential, three qualifications must be emphasized. First, the results presented here must be regarded as estimates only because they would change with the use of different assumptions and specifications. Second, this study does not diminish the need for careful siting and array design before the actual installation of a wind plant. Third, wind is an intermittent resource, and wind technology must therefore be integrated with other baseload power sources to provide a stable utility system. Seasonal analyses of the wind electric potential, like those reported in this study for the annual average data, would be a refinement that would make the results more valuable to utilities and energy planners. Other important factors not addressed in this study that influence the area available and total wind electric potential include remoteness of the resource (transmission, access), match between production and demand (seasonal and daily, storage), utility and public acceptance, local ordinances, and other technological and institutional factors. (These factors and their implications on the development and deployment of wind-energy technologies are discussed in a DOE Interlaboratory White Paper, "The Potential of Renewable Energy".) 


\section{ACKNOWLEDGMENTS}

The authors would like to thank the following technical reviewers who took the time to read the draft report and provide comments useful to improving this document: Rich Barchet (Pacific Northwest Laboratory); Neil Kelley, Brian Parsons, and Jim Jones (Solar Energy Research Institute); Mary Ilyin and Steve Holets (Pacific Gas and Electric); Randy Johnson (Princeton Economic Research Institute); Al Germain (U.S. Windpower); and Bruce Bailey (AwS Scientific).

The authors would also like to acknowledge the following individuals at Pacific Northwest Laboratory for their valuable contributions: Rosemary 211 is for her assistance in typing and preparing this document; Laurel Grove, Regina Lundgren, and Betsy Owczarski for their assistance in editing the report; Kathy Kachele and others in the Graphics Department for their assistance in preparing many of the figures in the report. 


\section{CONTENTS}

ABSTRACT ...............................

SUMMARY ............................ . . . .

1.0 INTRODUCTION

2.0 WIND RESOURCE DATA ........................ 5

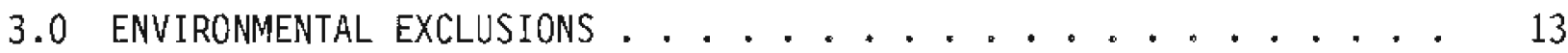

4.0 LAND-USE EXCLUSIONS . . . . . . . . . . . . . 17

5.0 ESTIMATES OF WINDY LANO AREA . . . .............. 27

5.1 SCENARIO 1 - NO EXCLUSIONS . . . . . . . . . . 34

5.2 SCENARIO 2 - ENVIRONMENTAL EXCLUSIONS . . . . . . . 36

5.3 SCENARIO 3 - ENVIRONMENTAL AND MODERATE LAND-USE EXCLUSIONS . 37

5.4 SCENARIO 4 - ENVIRONMENTAL AND SEVERE LAND-USE EXCLUSIONS * . 42

6.0 ESTIMATES OF WIND ENERGY POTENTIAL . . . . . . . . . . . . . 43

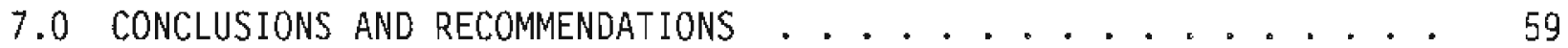

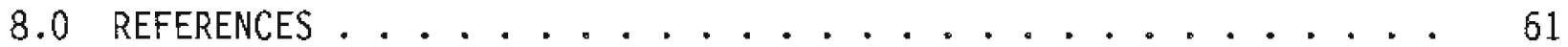

APPENDIX A - WIND TURBINE SPACINGS, ENERGY LOSSES, AND EFFICIENCY . . . A.1

APPENDIX B - ESTIMATES OF WINDY LAND AREA AND WIND ENERGY POTENTIAL, BY STATE ..................... B. 1 


\section{$\underline{\text { FIGURES }}$}

1 Gridded Map of Annual Average Wind Energy Resource Estimates in the Contiguous United States..................... . 6

2 Percentage of the Land Area Estimated to Have Class 3 or Higher Wind Power in the Contiguous United States .............. 10

3 Percentages of Land Area Excluded by Environmental Considerations for Each Class of Land-Surface Form . . . . . . . . . . . . . 14

4 Percentage of Each Grid Ce11 Excluded by Environmental

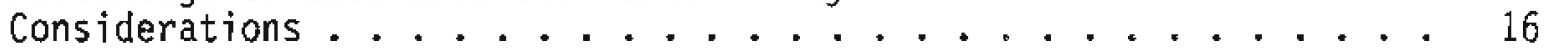

5 Maps of Land-Use Type from the Gridded Data Base . . . . . . . . . . 18

6 Windy Land Area in the Contiguous United States for Four Land

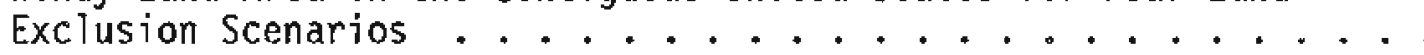

7 Available windy Land for Land Exclusion Scenario 3 and for a Wind Resource Specification of $\geq$ Class 5 and $\geq$ Class $3 \ldots . . . .$.

8 Available windy Land as a Percentage of Each State's Total Area for Land Exclusion Scenario 3 and for a Wind Resource Specification of $\geq$ class 5 and $\geq$ Class $3 . . . . . . . . . . . . .$.

9 Wind Energy Potential of the Contiguous United States for Four Land Exclusion Scenarios . . . . . . . . . . . . . . . .

10 Wind Electric Potential for 30-m Hub Height and Wind Resource $\geq$ Class 5 at $30 \mathrm{~m}$, and $50-\mathrm{m}$ Hub Height and Wind Resource $\geq$ Class 3 at 50

11 Wind Electric Potential as a Percentage of Contiguous U.S. 1990 Total Electric Consumption and 1988 Total Energy Consumption

12 Wind Electric Potential as a Percentage of Each State's 1990 Total Electric Consumption and 1988 Total Energy Consumption . 


\section{$\underline{\text { TABLES }}$}

1 Classes of Wind Power Density ............... 5

2 Comparison of Annual Average Wind Power at Three Sites with Identical Annual Average Wind Speeds at $10 \mathrm{~m} \ldots \ldots . . . .88$

3 Percentage of Land Area Excluded Under Moderate and Severe Land-Use Restrictions for Each Land-Use Type ........... 23

4 Windy Land Area in the Contiguous United States for Four Land Exclusion Scenarios in Units of Square Kilometers, Percentage of U.S. Land Area, and Ratio to the Base Case (Scenario 1) . . . . 29

5 State Land Area by Power Class for Land Exclusion Scenario 1 (No Exclusions) ...................... 30

6 State Land Area by Power Class for Land Exclusion Scenario 2 (Environmental Exclusions) ............. 31

7 State Land Area by Power Class for Land Exclusion Scenario 3 (Environmental and Moderate Land-Use Exclusions) . . . . . . . 32

8 State Land Area by Power Class for Land Exclusion Scenario 4 (Environmental and Severe Land-Use Exclusions) .......... 33

9 Average Power Intercepted, Average Power Output, and Annual Energy Production per Square Kilometer of Land Area for Wind Resource $\geq$ Class 3, 50-m Hub Height, 10 D by 5D Spacing, 25\% Efficiency, and $25 \%$ Power Losses . . . . . . . . . . . . . . . . .

10 Wind Potential in the Contiguous United States for Four Land Exclusion Scenarios in Units of Average Wind Power Potential in Thousands of Megawatts, Annual Wind Electric Potential in Billions of kWh, and Annual Wind Energy Potential in Quads . . . . . . . .

11 Wind Potential in the Contiguous United States for Four Land Exclusion Scenarios as a Percentage of U.S. 1990 Total Electric Consumption, 1988 Total Energy Consumption, and Projected Total Energy Consumption in the Year 2030 . . . . . . . . . . . .

12 Power Ratios for Various Turbine Spacings in Comparison to That of the $10 \mathrm{D}$ by $5 \mathrm{D}$ Spacing Used in the Estimates of Wind Electric Potential

13 Average Power Intercepted, Average Power Output, and Annual Energy Production per Square Kilometer of Land Area for Wind Resource $\geq$ Class 5, 30-m Hub Height, 10D by 5D Spacing, 25\% Efficiency, and 25\% Power Losses 


\subsection{INTRODUCTION}

A wind energy resource atlas of the United States (Elliott et al. 1987) shows that areas potentially suitable for wind energy applications are dispersed throughout much of the United States. Major wind resource areas in the contiguous United States include much of the Great Plains from northwestern Texas and eastern New Mexico northward to the Dakotas and western Minnesota, the nigh plains of Wyoming and Montana, the Atlantic coast from North Carolina to Maine, the Great Lakes, the Pacific coast from central California to Washington, the Texas Gulf coast, exposed ridge crests in the Appalachians as well as the mountains of the West, and windy corridors that occur in many of the western states, such as the passes in Califormia where thousands of wind turbines are currently operating.

Although the U.S. wind atlas contains maps showing the geographical distribution of the wind resource, the atlas provides neither quantitative estimates of the available windy land area nor the wind electric potential possible from the development of these land areas. The actual installation of wind turbines requires consideration of the availability of land on which to site the turbines. Land availability may be constrained by land-use considerations; for example, land may be unavailable for development because of environmental restrictions or economically valuable agricultural or urban activities.

In support of the preparation of the U.S. Department of Energy's National Energy Strategy, Pacific Northwest Laboratory (PNL) estimated the land area available for wind energy development under various scenarios of land-use restriction and several levels of wind energy resource. This report presents the estimates of land area and resultant wind electric potential developed for four scenarios of land exclusion and describes the data bases and methods used to make the estimates. Estimates of windy 1 and area and wind electric potential were developed not only for the contiguous United States as a whole but also for each of the 48 states in the contiguous United States.

Chapter 2.0 describes the wind resource data used in the study. Gridded map data of the wind resource from the Wind Energy Resource Atlas of the United States (Elliott et al. 1987) were used in developing estimates of total windy 
Tand area for the base-case scenario with no exclusions. Chapter 3.0 describes the methods used to develop a data base of approximate areas where wind energy developments would be restricted by environmental considerations. Environmental exclusion areas include parks, monuments, wilderness areas, ecological preserves, wildlife refuges, and other types of protected natural areas. Chapter 4.0 describes the land-use data that were used in estimating land-use restrictions for various types of land (e.g., forest, agricultural, range, and urban lands). As might be expected, the estimates of land area excluded from wind energy development by certain types of 1 and use are subject to uncertainty (for example, the extent to which agricultural and forest lands could be developed is uncertain). To deal with this uncertainty, we developed estimates of the land area that would be excluded under a "moderate" and a "severe" land-use restriction. Chapter 5.0 describes the effects of the environmental and land-use restrictions on the available windy land area. Estimates of the land area in the contiguous United States with various levels of wind resource are presented for four land exclusion scenarios: 1) no exclusions, 2) environmental exclusions only, 3) moderate land-use exclusions, and 4) severe land-use exclusions. Although maps of the available windy land area in each state are shown for only the scenario with moderate land-use exclusions, tables provide data on each state's land area with various levels of wind resource for each of the four land exclusion scenarios.

Chapter 6.0 presents the results of the wind electric potential estimates developed for the four scenarios of land exclusion. To convert the areal estimates of wind resource to estimates of potential electricity production, it was necessary to specify the wind turbine hub height, spacing, efficiency, and power losses. (Appendix A provides a discussion of the turbine spacing, power loss, and efficiency assumptions used.) The wind electric potential that could be achieved using today's turbine technology (which would be costeffective only in areas with high wind resource, comparable to levels being tapped in California today) is compared to that projected to be available using advanced technology (which would be cost-effective even in areas of moderate wind resource). The wind electric potential is also presented for each state relative to recent estimates of total electric and total energy consumption. 
Appendix $B$ provides estimates of the windy land area and wind energy potential, by state, for a scenario of advanced wind turbine technology (utilizing areas of class 3 or greater wind resource where the annual average wind power density is greater than $300 \mathrm{~W} / \mathrm{m}^{2}$ at $50-\mathrm{m}$ heights) and moderate 1 and-use restrictions. 


\subsection{WIND RESOURCE DATA}

The wind resource data base used here was published in a national wind resource atlas (Elliott et al. 1987). Estimates of the wind resource are expressed in wind power classes, defined in Table 1, ranging from class 1 (the lowest) to class 7 (the highest). A gridded map of the annual average wind energy resource for the contiguous United States is shown in Figure 1.

In the atlas, the annual and seasonal average wind power maps appear in both analyzed and gridded versions. To prepare the gridded maps, the analyzed wind resource maps were divided into grid cells of $1 / 3^{\circ}$ longitude by $1 / 4^{\circ}$ latitude over the contiguous United States. The gridded maps were used to assess the certainty of the wind resource estimates and the areal distribution of the wind resources.

\section{TABLE 1. Classes of Wind Power Density}

\begin{tabular}{|c|c|c|c|c|c|c|}
\hline \multirow[b]{2}{*}{$\begin{array}{c}\text { Wind Power } \\
\text { Class } \\
\end{array}$} & \multicolumn{2}{|c|}{$10 \mathrm{~m}(33 \mathrm{ft})^{(\mathrm{ai})}$} & \multicolumn{2}{|c|}{$30 \mathrm{~m}(98 \mathrm{ft})^{(\mathrm{n})}$} & \multicolumn{2}{|c|}{$50 m(164 t)^{(n)}$} \\
\hline & $\begin{array}{l}\text { Wind Power } \\
\text { Density, W/m² }\end{array}$ & $\begin{array}{l}\text { Speed (t) } \\
\mathrm{m} / \mathrm{s}(\mathrm{mph})\end{array}$ & $\begin{array}{l}\text { Wind Power } \\
\text { Density, W/m }\end{array}$ & $\begin{array}{l}\text { Speod(b), } \\
\mathrm{m} / \mathrm{s}(\mathrm{mph})\end{array}$ & $\begin{array}{l}\text { Wind Power } \\
\text { Density, } \mathrm{W} / \mathrm{m}^{2}\end{array}$ & $\begin{array}{l}\text { Speed } \\
\mathrm{m} / \mathrm{s} \text { (mph) }\end{array}$ \\
\hline & 0 & 0 & 0 & 0 & 0 & 0 \\
\hline & 100 & $4.4 \quad(9.8)$ & 160 & $5.1(11.4)$ & 200 & $5.6(12.5)$ \\
\hline 2 & 150 & $5.1(11.5)$ & 240 & $5.9(13.2)$ & 300 & $6.4(14.3)$ \\
\hline 3 & 200 & $5.6(12.5)$ & 320 & $6.5(14.6)$ & 400 & $7.0(15.7)$ \\
\hline & 250 & $6.0(13.4)$ & 400 & $7.0(15.7)$ & 500 & $7.5(16.8)$ \\
\hline & 300 & $6.4(14.3)$ & 480 & $7.4(16.6)$ & 600 & $8.0(17.9)$ \\
\hline 18.6 & 400 & $\begin{array}{l}7.6(15.7) \\
7.0(15)\end{array}$ & 640 & 8.2 (18.3) & 800 & $8.8(19.7)$ \\
\hline & 1000 & $9.4(21.1)$ & 1600 & $11.0(24.7)$ & 2000 & $11.9(26.6)$ \\
\hline
\end{tabular}

(a) Vertical extrapolation of wind power density and wind speed are based on the 1/7 power law. (b) Mean wind speed is estimated assuming a Rayleigh distribution of wind speeds and standard sea-level air density. The actual mean wind speed may differ from these estimated values by as much as $20 \%$, depending on the actual wind speed distribution and elevation above sea level. 


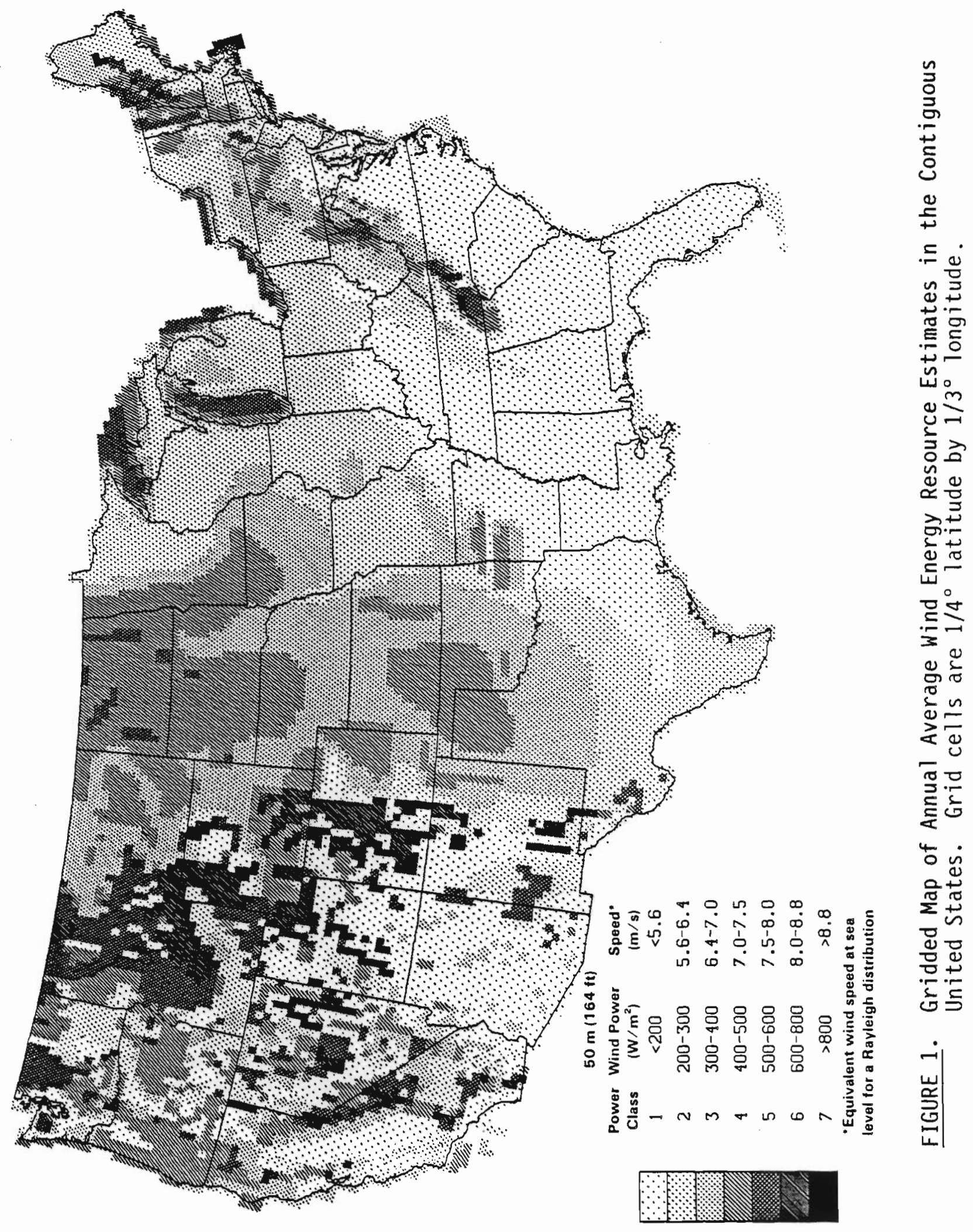


The gridded maps of the wind resource, such as the one in Figure 1 , do not show some of the smaller-scale features that are apparent on the analyzed maps. For this reason, the analyzed wind resource maps show greater detail than the gridded maps, especially in mountainous or coastal areas. However, the gridded maps of the wind resource allow the user to associate the wind power classes for specific grid cells with the certainty rating, percentage of land area estimated to have a given wind power class, and other relevant quantities for those grid cells.

Each wind power class represents a range of mean wind power densities (in units of $W / m^{2}$ ) at specified heights above ground. The wind power density incorporates in a single number the combined effect of the frequency distribution of wind speeds and the dependence of the wind power on air density and on the cube of the wind speed. The estimated mean wind speeds shown with each power class correspond to a Rayleigh distribution of wind speeds at standard sea-level air density. Although the Rayleigh distribution approximates observed wind speed distributions reasonably well in many areas of the contiguous United States, there are many exceptions. The actual mean wind speed may differ from the estimated values in Table 1 by as much as $20 \%$, depending on the actual wind speed distribution and elevation above sea level.

Table 2 shows why the annual average wind speed alone may not be a reliable indicator of the annual average wind power density. Data from the three locations listed indicate that the locations have identical mean wind speeds at $10 \mathrm{~m}(33 \mathrm{ft})$. However, the wind power density, which is based on the frequency distribution of the wind speeds, is substantially different for the three locations, such that each location has a different wind power class. The wind speed distribution for the location in New York is approximated wel1 by a Rayleigh wind speed distribution. The wind speed distributions of the other two locations are not.

Vertical extrapolation of wind speed and wind power density in Table 1 is based on a power law exponent, $a$, of $1 / 7$ using the following equations:

$$
\frac{V_{2}}{V_{1}}=\left(\frac{z_{2}}{z_{1}}\right)^{a} \quad \text { or } \quad \frac{\mathrm{P}_{2}}{\mathrm{P}_{1}}=\left(\frac{\mathrm{z}_{2}}{\mathrm{z}_{1}}\right)^{3 a}
$$


TABLE 2. Comparison of Annual Average Wind Power at Three Sites

With Identical Annual Average Wind Speeds at $10 \mathrm{~m}$

\begin{tabular}{|c|c|c|c|}
\hline Site & $\begin{array}{c}\text { Annual Average } \\
\text { Wind Speed, } \\
\mathrm{m} / \mathrm{s} \text { (mph) } \\
\end{array}$ & $\begin{array}{c}\text { Annual Average } \\
\text { Wind Power Density, } \\
\mathrm{W} / \mathrm{m}^{2} \\
\end{array}$ & $\begin{array}{c}\text { Wind } \\
\text { Power Class }\end{array}$ \\
\hline Culebra, Puerto Rico & $6.3(14)$ & 220 & 4 \\
\hline Tiana Beach, New York & $6.3(14)$ & 285 & 5 \\
\hline San Gorgonio, California & $6.3(14)$ & 365 & 6 \\
\hline
\end{tabular}

where $V_{1,2}$ and $P_{1,2}$ equal the mean wind speed and wind power density at heights $\mathrm{Z}_{1,2}$.

The increase of the mean wind power density with height is reasonably we 11 approximated by the $1 / 7$ power law at many sites (in areas of low roughness and relatively flat terrain), but there are numerous exceptions. In areas of complex terrain and/or high roughness, the wind shear is difficult to estimate with any reasonable degree of certainty. Therefore, it is extremely important to measure the wind resource at heights comparable to wind turbine hub heights, because large errors in a site's estimated wind resource at turbine hub height can occur if the wind resource is extrapolated up from lower heights, such as $10 \mathrm{~m}$. (Hub heights of most existing commercial wind turbines are largely in the range of 18 to $30 \mathrm{~m}$ (60 to $100 \mathrm{ft}$ ) above ground.)

The wind power estimates apply to areas free of local obstructions to the wind and to terrain features that are well exposed to the wind, such as open plains, tablelands, and hilltops. Within mountainous areas, wind resource estimates apply to exposed ridge crests and mountain sumits.

Today's technology allows the exploitation of the wind resource in certain areas with resource class 5 or greater. Most of the successful wind plants in California that are currently being effectively utilized to produce power in a utility grid are located in areas of class 5 or greater wind resource.

In many areas of the United States where wind power increases significantly with height (that is, an increase equal to or greater than that of the $1 / 7$ power, as shown in Table 1 ), raising the hub height to $50 \mathrm{~m}$ could result in at least a $25 \%$ increase in energy capture for an additional cost of only about $8 \%$ (Hock et al. 1990). Data on wind power variation with height 
collected at 38 sites in windy areas throughout the contiguous United States indicate that the mean wind power density at the majority (79\%) of these sites increases with height at a rate equal to or greater than that estimated using the $1 / 7$ power 1 aw (Elliott et al. 1987). In areas where the $1 / 7$ power law applies, a class 3 site with a wind turbine at $50 \mathrm{~m}$ would produce approximately the same wind power as a class 4 site with a wind turbine at $28 \mathrm{~m}$ or a class 5 site with a wind turbine at $18 \mathrm{~m}$.

With projected improvements in the efficiency of advanced wind turbines (from improved airfoils, power electronics, control systems, and so on) and the use of taller towers raising hub heights to $50 \mathrm{~m}$ or higher, class 3 sites could become suitable for wind energy development in the near future. Based on these projections, we have used those grid cells with class 3 or greater resource in Figure 1 in further analyses involving the areal distribution (percentage of land area) and wind electric potential. Grid cells with class 1 or 2 resource are considered unsuitable for wind energy exploitation, at least for commercial-scale utility power generation in the near future, and have been excluded from further analysis.

Because the values for wind power classes shown on the wind resource map in Figure 1 apply only to areas well exposed to the wind, the map area does not indicate the true 1 and area experiencing this power. The fraction of the land area represented by the wind power class shown on the map depends on the physical characteristics of the land-surface form. On a flat open plain, for example, close to $100 \%$ of the area will be in the same wind power class, but in hilly and mountainous areas, the wind power class assigned will only apply to that small proportion of the area that is well exposed. A map of classes of land-surface form by Hammond (1964) provided information on the distribution of plains, tablelands, hills, and mountains in the United States. For each class of land-surface form, the percentage of land area that is representative of the area well exposed to the wind has been estinated. These percentages were determined subjectively as a function of the slope, local relief, and profile type specified by Hammond.

Figure 2 shows the areal distribution (expressed as a percentage of a grid cell's total land area) in the contiguous United States for grid cells in which the annual average wind power is class 3 or greater. Grid cells where 


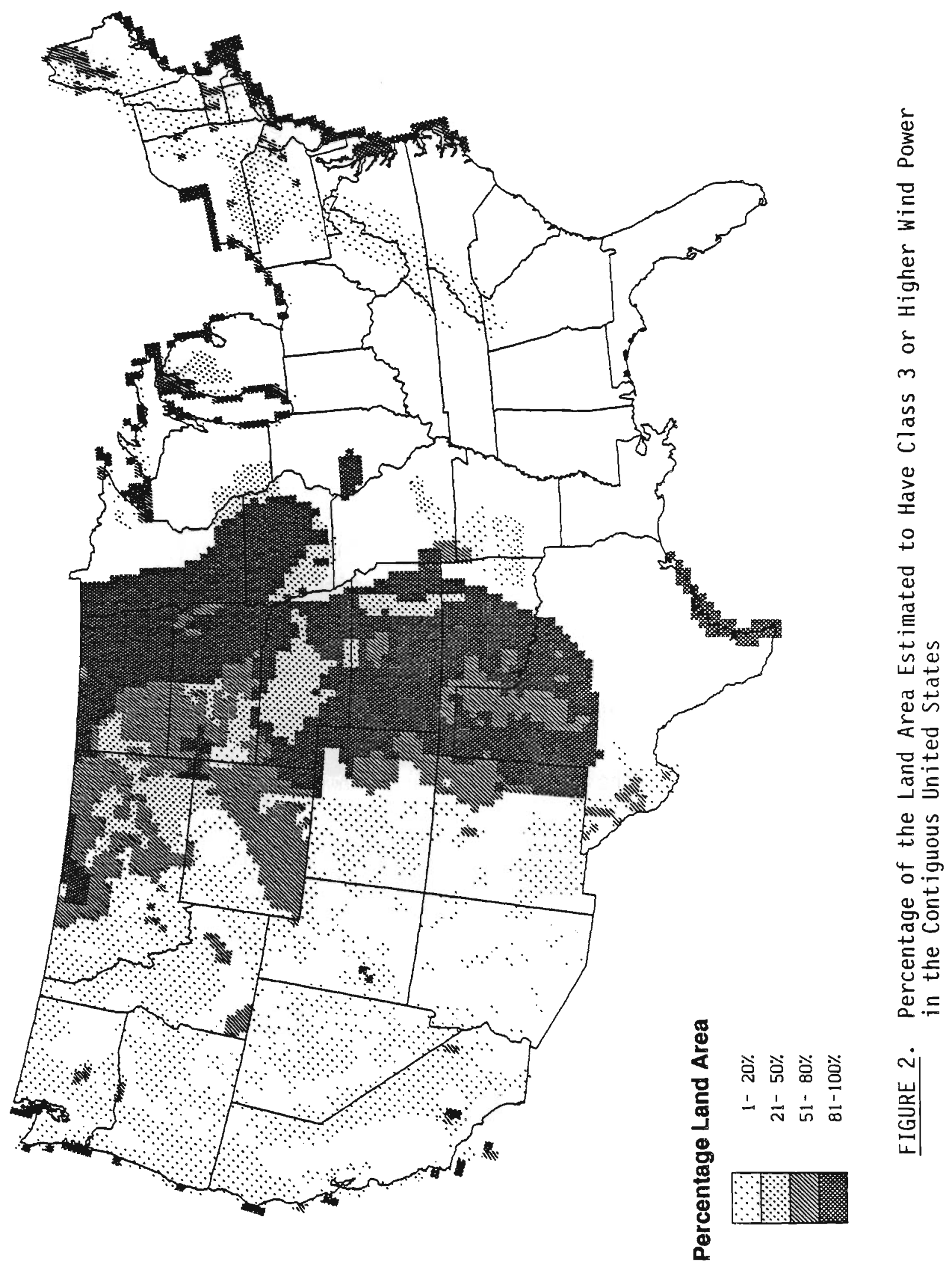


$80 \%$ or more of the total land area has class 3 or greater power are mostly located in areas of relatively flat terrain, such as much of the southern and northern Great Plains, coastal areas of Texas, and areas along the Northeast coast and Great Lakes. Hilly areas within the Great Plains, such as the Sand Hills in Nebraska and the Flint Hills in Kansas, are apparent in Figure 2 as areas where generally only 21 to $50 \%$ of the land area is well exposed to the wind. Throughout the Appalachians and mountainous areas in the West, suitable wind resource only exists on a sinall fraction (1 to 20\%) of the land area. In many mountainous areas, only about 2 to $5 \%$ of the total land area is estimated to be well exposed. The isolated grid cells scattered in California, Oregon, Washington, and Montana that have class 3 or greater power for more than $20 \%$ of the 1 and area in the cell represent windy coastal strips or islands in the coastal areas and wind corridors in the inland areas (such as San Gorgonio Pass in California, the Columbia River and Ellensburg corridors in Oregon and Washington, and the Whitehall and Livingston corridors in Montana). Over 50\% of the land area in much of southern and central Wyoming and the plains in northwestern Montana has class 3 or greater annual average wind power.

The areal distribution data do not account for environmental or 1 and-use restrictions; that is, any reduction in the fraction of a grid cell's land available for wind energy development was solely a result of terrain interfering with the exposure of potential turbine installations. This areal distribution data base was used as a starting point (base case) for calculating the land areas that would be affected by the environmental and 1 and-use exclusions.

The data on environmental and land-use restrictions were obtained from several sources and in some cases required modification to mesh with the wind energy resource data. We chose several scenarios for estimating the effects of differing levels of land exclusion. Exclusions under these scenarios are discussed in Chapters 3.0 and 4.0 on environmental and land-use restrictions, respectively. 


\subsection{ENVIRONMENTAL EXCLUSIONS}

Environmental exclusion areas, as defined here, largely represent natural areas including parks, monuments, wilderness areas, ecological preserves, and wildlife refuges (as well as some other type of natural areas) where industrial, commercial, and residential developments are restricted or very 1 imited. Although no suitable data base with these environmental areas was available in digital form, national maps were obtained that depicted the locations of federally administered environmental areas. Additional environmental areas are administered by state and private agencies. In examining maps showing the geographical distribution of environmental areas, we recognized that these areas are most concentrated in mountainous and coastal regions. In mountainous regions, the amount of land area occupied by environmental areas generally increases with the ruggedness of the terrain and the local relief. We observed that the distribution and extent of enviromental areas are generally correlated with the classes of land-surface form that were already in our gridded data base. For each class of land-surface form, a rough estimate of the percentage of land area to be excluded for environmental reasons was inferred from a comparison of the maps of the federally administered environmental areas with the maps of land-surface form. The exciusion values assigned to each land-surface form are shown for noncoastal areas in Figure 3 .

On average, the percentage of area occupied by federally administered environmental lands is probably somewhat less than the exclusion percentages assigned. However, we tried to be conservative in our exclusion estimates to account for other lands that might be excluded for environmental reasons, such as environmental lands administered by state and private agencies, and proposed environmental 1 ands.

A minimum exclusion of $10 \%$ was assigned to land-surface forms that, on average, contain only a small fraction of environmentally designated lands. We realize that in a few specific regions, such as flatter regions that contain some large environmentally designated land areas, our estimate of the environmental land exclusion area may be significantly less than the actual; however, in most regions our estimate of the environmental exclusion area is probably much greater than the actual. 


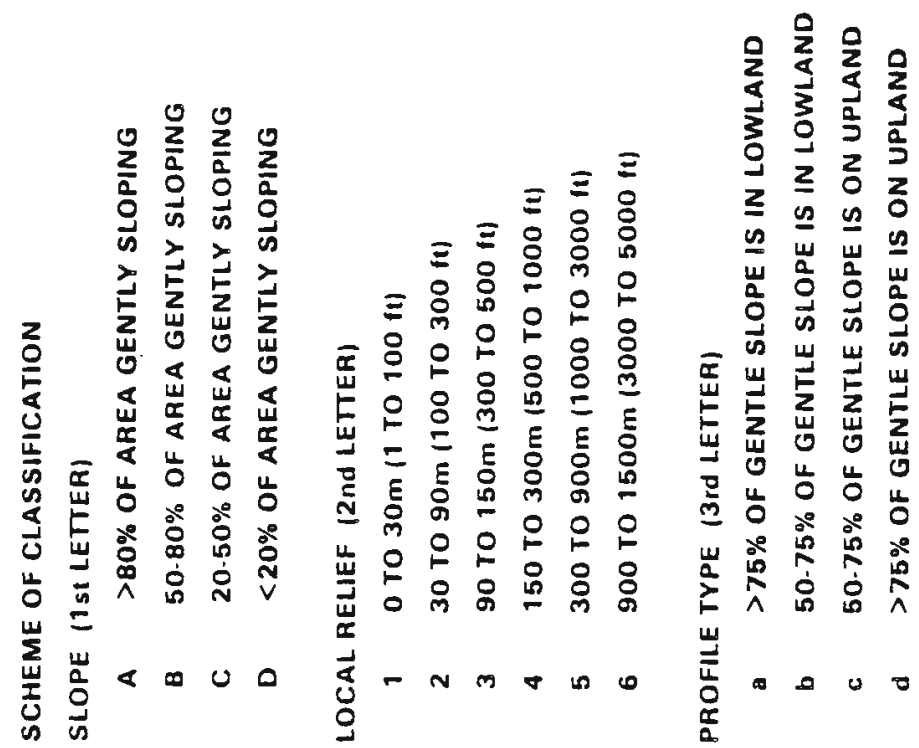

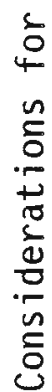

ธง

웡

袰

후

눙

응

은

을 온
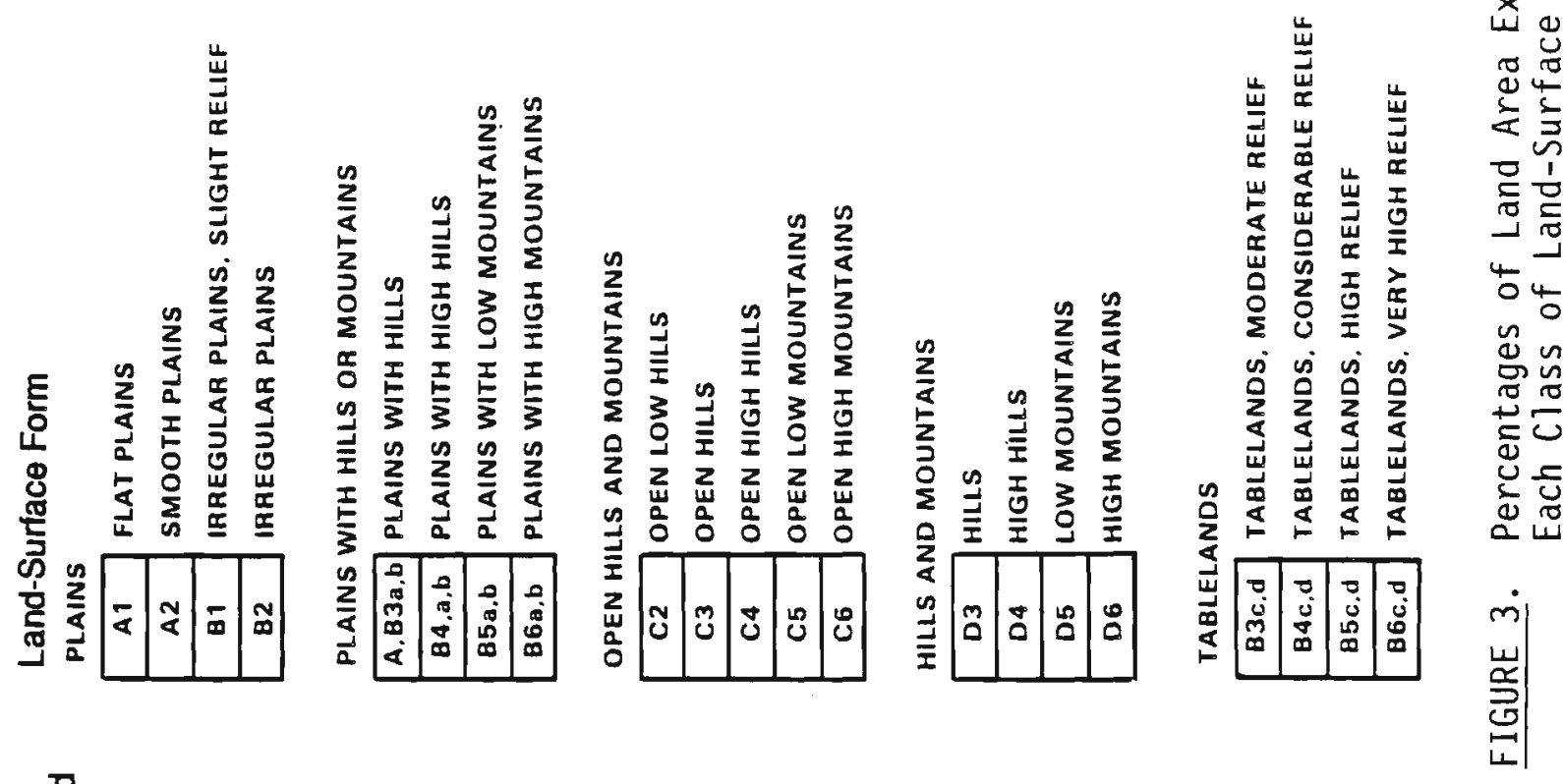

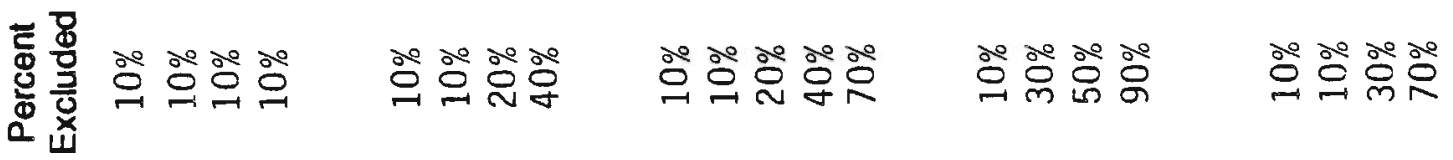


In all coastal areas, at least $50 \%$ of the land area was excluded (as opposed to $10 \%$ for inland areas) because it was recognized that coastal areas generally have a higher concentration of environmental areas (e.g., national wildlife refuges, national seashores, and state parks) and recreation areas (e.g., beach resorts) where industrial development would be restricted. These coastal areas include the coasts and coastal islands of the Atlantic and Pacific Oceans, the Gulf of Mexico, the Great Lakes, and seven other large lakes. The $50 \%$ exclusion was applied to grid cells in which coastal water was at least $1 \%$ of the grid cel1's total area.

A map of the approximated environmental exclusion areas is shown in Figure 4. The 90\% exclusion areas are the most. rugged mountainous regions of the west, where local relief exceeds $3000 \mathrm{ft}$. The large exclusion in the high mountains of the West accounts not only for environmentally designated areas but also for the inaccessibility of the high mountains because of the steep terrain and heavy snow in the winter season. The mountains throughout the Great Basin Plateau, such those in Nevada where 30 to $40 \%$ of the land area was excluded, have fewer environmental areas and are more accessible than the more rugged mountains of the Rockies, Cascades, and Sierras. In the Appalachians, the exclusion areas range from $20 \%$ in the hilly areas to $50 \%$ in the most mountainous areas. Deep canyons, as well as mountains, are also accounted for in the environmental exclusion areas. The Grand canyon is largely included in the $70 \%$ exclusion area in northwestern Arizona. The $10 \%$ exclusion areas represent flatter regions where, for the most part, environmental areas occupy only a small fraction of the total land area.

Special care was taken not to exclude known wind corridors that exist at relatively low elevations within the mountainous regions, such as the wind corridors in California, Montana, and Washington. The wind corridor areas were identified and assigned the minimal 10\% exclusion. 


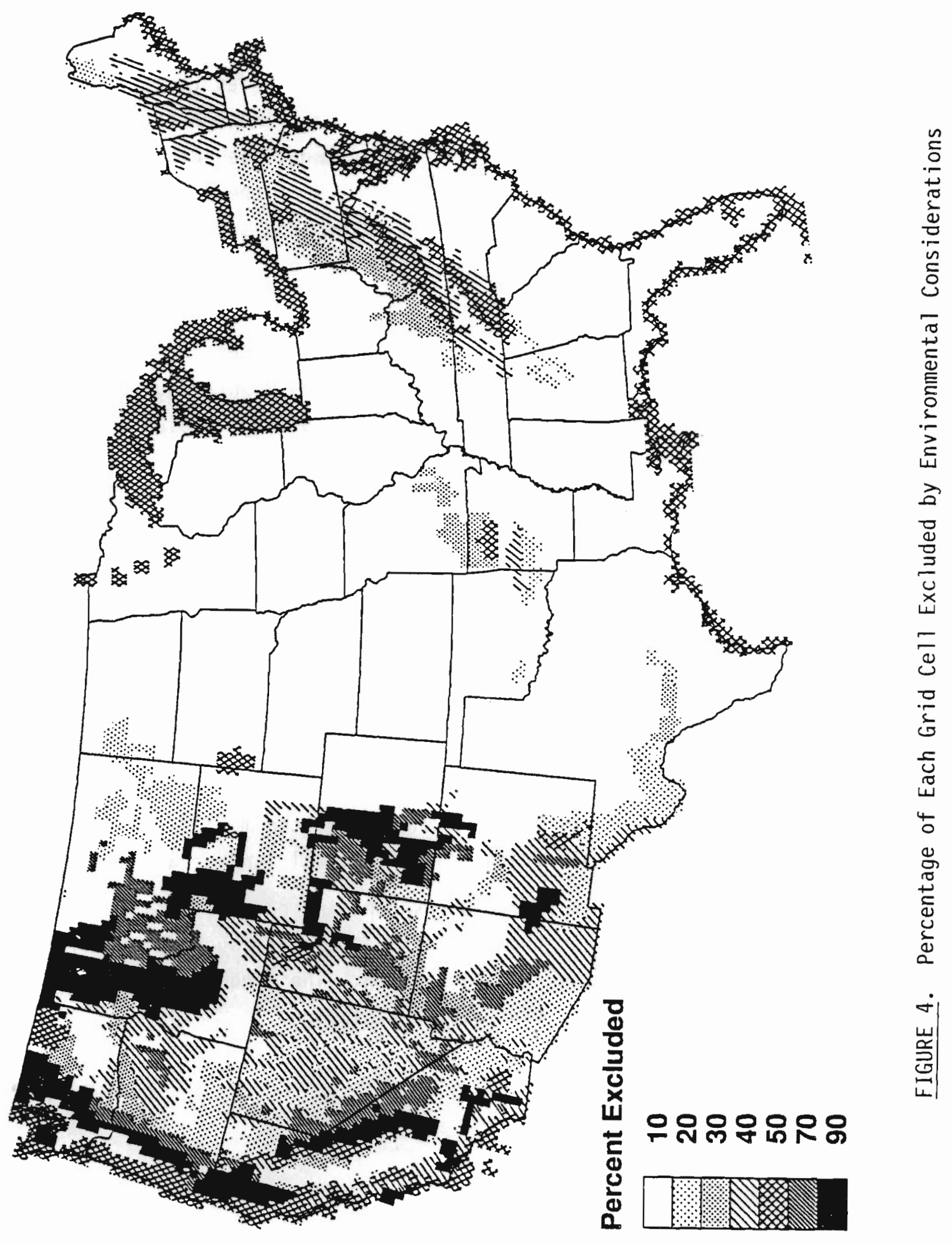




\subsection{LAND-USE EXCLUSIONS}

For estimating land-use exclusion areas, we obtained a suitable land-use data base in digital form that was developed by the U.S. Environmental Protection Agency (EPA), Las Vegas. This land-use data base inciuded the percentage of each grid element associated with each of the 11 land-use types: 1) agricultural 1and; 2) range land; 3) mixed agricultural and range 1 and; 4) deciduous forest; 5) coniferous forest; 6) mixed forest; 7) urban 1and; 8) barren 1and; 9) nonforested wetland, 10) water; and 11) open, low scrub land. The land-use data were for grid cells of $1 / 6^{\circ}$ latitude by $1 / 4^{\circ}$ longitude, whereas PNL's wind resource grid cel1s were for $1 / 4^{\circ}$ latitude by $1 / 3^{\circ}$ longitude. We converted the land-use data base to the PNL grid cell format.

Maps showing the geographical distribution of each land-use type are shown in Figure 5. Forest, agricultural, and range lands combined account for the vast majority of the land area in the contiguous United States. Moreover, in any given state, at least one of these three major land-use types-forest, agricultural, or range--accounts for the majority of the state's land area. The other land-use types (excluding water) account for only a sma11 fraction of the total land area of the United States.

Major areas occupied by water were excluded from the wind energy base case even before environmental and land-use restrictions are taken into account. For example, the map of class 3 and higher wind power areas in Figure 2 excludes major water bodies, such as coastal waters (i.e., bays, inlets, harbors, and sounds, as well as offshore areas) and major lakes (i.e., the Great Lakes and seven other large lakes). One element in our wind resource data base specified the percentage of each grid cell's area that is land, for grid cells over these coastal areas or major lakes.

To identify areas of water to be excluded, we initially attempted to use the water data derived from the EPA-developed land-use data base, which included inland water areas not in the PNL-developed data base. However, we found that some grid cells containing major coastal lands and islands (e.g., Block Island, Rhode Island; Nantucket Island, Martha's Vineyard, and a large fraction of Cape Cod, Massachusetts, as well as some significant land areas in other coastal regions of the United States) were classified as water. 


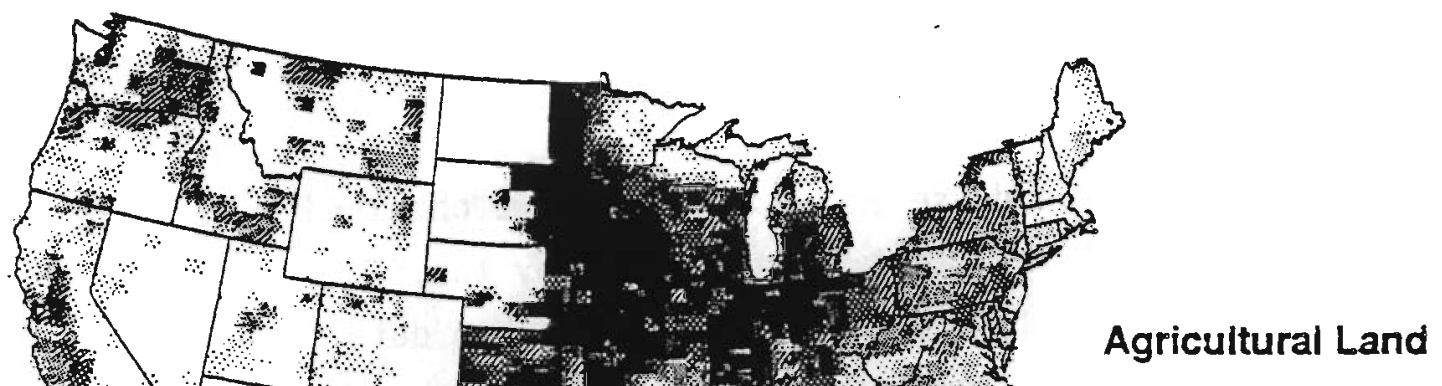

Percent
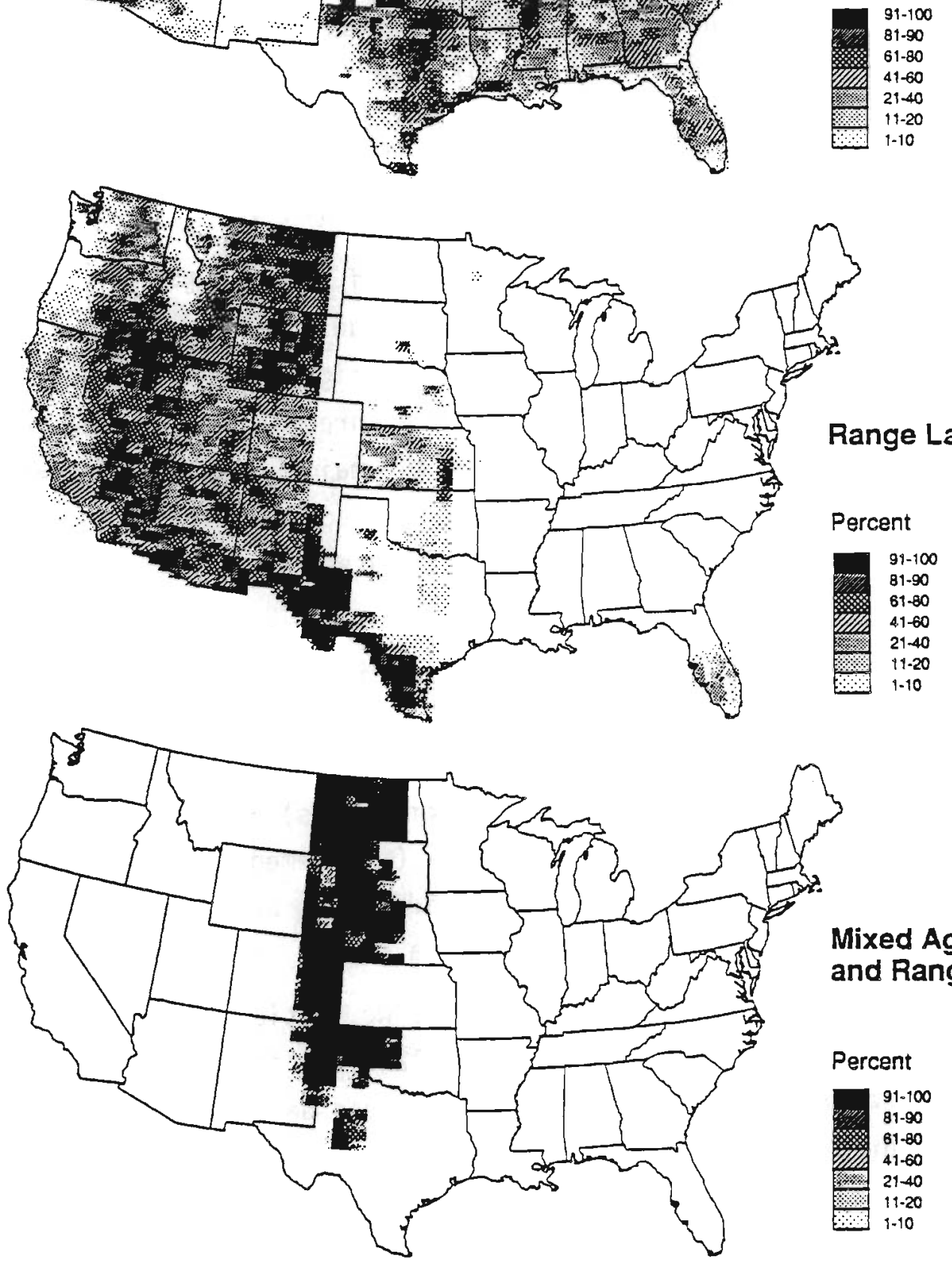

FIGURE 5. Maps of Land-Use Type from the Gridded Data Base 

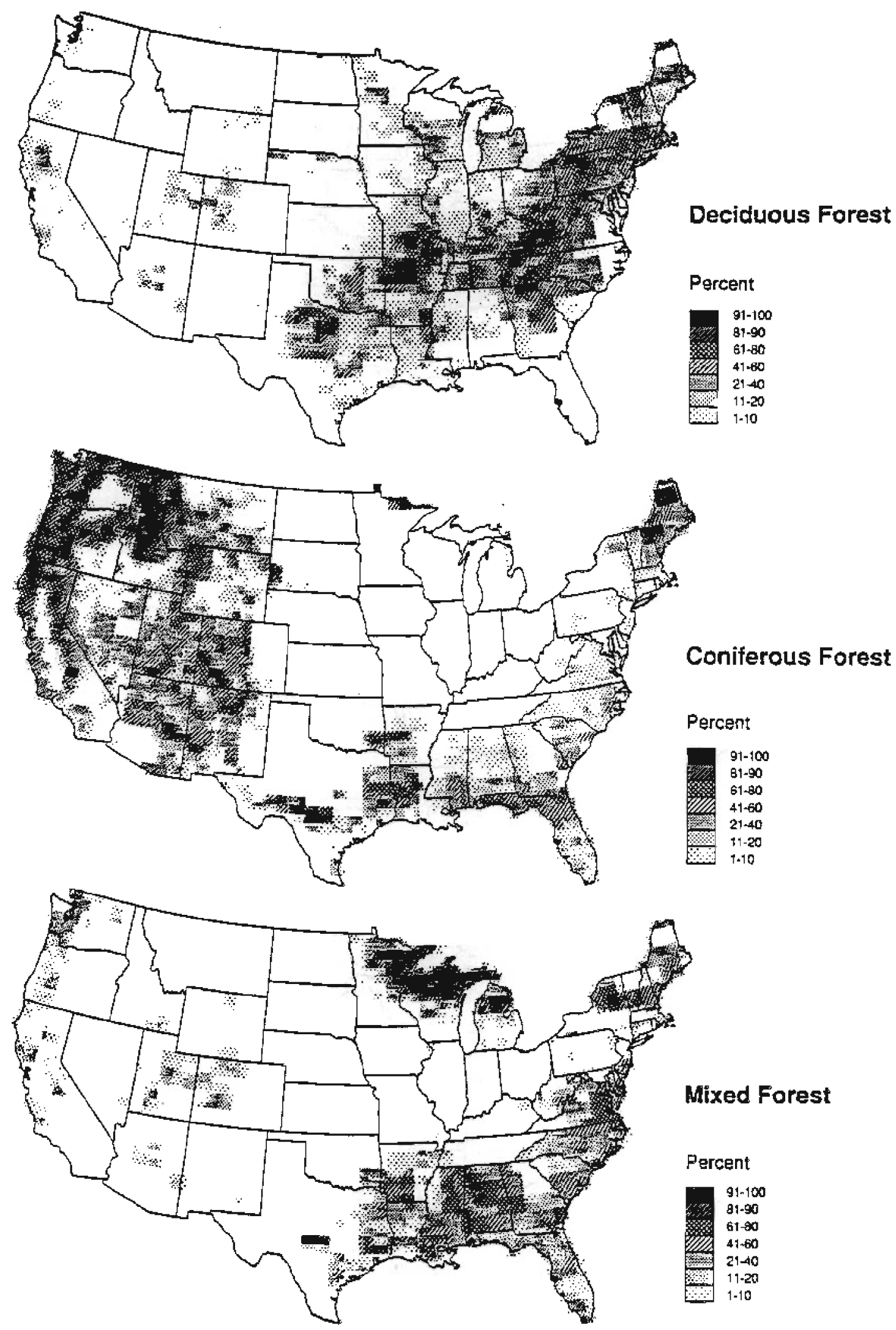

FIGURE 5. (contd) 

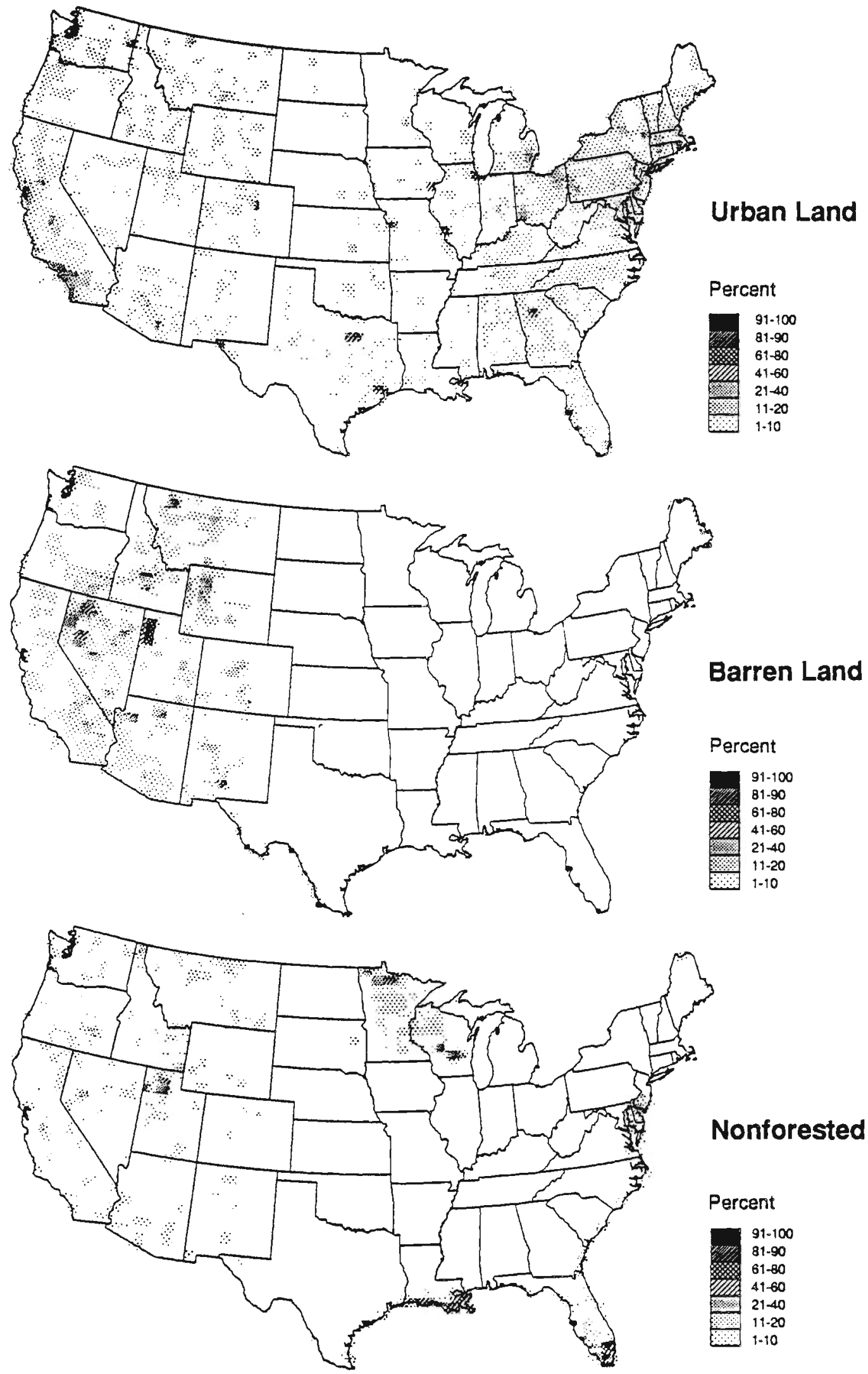

FIGURE 5. (contd) 

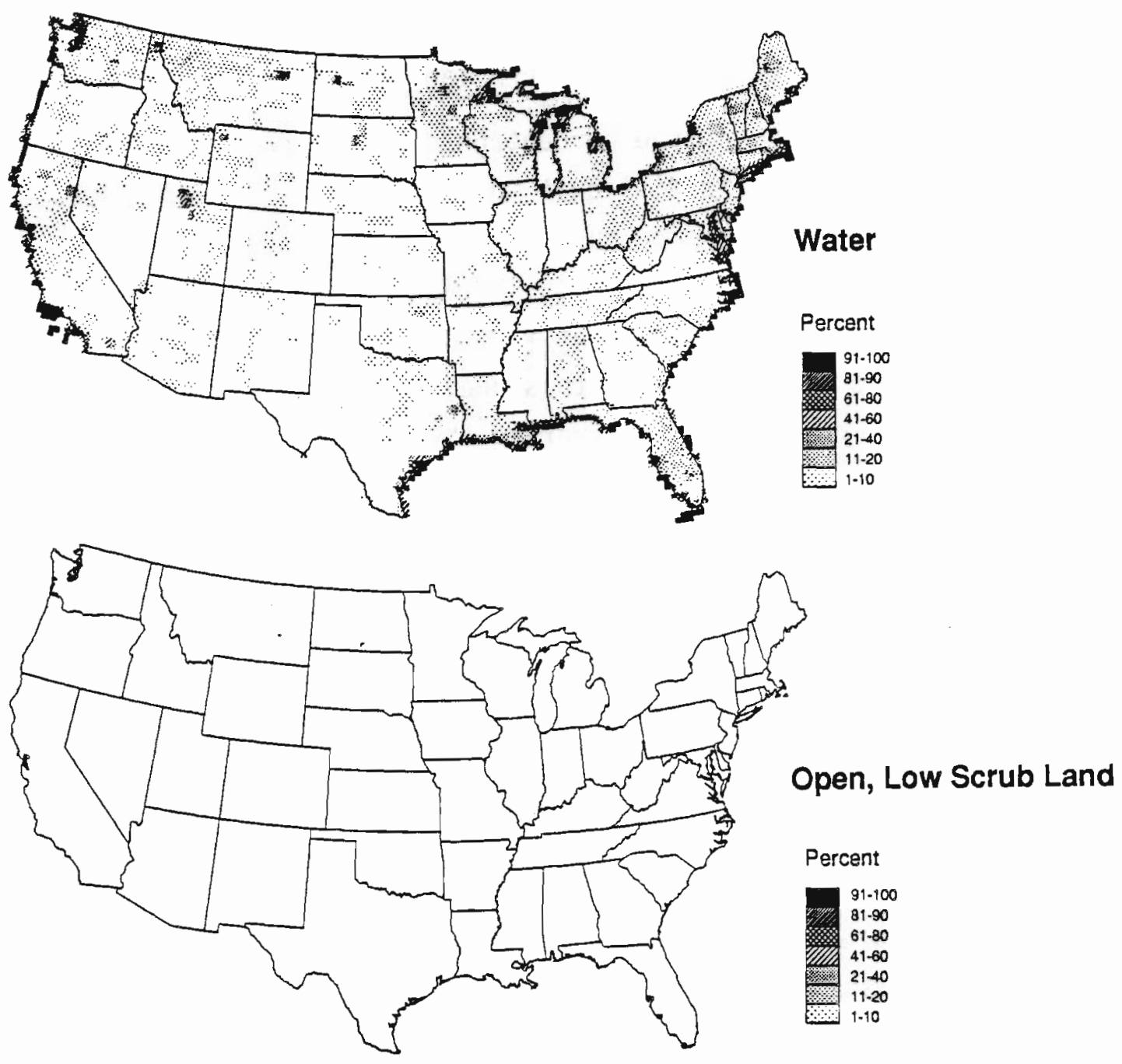

FIGURE 5. (contd) 
To exclude these coastal land areas would have a substantial impact on the areal wind resource estimates, especially for states where a large fraction of the wind resource potential is from coastal lands. For this reason, we did not use the water data from the EPA land-use data base.

As might be expected, the percentage of the land area to be excluded from wind energy development is difficult to estimate for certain types of land use and vary widely, depending on the assumptions made. The greatest uncertainty concerned how to treat forest, agricultural, and mixed agricultural/ range lands, which together account for a large fraction of the land area in the United States. To deal with this uncertainty, we created several land-use exclusion scenarios, in which we varied the percentage of the Iand area excluded for these three land-use types, to evaluate what effect the different exclusions would have on the areal estimates for a given state or the United States. For this report, we will describe two of these scenarios--a "moderate" and a "severe" land-use restriction.

Table 3 shows, for each land-use type, the percentage of land area excluded under the moderate and severe land-use restrictions. The only differences between the moderate and severe land-use restrictions occur with the forest, agricultural, and mixed agricultural/range lands. For simplicity, we have combined the three original forest land-use types (deciduous, coniferous, and mixed) into a single category called "forest". The low, open scrub land-use type has been omitted from Table 3, because no lands were classified as this type in the contiguous United States (see Figure 5). Lands that could possibly have been classified as low, open scrub land were apparently classified as range or barren land. For example, the desert scrub land in southeastern California, including the Mojave Desert, is largely classified as range land.

The land-use types in Table 3 are listed in approximate order by total land area in the contiguous United States, with forest lands occupying the largest area and urban lands the smallest area. The first four land-use types combined represent more than $90 \%$ of the total 1 and area of the contiguous United States. Therefore, specification of the percentage of 1 and area excluded for these four land-use types has the greatest impact on the areal wind resource estimates. The other three land-use types (barren, wetland, 
TABLE 3. Percentage of Land Area Excluded Under Moderate and Severe Land-Use Restrictions for Each Land-Use Type

\begin{tabular}{l}
\multicolumn{1}{c}{$\begin{array}{c}\text { Land-Use } \\
\text { Type }\end{array}$} \\
\hline Forest \\
Agriculture \\
Range \\
Mixed Ag./Range \\
Barren \\
Wetland \\
Urban
\end{tabular}

\section{Percentage of Land Excluded Moderate $\quad$ Severe}

$\begin{array}{rr}50 & 100 \\ 30 & 100 \\ 10 & 10 \\ 20 & 55 \\ 10 & 10 \\ 100 & 100 \\ 100 & 100\end{array}$

and urban) account for only a relatively small percentage of the contiguous U.S. 1 and area, so that varying the exclusion percentages for these lands has only a relatively minor impact on the areal wind resource estimates.

For urban 1 and and wetland, $100 \%$ of the land area was excluded under both moderate and severe land-use restrictions, because we believe that wind energy development in these areas is unlikely.

For range land and barren 1 and, we do not see any conflicts with wind energy development, given that wind farms have successfully been located in these types of land-use areas in California. However, we have excluded $10 \%$ of these 1 and areas to account for land that may be occupied by roads and structures.

For agricultural lands, we have excluded $30 \%$ of the land area under the moderate 1 and-use restriction and $100 \%$ of the land area under the severe 1 anduse restriction. A $30 \%$ exclusion was considered to be realistic under the moderate 1 and-use restriction for the following reasons:

1. Wind energy development would occupy no more than about $10 \%$ of the available land area, so that most of the 1 and area would still be available for agricultural uses.

2. The exclusion issue could depend more on economics than on anything else in the agricultural areas; if farmers receive compensation for the use of their land to the extent that their earnings are significantly greater for energy production than for crop production, then they may be more than willing to give up some land for energy production while still retaining much of it for crop production. 
3. With this optimistic scenario, we have assumed that $80 \%$ of all agricultural land (in windy areas) will be available, but that about $10 \%$ of the available land is excluded to allow for existing structures and roads.

Under the severe land-use restriction, where $100 \%$ of the agricultural land would be excluded from wind energy development, the wind resource potential would be drastically reduced in many states in the Midwest and Great Plains agricultural belts. For example, Iowa would 1ose more than $90 \%$ of its wind resource potential, because agricultural lands make up over $90 \%$ of the state's windy land area.

For the mixed agricultural and range land-use type, we have assumed that these lands are 50\% agricultural and 50\% range lands. Therefore, we took the average of the percentage of land area excluded for the separate agricultural and range lands, resulting in a $20 \%$ exclusion under the moderate land-use restriction and a 55\% exclusion under the severe land-use restriction. The mixed agricultural and range lands include much of the Great Plains region that extends from northwestern Texas northward to North Dakota.

For forest lands, we have excluded $50 \%$ and $100 \%$ of the land area under the moderate and severe land-use restrictions, respectively. We selected a $50 \%$ exclusion under the moderate land-use restriction for several reasons. First, although forest lands cover much of the eastern United States, in nonmountainous terrain they are predominantly in low wind resource areas (class 1 and 2). Because we are only concerned with areal estimates for areas of class 3 and higher, our focus is primarily on the forested mountain regions, where the highest wind resources are located on the ridge crests. Trees on exposed ridge crests are quite often smaller and more scattered than those on the slopes and in the valleys. In fact, well-exposed ridge crests in some forested regions are nearly devoid of trees. On ridges where the trees are relatively small (i.e., no taller than about $10 \mathrm{~m}$ ), it may not be necessary to remove many trees if relatively tall towers (e.g., 50-m towers) are used, such that the wind turbine rotor disks are substantially above the trees. Thus, from this perspective, it appears reasonable to include much of the land area associated with windy ridge crests in forested lands that could be utilized for wind energy development without significant removal of existing 
trees. (We emphasize that, in mountainous terrain, the land area represented by ridge crests is typically only about $5 \%$ of the total land area.)

However, sone forests are located in nonmountainous terrain (e.g., in areas of hills or tablelands) that is still estimated to have a class 3 or higher resource, such as forested areas in western Texas, central 0klahona, southwestern Wisconsin, northern Michigan, and the northeastern states. In these areas, hilltops and uplands with good exposure to winds are likely to have good wind resource, but the wind resource is diminished significantly near or downwind from groves of trees unless the trees are relatively small in comparison to the turbine height. To exclude a larger fraction of the forest land that is located on exposed terrain in nonmountainous areas is impractical because of geographical variations in the height and density of the trees (e.g., the trees in western Texas are substantially smaller and more scattered than those in northern Michigan).

To more adequately address the exclusion of forested areas, data on the height and density of the trees would be useful, but this information is not available in our current data base. Therefore, after considering all types of terrain and the variability of the height and density of trees in the different regions and at different elevations, we have elected to exclude $50 \%$ of the forest lands under the moderate land-use restriction and $100 \%$ under the severe 1 and-use restriction.

We performed an analysis to examine what happens to the areal estimates of wind resource for three different exclusions of forest 1 ands: $0 \%, 50 \%$, and $100 \%$. When the forest exclusion is increased from $0 \%$ to $50 \%$ or $100 \%$, the U.S. land area with class 3 and greater is reduced by about $8 \%$ or $14 \%$. This small reduction in land area occurs because only a small fraction of the windy land area of the United States is forest 1and, since most of the forest 1 and is located in areas of low wind resource (class 1 and 2). However, if we exclude $100 \%$ of the forest 1 and, the windy 1 and area is severely reduced in many of the eastern states, where large parts of the high wind resource areas are ridge crests in the Appalachians. For example, excluding all forest land eliminates about $90 \%$ of the windy 1 and in West Virginia, where the high wind resource areas are ridge crests located in mountainous terrain that is largely forested. Under the moderate land-use restriction, where $50 \%$ of forest Tand 
is excluded, west Virginia would lose approximately half its windy land area. (This exclusion does not account for the additional land area that would be excluded by environmental considerations.) 


\subsection{ESTIMATES OF WINDY LAND AREA}

The environmental exclusions and land-use exclusion categories were applied in a number of combinations to evaluate the effect on the amount of available land in the contiguous United States at each power class level. For a given wind power class, the available windy land area in a grid cell may be calculated by

$$
A_{W}=A T f_{p}\left(1-f_{E}\right)(1-f L)
$$

where $A_{T}=$ total 1 and area in the grid cell

$f_{p}=$ fraction of the grid cell area in the specified wind power class

$f_{E}=$ fraction of the grid cell area excluded by environmental considerations

$f_{L}=$ fraction of the grid cell area excluded by 7 and-use considerations.

The value of AT depends on the latitude and the percentage of the grid cell that is 1 and and within the state boundary. The value of $f_{p}$ depends on the wind power class and the land-surface form. The environmental exclusion, $f_{E}$, was approximated using data on land-surface form. The value of $f_{L}$ depends on the land-use types and the exclusion scenario that is specified (for example, moderate or severe land-use restrictions).

The windy land area in a state is calculated by summing Aw for all grid cells in the state, for each designated power class.

For the purpose of this report, we have chosen four land exclusion scenarios for comparison and summarize the results for the contiguous United States in Figure 6 and Table 4. The land area estimates by power class are given for each state in Tables 5 through 8 for the four land exclusion scenarios. The values of wind power density in $\mathrm{W} / \mathrm{m}^{2}$ that are given for each wind power class in Figure 6 represent the median values for the 30 - and $50-\mathrm{m}$ heights (see Table 1 for the range of wind power density values in each power class). To put the areas into perspective, we have included a representation of equivalent state land areas in Figure 6, as well as the percentage of the contiguous U.S. land area. 


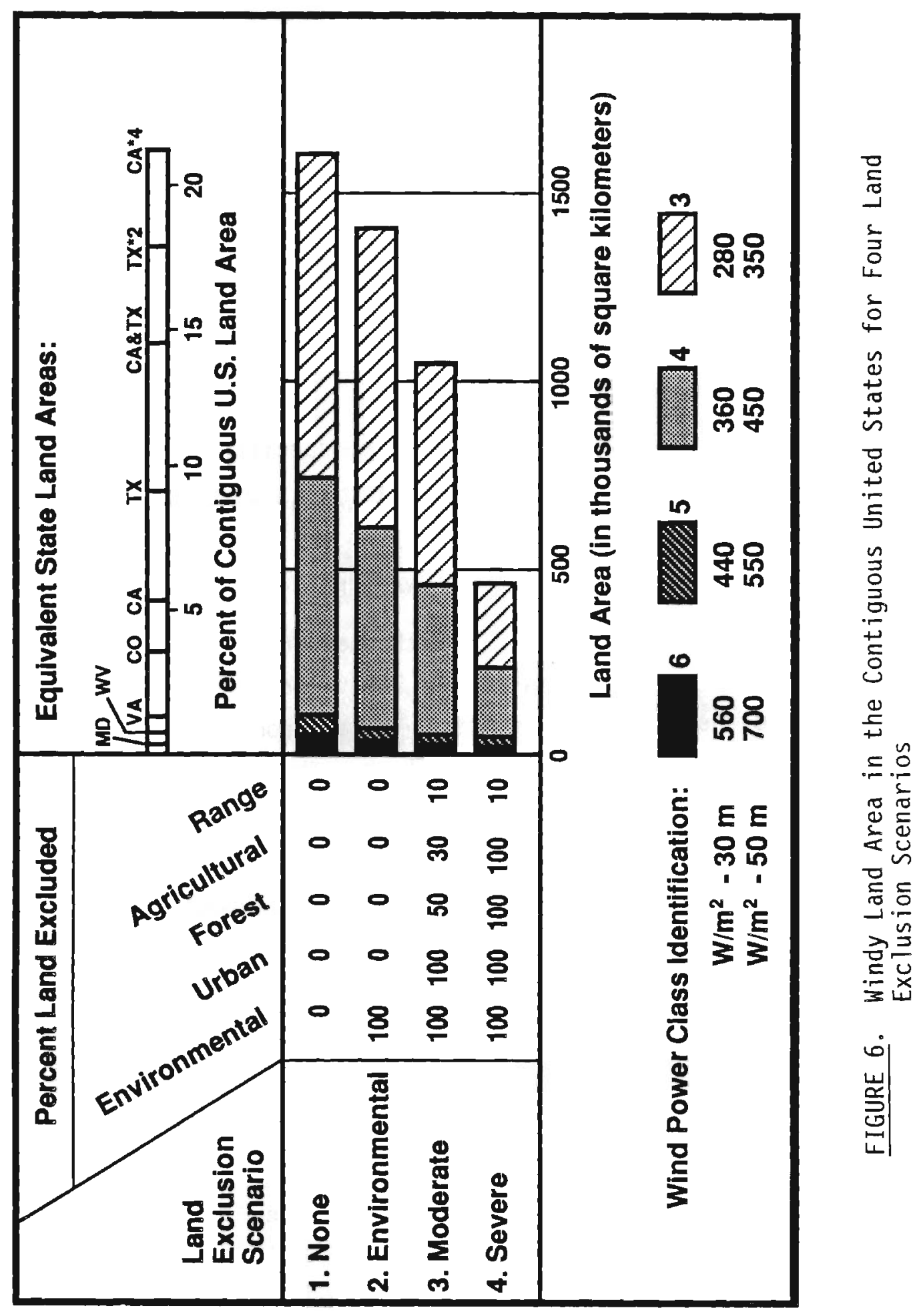



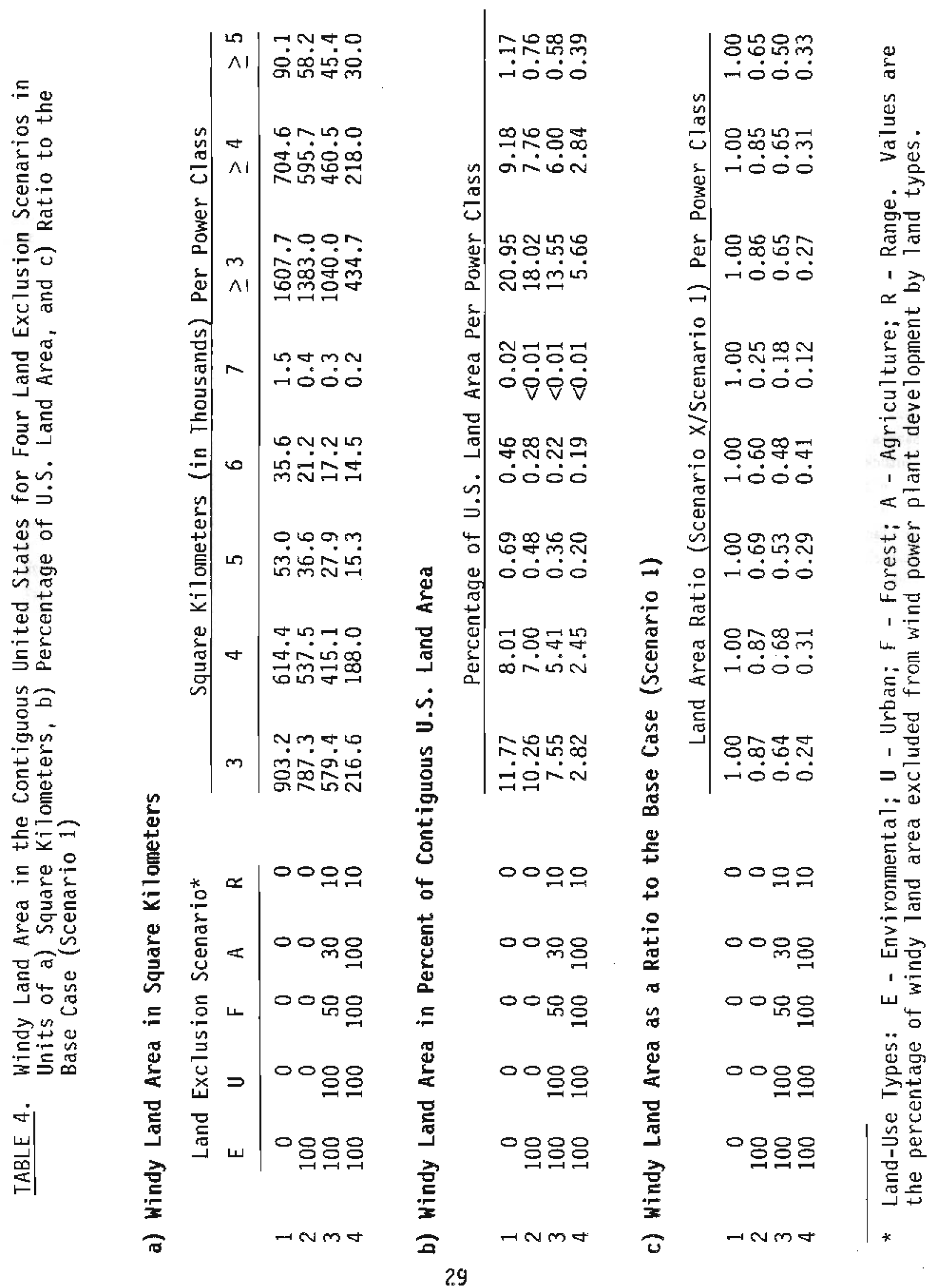
TABLE 5. State Land Area by Power Class for Land Exclusion Scenario 1 (No Exclusions)

\begin{tabular}{|c|c|c|c|c|c|}
\hline \multirow[t]{2}{*}{ State } & \multicolumn{5}{|c|}{ Square Kilometers per Power Class } \\
\hline & 3 & 4 & 5 & 6 & 7 \\
\hline Alabama & 6 & 0 & $\theta$ & $\theta$ & \\
\hline Arizona & 1,119 & 311 & 571 & 57 & $\theta$ \\
\hline Arkansas & 4,897 & 642 & 62 & $\theta$ & $\theta$ \\
\hline California & 6,670 & 3,752 & 1,777 & 2,145 & 104 \\
\hline Colorado & 28,472 & 34,853 & 178 & 3,408 & 376 \\
\hline Connecticut & 1,635 & 99 & 8 & $\theta$ & 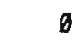 \\
\hline Delaware & 657 & 32 & 8 & $g$ & \\
\hline Florida & 6 & $\theta$ & $\theta$ & ø & \\
\hline Georgia & 168 & 253 & 22 & 9 & $\theta$ \\
\hline Idaho & 7,284 & 2,881 & 3,375 & 1,259 & 180 \\
\hline Illinois & 11,296 & 22 & 6 & $\theta$ & \\
\hline Ind i ana & 6 & 70 & $\emptyset$ & 0 & \\
\hline Iowa & 68,520 & 23,868 & ஏ & 0 & \\
\hline Kansas & 113,949 & 49,506 & 0 & 6 & \\
\hline Kentucky & 111 & 12 & $\theta$ & 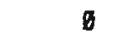 & \\
\hline Lou is iana & g & 6 & $\theta$ & $\emptyset$ & \\
\hline Maine & 10,855 & 1,172 & 472 & 175 & 13 \\
\hline Naryland & 894 & 129 & 11 & $\emptyset$ & \\
\hline Massachusetts & 4,732 & 339 & 634 & 265 & \\
\hline Michigan & 13,960 & 1,407 & 567 & $\theta$ & \\
\hline Minnesota & 34,962 & 63,775 & $\theta$ & 0 & \\
\hline Mississippi & 6 & $\emptyset$ & 6 & $\theta$ & \\
\hline Missouri & 10,707 & 0 & 6 & $\theta$ & \\
\hline Montana & 74,795 & 46,719 & 11,376 & 4,529 & 164 \\
\hline Nebraska & 161,771 & 29,585 & $\theta$ & $\theta$ & \\
\hline Nevada & 1,877 & 2,379 & 2,017 & 1,432 & 137 \\
\hline New Hampshire & 341 & 342 & 395 & 89 & \\
\hline New Jersey & 2,461 & 237 & 0 & $\emptyset$ & \\
\hline New Mexico & 56,965 & 5,733 & 738 & 1,312 & 13 \\
\hline New York & 13,298 & 2,182 & 174 & 14 & \\
\hline North Carolina & 1,681 & 236 & 460 & 132 & \\
\hline North Dakota & 880 & 120,255 & 22,479 & 6 & \\
\hline Ohio & 843 & 278 & 0 & $\emptyset$ & \\
\hline Ok Iahoma & 77,127 & 36,015 & 10 & 6 & \\
\hline Oregon & 1,696 & 7,842 & 949 & 83 & \\
\hline Pennsylvania & 7,961 & 3,368 & 88 & $\emptyset$ & \\
\hline Rhode Is I and & 204 & 31 & $\theta$ & $\emptyset$ & \\
\hline South Carolina & 98 & 40 & 4 & 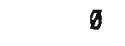 & \\
\hline South Dakota & 39,848 & 97,094 & 1,366 & 3 & \\
\hline Tennessee & 223 & 199 & 60 & 36 & \\
\hline Texas & 151,216 & 39,652 & 413 & 116 & \\
\hline Utah & 1,639 & 645 & 567 & 2,120 & 18 \\
\hline Vermont & 244 & 438 & 413 & 40 & \\
\hline Virginia & 2,810 & 562 & 165 & 6 & \\
\hline Washington & 1,588 & 3,048 & 2,814 & 276 & \\
\hline Mest Virginia & 846 & 523 & 238 & 20 & \\
\hline Wisconsin & 11,153 & 850 & 127 & $\theta$ & \\
\hline Wyoming & 35,844 & 34,615 & 646 & 18,105 & 25 \\
\hline Total & 963,175 & 614,419 & 53,624 & 35,616 & 1,498 \\
\hline
\end{tabular}

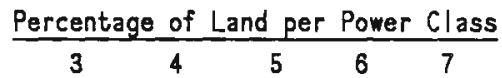

Total

Land, $\mathrm{km}^{2}$

$\begin{array}{llllll}0.0 & 0.0 & 0.0 & 0.0 & 0.0 & 131,487\end{array}$

$\begin{array}{llllll}0.4 & 0.1 & 0.2 & 0.0 & 0.0 & 293,986\end{array}$

$\begin{array}{llllll}3.6 & 0.5 & 0.1 & 0.0 & 0.0 & 134,883\end{array}$

$\begin{array}{llllll}1.6 & 0.9 & 0.4 & 0.5 & 0.0 & 404,815\end{array}$

$\begin{array}{llllll}10.6 & 13.0 & 0.1 & 1.3 & 0.1 & 268,311\end{array}$

$\begin{array}{llllll}8.2 & 0.8 & 0.1 & 0.0 & 0.0 & 12,618\end{array}$

$\begin{array}{llllll}13.1 & 0.7 & 0.0 & 0.0 & 0.0 & 5,005\end{array}$

$\begin{array}{llllll}0.0 & 0.0 & 0.0 & 0.0 & 0.0 & 146,365\end{array}$

$\begin{array}{llllll}0.1 & 0.2 & 0.0 & 0.0 & 0.0 & 150,365\end{array}$

$\begin{array}{llllll}3.4 & 1.0 & 1.6 & 0.8 & 0.1 & 213,449\end{array}$

$\begin{array}{llllll}7.8 & 0.0 & 0.0 & 0.0 & 0.0 & 144,120\end{array}$

$\begin{array}{llllll}0.0 & 0.1 & 0.0 & 0.0 & 0.0 & 93,664\end{array}$

$\begin{array}{llllll}45.9 & 16.4 & 0.0 & 0.0 & 0.0 & 144,950\end{array}$

$\begin{array}{llllll}53.8 & 23.4 & 0.0 & 0.0 & 0.0 & 211,814\end{array}$

$\begin{array}{llllll}0.1 & 0.0 & 0.0 & 0.0 & 0.0 & 102,743\end{array}$

$\begin{array}{llllll}0.0 & 0.0 & 0.0 & 0.0 & 0.0 & 115,310\end{array}$

$\begin{array}{llllll}13.3 & 1.5 & 0.6 & 0.2 & 0.0 & 80,277\end{array}$

$\begin{array}{llllll}3.5 & 0.5 & 0.1 & 0.0 & 0.0 & 25,477\end{array}$

$\begin{array}{llllll}23.4 & 1.7 & 3.1 & 1.3 & 0.0 & 20,265\end{array}$

$\begin{array}{llllll}9.4 & 0.9 & 0.4 & 0.0 & 0.0 & 147,511\end{array}$

$\begin{array}{llllll}17.0 & 31.0 & 0.0 & 0.0 & 0.0 & 266,030\end{array}$

$\begin{array}{llllll}0.0 & 0.0 & 0.0 & 0.0 & 0.0 & 122,333\end{array}$

$\begin{array}{llllll}6.0 & 0.0 & 0.0 & 0.0 & 0.0 & 178,568\end{array}$

$\begin{array}{llllll}19.9 & 12.4 & 3.0 & 1.2 & 0 & 0\end{array}$

$\begin{array}{lllllll}51.3 & 14.9 & 0.0 & 0.0 & 0.8 & 198,508\end{array}$

$\begin{array}{llllll}0.7 & 0.8 & 0.7 & 0.5 & 0.1 & 284,624\end{array}$

$\begin{array}{llllll}1.5 & 1.5 & 1.3 & 0.4 & 0.8 & 23,292\end{array}$

$\begin{array}{llllll}12.7 & 1.2 & 0.0 & 0.6 & 0.0 & 19,342\end{array}$

$\begin{array}{llllll}18.1 & 1.8 & 0.2 & 0.4 & 0.0 & 314,258\end{array}$

$\begin{array}{llllll}19.8 & 1.8 & 0.1 & 0.0 & 0.0 & 122,707\end{array}$

$\begin{array}{lllllll}0.9 & 0.2 & 0.4 & 0.1 & 0.0 & 126,504\end{array}$

$\begin{array}{llllll}0.5 & 65.7 & 12.3 & 0.0 & 0.0 & 183,113\end{array}$

$\begin{array}{llllll}0.8 & 0.3 & 0.6 & 0.0 & 0.0 & 106,210\end{array}$

$\begin{array}{llllll}43.4 & 28.2 & 0.0 & 0.0 & 0 . \emptyset & 177,817\end{array}$

$\begin{array}{llllll}0.4 & 3.2 & 0.4 & 0.0 & 0.0 & 249,117\end{array}$

$\begin{array}{llllll}6.0 & 2.9 & 0.1 & 0.0 & 0.0 & 116,260\end{array}$

$\begin{array}{llllll}7.5 & 1.2 & 0.0 & 0.0 & 0.0 & 2,732\end{array}$

$\begin{array}{llllll}0.1 & 0.1 & 0.0 & 0.0 & 0.0 & 78,227\end{array}$

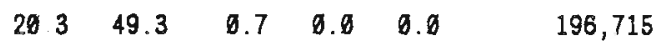

$\begin{array}{llllll}0.2 & 0.2 & 0.1 & 0.0 & 0.0 & 106,591\end{array}$

$\begin{array}{llllll}22.3 & 5.8 & 0.1 & 0.0 & 0.0 & 678,623\end{array}$

$\begin{array}{llllll}0.8 & 0.3 & 0.3 & 1.0 & 0.1 & 212,569\end{array}$

$\begin{array}{llllll}1.0 & 1.8 & 1.7 & 0.2 & 0.0 & 24,017\end{array}$

$\begin{array}{llllll}2.7 & 0.6 & 0.1 & 0.8 & 0.0 & 102,832\end{array}$

$\begin{array}{llllll}0.9 & 1.8 & 1.6 & 0.2 & 0.0 & 172,264\end{array}$

$\begin{array}{llllll}1.4 & 0.8 & 0.4 & 0.0 & 0.0 & 62,468\end{array}$

$\begin{array}{llllll}7.9 & 0.6 & 0.1 & 0.0 & 0.5 & 140,964\end{array}$

$\begin{array}{llllll}14.3 & 13.5 & 0.3 & 7.2 & 0.1 & 251,201\end{array}$

$\begin{array}{llllll}11.8 & 8.8 & 0.7 & 0.5 & 0.0 & 7,675,265\end{array}$ 
TABLE 6. State Land Area by Power Class for Land Exclusion Scenario 2 (Environmental Exclusions)

Total

State

Alabama

Arizona

Arkansas

California

Colorado

Connecticut

Delaware

Florida

Georgia

Idaho

Illinois

Indiana

Iowa

Kanisas

Kentucky

Louisiana

Haine

Haryland

Nassachusetts

Michigan

Minnesota

Mississippi

Missouri

Montana

Nebraska

Nevada

New Hampshire

New Jersey

New Mexico

New York

North Carolina

North Dakota

Ohio

Ok lahona

Dregon

Pennsylvania

Rhode Island

South Carolina

South Dakota

Tennessee

Texas

Utah

Vermont

Virginia

Mashington

West Virginia

iisconsin

Hyon ing

Total
Square Kil ometers per Power Class

\begin{tabular}{llllll}
\multicolumn{4}{c}{ Square } & Kil ometers & per Power Class \\
\hline 3 & 4 & 5 & 6 & 7
\end{tabular}

$\frac{\text { Percentage of Land per Power Class }}{3}$

Land, $\mathrm{km} 2$

$\begin{array}{rrrrr}0 & 0 & 0 & 0 & \\ 867 & 186 & 364 & 28 & \\ 3,819 & 369 & 34 & 0 & \\ 3,866 & 1,598 & 489 & 1,073 & 31 \\ 25,589 & 31,219 & 51 & 561 & 61 \\ 974 & 64 & 5 & 0 & \\ 295 & 14 & 0 & 0 & \\ 0 & 0 & 0 & 0 & 0 \\ 118 & 141 & 11 & 0 & \\ 6,532 & 115 & 950 & 304 & 22\end{array}$

$0.00 .00 .00 .0 \quad 0.0 \quad 131,487$

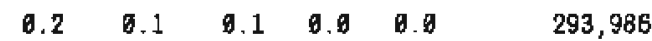

$\begin{array}{llllll}2.8 & 0.3 & 0.0 & 0.0 & 134,983\end{array}$

$1.00 .40 .19 .3 \quad 0.0 \quad 494,815$

$\begin{array}{llllll}9.5 & 11.8 & 0.0 & 0.2 & 0.0 & 268,311\end{array}$

$\begin{array}{llllll}6.9 & 0.5 & 0.0 & 0.0 & 0.0 & 12,518\end{array}$

$\begin{array}{llllll}5.9 & 0.3 & 0.0 & 0.0 & 0.0 & 5,005\end{array}$

$\begin{array}{llllll}0.0 & 0.6 & 0.0 & 0.0 & 0.0 & 146,365\end{array}$

$\begin{array}{llllll}0.1 & 0.1 & 0.9 & 0.9 & 0.9 & 156,365\end{array}$

$\begin{array}{llllll}3.1 & 0.4 & 9.4 & 9.1 & 0.0 & 213,449\end{array}$

$\begin{array}{llllll}6.9 & 0.6 & 0.9 & 0.9 & 0.9 & 144,126\end{array}$

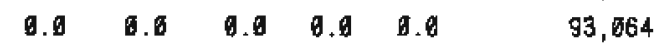

$\begin{array}{llllll}41.3 & 14.8 & 0.9 & 0.0 & 0.9 & 144,950\end{array}$

$48.421 .6 \quad$ 9.9 $9.9 \quad 0.9 \quad 211,814$

$\begin{array}{llllll}0.1 & 0.0 & 0.0 & 0.02,743\end{array}$

$0.00 .00 .0 .0 .0 .015,310$

$\begin{array}{llllll}11.6 & 0.7 & 0.3 & 0.1 & \text { g. } & 90,277\end{array}$

$\begin{array}{llllll}1.6 & 0.3 & 0.0 & 0.8 & 0.8 & 25,477\end{array}$

$\begin{array}{llllll}17.8 & 0.9 & 1.4 & 0.8 & 0.0 & 29,255\end{array}$

$\begin{array}{llllll}8.2 & 0.4 & 0.2 & 0.0 & 6.8 & 147,511\end{array}$

$\begin{array}{llllll}15.1 & 27.9 & 0.6 & 0.6 & 0.0 & 296,830\end{array}$

$\begin{array}{llllll}0.6 & 0.0 & 6.6 & 6.6 & 0.0 & 122,333\end{array}$

$\begin{array}{llllll}5.2 & 0.0 & 0.0 & 0.0 & 0.0 & 178,568\end{array}$

$\begin{array}{llllll}17.6 & 16.8 & 2.0 & 0.7 & 0.0 & 376,564\end{array}$

$\begin{array}{llllll}48.1 & 13.4 & 0.9 & 0.0 & 198,568\end{array}$

$\begin{array}{llllll}0.4 & 0.5 & 0.4 & 0.3 & 0.5 & 284,624\end{array}$

$\begin{array}{llllll}1.2 & 0.9 & 0.8 & 0.2 & 0.6 & 23,292\end{array}$

$\begin{array}{llllll}8.5 & 0.6 & 6.6 & 0.6 & 0.6 & 19,342\end{array}$

$\begin{array}{llllll}18.2 & 1.8 & 0.1 & 0.1 & 0.9 & 314,258\end{array}$

$\begin{array}{llllll}7.4 & 1.1 & 0.1 & 0.9 & 9.9 & 122,707\end{array}$

$\begin{array}{llllll}0.4 & 0.1 & 0.2 & 0.1 & 0.6 & 128,504\end{array}$

$0.458 .9 \quad 11.1 \quad 0.8 \quad 0.6 \quad 183,113$

$\begin{array}{llllll}0.4 & 0.1 & 0.0 & 0.0 & 0.9 & 166,210\end{array}$

$38.9 \quad 18.1 \quad 0.0 \quad 0.00 .0 \quad 177,917$

$\begin{array}{llllll}0.3 & 1.7 & 0.2 & 0.0 & 0.0 & 249,117\end{array}$

$\begin{array}{llllll}4.6 & 2.1 & 0.0 & 0.0 & 116,260\end{array}$

$\begin{array}{llllll}3.6 & 0.5 & 0.0 & 0.6 & 0.0 & 2,732\end{array}$

$\begin{array}{lllllll}0.1 & 0.6 & 0.0 & 0.0 & 0.0 & 78,227\end{array}$

$\begin{array}{llllll}18.2 & 44.3 & 0.6 & 0.6 & 0.0 & 196,715\end{array}$

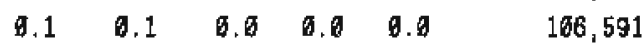

$19.4 \quad 5.2 \quad 0.1 \quad 0.6 \quad 0.6 \quad 678,623$

$\begin{array}{llllll}0.6 & 0.2 & 0.1 & 0.4 & 0.0 & 212,589\end{array}$

$\begin{array}{llllll}9.8 & 1.1 & 1.0 & 0.1 & 0.0 & 24,017\end{array}$

$\begin{array}{llllll}1.5 & 0.3 & 0.1 & 6.6 & 0.0 & 162,832\end{array}$

$\begin{array}{lllllll}9.5 & 0.9 & 0.8 & 0.1 & 0.0 & 172,254\end{array}$

$\begin{array}{llllll}0.8 & 0.5 & 0.2 & 0.0 & 0.9 & 52,458\end{array}$

$\begin{array}{llllll}0.1 & 0.3 & 0.0 & 0.0 & 0.0 & 140.964\end{array}$

$\begin{array}{llllll}12.6 & 11.8 & 0.1 & 5.5 & 0.0 & 251,201\end{array}$

$\begin{array}{lllllll}10.3 & 7.6 & 0.5 & 0.3 & 6.8 & 7,575,285\end{array}$ 
TABLE 7. State Land Area by Power Class for Land Exclusion Scenario 3 (Environmental and Moderate Land-Use Exclusions)

Total

\begin{tabular}{|c|c|c|c|c|c|}
\hline \multirow[t]{2}{*}{ State } & \multicolumn{5}{|c|}{ Square Ki lometers per Power Class } \\
\hline & 3 & 4 & 5 & 6 & 7 \\
\hline Alabama & $\emptyset$ & $\theta$ & $\emptyset$ & 8 & $b$ \\
\hline Arizona & 499 & 142 & 211 & 19 & $\emptyset$ \\
\hline Arkansas & 2,189 & 195 & 18 & $\theta$ & $\theta$ \\
\hline California & 2,992 & 1,168 & $3 g_{1}$ & 768 & 23 \\
\hline Colorado & 20,330 & 24,899 & 29 & 352 & 38 \\
\hline Connecticut & 507 & 33 & 2 & 6 & $\theta$ \\
\hline Delaware & 179 & 8 & 0 & $\theta$ & $\theta$ \\
\hline Florida & $\emptyset$ & $\emptyset$ & 8 & $\theta$ & $\theta$ \\
\hline Georgia & 61 & 73 & 5 & 6 & $\theta$ \\
\hline Idaho & 5,741 & 613 & 648 & 224 & 17 \\
\hline Illinois & 6,786 & 8 & 0 & $\theta$ & $\theta$ \\
\hline Indiana & $g$ & 22 & $\theta$ & 6 & $\theta$ \\
\hline Iowa & 41,695 & 15,607 & $\theta$ & 6 & $\theta$ \\
\hline Kansas & 75,388 & 33,264 & $\emptyset$ & ø & 0 \\
\hline Kentucky & 29 & 3 & 0 & 6 & 0 \\
\hline Louisiana & 0 & 6 & 0 & 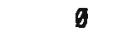 & 0 \\
\hline Maine & 5,287 & 435 & 148 & 57 & 4 \\
\hline Maryland & 268 & 41 & 3 & $\theta$ & $\theta$ \\
\hline Massachusetts & 2,869 & 121 & 246 & 119 & $\theta$ \\
\hline Michigan & 6,141 & 558 & 240 & $\emptyset$ & $\theta$ \\
\hline Minnesota & 20,875 & 40,214 & 0 & $\theta$ & $\theta$ \\
\hline Mississippi & 8 & $\emptyset$ & 0 & $g$ & 6 \\
\hline Missouri & 5,788 & $\theta$ & $\theta$ & $\theta$ & 6 \\
\hline Montana & 55,797 & 33,528 & 5,864 & 2,116 & 24 \\
\hline Nebraska & 69,693 & 21,051 & 0 & $\theta$ & $\theta$ \\
\hline Nevada & 1,110 & 1,152 & 925 & 675 & 65 \\
\hline New Hampshire & 141 & 109 & 95 & 25 & 1 \\
\hline New Jersey & 1,044 & 90 & $\emptyset$ & $g$ & $\sigma$ \\
\hline New Mexico & 42,148 & 3,989 & 150 & 383 & 29 \\
\hline New York & 5,599 & 918 & 51 & 4 & ø \\
\hline North Carolina & 444 & 68 & 128 & 35 & 2 \\
\hline North Dakota & 569 & 84,255 & 15,893 & 6 & $\theta$ \\
\hline Ohio & 255 & 110 & $\theta$ & 6 & $\theta$ \\
\hline Ok | ahoma & 47,371 & 25,517 & 3 & 6 & 8 \\
\hline Oregon & 559 & 2,850 & 285 & 17 & $\theta$ \\
\hline Pennsy / vania & 3,158 & 1,372 & 28 & $\emptyset$ & 8 \\
\hline Rhode Is land & 86 & 14 & 0 & $\theta$ & $\theta$ \\
\hline South Carolina & 41 & 10 & 1 & $\emptyset$ & $\theta$ \\
\hline South Dakota & 25,626 & 67,257 & 841 & 0 & $\emptyset$ \\
\hline Tennessee & 63 & 56 & 17 & 7 & 6 \\
\hline Texas & 94,918 & 28,396 & 285 & 82 & 6 \\
\hline Utah & 1,800 & 241 & 154 & 532 & 28 \\
\hline Vermont & 111 & 142 & 128 & 12 & $\theta$ \\
\hline Virginia & 1,051 & 184 & 30 & 1 & $\theta$ \\
\hline Washington & 593 & 1,148 & 913 & 55 & 2 \\
\hline West Virginia & 255 & 156 & 68 & 5 & $\theta$ \\
\hline Wisconsin & 5,762 & 312 & 56 & 0 & $\theta$ \\
\hline Wyoming & 26,603 & 25,390 & 178 & 11,801 & 34 \\
\hline Total & 579,449 & 415,117 & 27,944 & 17,263 & 273 \\
\hline
\end{tabular}

Percentage of Land per Power Class

Land, $\mathrm{km}^{2}$

$\begin{array}{llllll}0.0 & 0.0 & 0.0 & 0.0 & 0.0 & 131,487\end{array}$

$\begin{array}{lllllll}0.2 & 0.1 & 0.1 & 0.0 & 0.0 & 293,986\end{array}$

$\begin{array}{llllll}1.6 & 0.1 & 0.0 & 0.0 & 0.0 & 134,883\end{array}$

$\begin{array}{llllll}0.7 & 0.3 & 0.1 & 0.2 & 0.6 & 494,815\end{array}$

$\begin{array}{llllll}7.8 & 9.3 & 0.0 & 6.1 & 0.6 & 268,311\end{array}$

$\begin{array}{llllll}4.6 & 0.3 & 0.0 & 0.0 & 0.0 & 12,618\end{array}$

$\begin{array}{llllll}3.6 & 0.2 & 0.0 & 0.0 & 0.0 & 5,065\end{array}$

$0.0 \quad 0.0 \quad 0.0 \quad 0.0 \quad 0.0 \quad 146,365$

$\begin{array}{llllll}0.0 & 0.1 & 0.0 & 0.0 & 0.6 & 150,365\end{array}$

$\begin{array}{llllll}2.7 & 0.3 & 0.3 & 0.1 & 0.0 & 213,449\end{array}$

$4.7 \quad 0.6 \quad 0.0 \quad 0.0 \quad 0.0 \quad 144,120$

$\begin{array}{llllll}0.0 & 0.0 & 0.0 & 0.0 & 0.0 & 93,064\end{array}$

$\begin{array}{llllll}28.8 & 10.4 & 0.6 & 0.6 & 0.0 & 144,950\end{array}$

$\begin{array}{llllll}35.6 & 15.7 & 0.0 & 0.0 & 0.0 & 211,814\end{array}$

$\begin{array}{llllll}0.0 & 0.0 & 0.0 & 0.0 & 0.0 & 102,743\end{array}$

$\begin{array}{llllll}0.0 & 0.0 & 0.6 & 0.0 & 0.0 & 115,310\end{array}$

$\begin{array}{lllllll}6.6 & 0.5 & 0.2 & 0.1 & 0.0 & 80,277\end{array}$

$\begin{array}{llllll}1.0 & 0.2 & 0.0 & 0.0 & 0.0 & 25,477\end{array}$

$\begin{array}{llllll}9.9 & 0.6 & 1.2 & 0.6 & 0.0 & 20,265\end{array}$

$\begin{array}{llllll}4.2 & 0.4 & 0.2 & 0.0 & 0.6 & 147,511\end{array}$

$\begin{array}{llllll}10.1 & 19.5 & 0.0 & 0.0 & 0.0 & 206,030\end{array}$

$\begin{array}{llllll}0.0 & 0.0 & 0.0 & 0.0 & 0.0 & 122,333\end{array}$

$\begin{array}{llllll}3.2 & 0.0 & 0.0 & 0.0 & 0.0 & 178,568\end{array}$

$\begin{array}{llllll}14.8 & 8.9 & 1.6 & 0.6 & 0.0 & 376,564\end{array}$

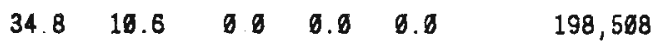

$\begin{array}{lllllll}0.4 & 0.4 & 0.3 & 0.2 & 0.0 & 284,624\end{array}$

$\begin{array}{llllll}0.6 & 0.5 & 0.4 & 0.1 & 0.0 & 23,292\end{array}$

$\begin{array}{lllllll}5.4 & 0.5 & 0.0 & 0.0 & 0.0 & 19,342\end{array}$

$\begin{array}{llllll}13.4 & 1.3 & 0.1 & 0.1 & 0.0 & 314,258\end{array}$

$\begin{array}{llllll}4.6 & 0.8 & 0.0 & 0.0 & 0.0 & 122,707\end{array}$

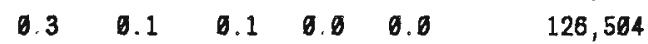

$\begin{array}{llllll}0.3 & 46.0 & 8.7 & 0.0 & 0.0 & 183,113\end{array}$

$\begin{array}{lllllll}0.2 & 0.1 & 0.0 & 0.0 & 0.0 & 196,210\end{array}$

$\begin{array}{llllll}26.6 & 14.4 & 0.8 & 0.0 & 0.0 & 177,817\end{array}$

$\begin{array}{llllll}0.2 & 1.1 & 0.1 & 0.8 & 0.0 & 249,117\end{array}$

$\begin{array}{lllllll}2.7 & 1.2 & 0.6 & 0.8 & 0.0 & 118,260\end{array}$

$\begin{array}{llllll}3.2 & 0.5 & 0.0 & 0.0 & 0.0 & 2,732\end{array}$

$\begin{array}{lllllll}0.1 & 0.0 & 0.0 & 0.0 & 0.0 & 78,227\end{array}$

$\begin{array}{llllll}13.0 & 34.2 & 0.4 & 0.0 & 0.0 & 196,715\end{array}$

$\begin{array}{llllll}0.1 & 0.1 & 0.0 & 0.0 & 0.0 & 166,591\end{array}$

$14.04 .2 \quad 0.0 \quad 0.0 .078,623$

$\begin{array}{llllll}0.5 & 0.1 & 0.1 & 0.2 & 0.0 & 212,569\end{array}$

$\begin{array}{llllll}0.5 & 0.6 & 0.5 & 0.1 & 0.0 & 24,017\end{array}$

$\begin{array}{llllll}1.0 & 0.2 & 0.0 & 0.0 & 0.0 & 102,832\end{array}$

$\begin{array}{llllll}0.3 & 0.7 & 0.5 & 0.0 & 0.0 & 172,264\end{array}$

$\begin{array}{llllll}0.4 & 0.2 & 0.1 & 0.0 & 0.0 & 62,468\end{array}$

$\begin{array}{llllll}4.1 & 0.2 & 0.0 & 0.0 & 0.0 & 140,964\end{array}$

$\begin{array}{llllll}10.4 & 10.1 & 0.1 & 4.7 & 0.0 & 251,201\end{array}$

$\begin{array}{llllll}7.5 & 5.4 & 0.4 & 0.2 & 0 . \emptyset & 7,675,265\end{array}$ 
TABLE 8. State Land Area by Power Class for Land Exclusion Scenario 4 (Environmental and Severe Land-lJse Exclusions)

Tota I

State

Alabana

Arkansas

California

Colorado

Connecticut

Delaware

Florida

Georgia

Idaho

Illinois

Indiana

Iowa

Kansas

Kentucky

Louis iana

Waine

Maryl and

Massachusetts

Michigan

Minnesota

Mississippi

Missouri

Montana

Nebraska

Nevada

New Hanpshire

New Jersey

Now Hexico

New York

North Carolina

North Dakota

ohio

oklahona

Oregon

Pennsy I van ia

Rhode Island

South Carolina

South Cakota

Tennessee

Texas

Utak

Vermont

Virginia

Wash i ngton

West Virginia

iscons in

Hyoming

Total
Square Kiloneters por Power Class

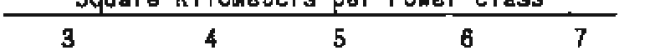$$
511
$$

367

12

2,258

11,397

197

45

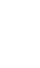

$$
5,486
$$

261

5

16,702

.

0
1,676

91

599

2,978

784

6

45,12

23,036

1,050

20

329

31,899

1,329

$3 \mathrm{Bg}$

321

129

8,365

439

244

77

2,618

37, 520

738

20

465

243

901

19,930

216,644

\begin{tabular}{|c|c|c|c|}
\hline 8 & 9 & $\theta$ & 5 \\
\hline $10 \mathrm{~B}$ & 139 & 11 & $\theta$ \\
\hline$\theta$ & 6 & 0 & 0 \\
\hline 728 & 217 & 489 & 15 \\
\hline 13,962 & 7 & 148 & 16 \\
\hline 4 & $\theta$ & $\theta$ & G \\
\hline 1 & 0 & 6 & $\theta$ \\
\hline 6 & $\theta$ & 0 & $\sigma$ \\
\hline 1 & 6 & 6 & $\theta$ \\
\hline 417 & 324 & 152 & 13 \\
\hline 6 & 0 & $\theta$ & $\theta$ \\
\hline 14 & 8 & 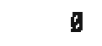 & B \\
\hline 12 & 6 & 6 & 9 \\
\hline 9,119 & $\theta$ & 6 & 9 \\
\hline 0 & 6 & 0 & $\theta$ \\
\hline 0 & $\emptyset$ & $\theta$ & $g$ \\
\hline 314 & 18 & 9 & b \\
\hline 4 & $\sigma$ & 9 & 0 \\
\hline 65 & 268 & 119 & g \\
\hline 459 & 219 & 6 & a \\
\hline 730 & $\theta$ & 9 & 9 \\
\hline 6 & 6 & 0 & $g$ \\
\hline 0 & 6 & 9 & 9 \\
\hline 25,787 & 4,925 & 1,581 & 17 \\
\hline 11,424 & 0 & 0 & ด \\
\hline 1,016 & 915 & 587 & 56 \\
\hline 12 & 10 & 1 & $\theta$ \\
\hline 77 & 0 & 0 & $\theta$ \\
\hline 2,207 & 87 & 197 & 18 \\
\hline 402 & 5 & 6 & $\theta$ \\
\hline 3 & 4 & 6 & 9 \\
\hline 39,513 & 8,607 & 9 & 9 \\
\hline 98 & 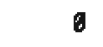 & 0 & $g$ \\
\hline 13,736 & a & 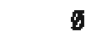 & $\theta$ \\
\hline 1,371 & 143 & 7 & 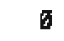 \\
\hline 81 & $\theta$ & $\theta$ & 8 \\
\hline 14 & 9 & $\theta$ & 6 \\
\hline 6 & 6 & 9 & 0 \\
\hline 27,821 & 2 & 9 & $\theta$ \\
\hline 2 & 6 & 8 & 6 \\
\hline 15,931 & 272 & 81 & 只 \\
\hline 169 & 95 & 293 & 14 \\
\hline 17 & 14 & 1 & E \\
\hline 14 & 8 & 6 & $\theta$ \\
\hline B78 & 504 & 21 & t) \\
\hline 4 & 1 & 6 & 6 \\
\hline 287 & 56 & 6 & $b$ \\
\hline 22,193 & 142 & 10,835 & 24 \\
\hline 132 & 365 & 14,532 & 179 \\
\hline
\end{tabular}

Land, $\mathrm{km}^{2}$

$\frac{\text { Percentage of Land per Power Class }}{3}$

$\begin{array}{llllll}0.1 & 0.0 & 0.0 & 0.0 & 0.0\end{array}$

293,986

$0.0 \quad 0.0 \quad 0.6 \quad 0.60 .0$

$9.6 \quad 0.2 \quad 0.1 \quad 0.1 \quad 0.0$

134,883

494,815

$\begin{array}{lllll}4.2 & 5.2 & 0.0 & 0.1 & 0.0\end{array}$

$\begin{array}{lllll}0.9 & 0.0 & 0.9 & 0.0 & 0.0\end{array}$

268,311

$0.90 .0 \quad 0.0 \quad 0.0 \quad 0.0$

12,818

$\begin{array}{llllll}0.9 & 0.0 & 0.6 & 0.9 & 0.0\end{array}$

5,605

$0.0 \quad 0.0 \quad 0.0 \quad 0.0 \quad 0.6$

149,365

$\begin{array}{lllll}2.6 & 0.2 & 0.2 & 0.1 & 0.0\end{array}$

150,365

0.20 .00 .00 .000

213,449

$0.00 .90 .6 \quad 0.00 .0$

144,120

0.10 .00 .00000

93,984

$\begin{array}{lllll}7.9 & 4.3 & 0.0 & 0.6 & 0.6\end{array}$

144,956

0.00 .60 .60 .60 .0

211,814

102,743

115,318

Bg, 277

$\begin{array}{lllll}1.3 & 0.4 & 0.6 & 0.6 & 0.0\end{array}$

25,477

29,265

$\begin{array}{lllll}2.9 & 0.3 & 1.0 & 0.6 & 0.6\end{array}$

147,511

$\begin{array}{lllll}1.4 & 0.3 & 0.2 & 0.6 & 6.6\end{array}$

$0.40 .3 \quad 0.6 \quad 0.6 \quad 0.6$

206,030

$0.00 .0 \quad 0.0 \quad 0.0 \quad 0.0$

122,393

$0.6 \quad 0.0 \quad 0.0 \quad 0.6 \quad 6.0$

$178,56 \mathrm{~B}$

$\begin{array}{lllll}12 . & 6.7 & 1.1 & 0.4 & 0.6\end{array}$

376,564

$\begin{array}{lllll}11.6 & 5.8 & 8.6 & 0.0 & 0.6\end{array}$

$\begin{array}{llllll}0.4 & 0.4 & 0.3 & 0.2 & 0.0\end{array}$

198,508

0.10 .10 .00 .60 .6

284,624

$\begin{array}{lllll}1.7 & 0.4 & 0.6 & 0.0 & 6.0\end{array}$

23,292

$16.10 .7 \quad 0.0 \quad 0.1 \quad 0.0$

19,342

314,256

122,797

126,584

$\begin{array}{llllll}0.3 & 0.0 & 0.0 & 0.0 & 0.0\end{array}$

183,113

$\begin{array}{lllll}0.2 & 21.6 & 4.4 & 0.0 & 0.0\end{array}$

108,210

$\begin{array}{lllll}0.1 & 0.1 & 0.0 & 0.0 & 0.0\end{array}$

177,817

$4.7 \quad 7.7$

$9.0 \quad 6.0 \quad 0.6$

249,117

116,260

$0.2 \quad 0.1 \quad 0.0 \quad 0.0 \quad 0.0$

2,732

$0.80 .0 \quad 0.0 \quad 0.0 \quad 0.0$

78,227

$1.3 \quad 14.1$

0.80 .00 .0

196,715

106,591

$\begin{array}{lllll}5.5 & 2.3 & 9.6 & 0.6 & 0.0\end{array}$

678,623

$\begin{array}{lllll}0.3 & 0.1 & 0.0 & 0.1 & 0.6\end{array}$

212,589

$\begin{array}{lllll}0.1 & 0.1 & 0.1 & 0.0 & 0.0\end{array}$

24,017

$\begin{array}{lllll}0.4 & 0.9 & 0.0 & 0.0 & 0.0\end{array}$

102,832

$\begin{array}{lllll}0.1 & 0.4 & 0.3 & 0.0 & 0.0\end{array}$

172,264

$0.00 .0 \quad 0.0 \quad 0.8 \quad 0.0$

62,468

$\begin{array}{lllll}0.7 & 0.2 & 0.0 & 0.6 & 0.0\end{array}$

146,964

$\begin{array}{lllll}7.9 & 8.8 & 0.1 & 4.3 & 0.8\end{array}$

251,261

$2.8 \quad 2.4$

$0.2 \quad 0.2 \quad 0.0$

$7,675,265$ 


\subsection{SCENARIO 1 - NO EXCLUSIONS}

Scenario 1 represents the base case, drawn from areal estimates produced in the resource assessment analyses, with no environmental or land-use exclusions. For the no-exclusion scenario, the area for class 5 and above (i.e., the power class levels of the California passes that are currently supporting successful wind plants) is equivalent to an area approximately the size of Virginia. Similarly, the area for power classes 4 and greater is equivalent to an area approximately the size of Texas, and that for power class 3 and greater is equivalent to one four times the size of California.

The estimate of land area with class 3 and higher wind resource represents the summation of the grid cell land areas shown in Figure 2. In that figure, the percentage of a grid cell's land area with class 3 and higher resource is a function of the land-surface form and is shown by the four categories of percentage of land area: $1-20 \%, 21-50 \%, 51-80 \%$, and $81-100 \%$.

The $1-20 \%$ category is largely mountainous terrain, where only a smal1 fraction of the land area in a grid cell (e.g., the ridge crests and mountain summits) is windy. Although the actual area of windy land in mountainous areas may vary considerably, depending on the spatial distribution of the mountains and ridges, we have determined that, on the average, roughly $5 \%$ of 1 and area is wel1-exposed terrain features such as ridge crests and mountain summits, whereas $95 \%$ of the land area is sheltered terrain such as valleys and hillsides. To account for local areas of acceleration in mountainous terrain, in which the wind resource may be higher than the average (assigned) wind power class for ridge crests, we assume that $10 \%$ of the land area represented by ridge crests (i.e., $10 \%$ of $5 \%$, or $0.5 \%$ of the grid cell's total area) is one wind power class higher than the assigned value. For example, although the U.S. annual average wind power map in Figure 1 does not have any grid cells with class 7 average (assigned) wind power, data included in the U.S. atlas (Elliott et al. 1987) show that class 7 sites exist where the terrain causes a local acceleration of the winds. Therefore, in mountainous terrain represented by the $1-20 \%$ category in Figure 2, we assume that $4.5 \%$ (i.e., 0.9 times $5 \%$ ) of the grid cell's land area is represented by the assigned wind power class and that $0.5 \%$ (i.e., 0.1 times $5 \%$ ) of the 1 and area 
is one power class higher than the assigned power class. As a result of this assumption, we have estimated that there is about $1,500 \mathrm{~km}^{2}$ of land area with class 7 wind resource in the contiguous United States before environmental and 1 and-use restrictions are applied (see Table 4). To put this area of $1,500 \mathrm{~km}^{2}$ into perspective, one grid cell (at say $40^{\circ} \mathrm{N}$ ) is approximately $800 \mathrm{~km}^{2}$, so all of the class 7 land area combined is still slightly smaller than the area of two grid cells in Figure 1.

For the other three categories of percentage of land area shown in Figure 2 (i.e., 21-50\%, 51-80\%, and 81-100\%), we have used the approximate midpoint of each interval $(35 \%, 65 \%$, and $90 \%)$ in computing the areal estimates shown in Figure 6 and Table 4. Considering the large uncertainties in the subjective assignment of percentage of land area that is exposed for the various land-surface forms, we did not feel that any greater precision in our specification of the values of percentage of land area with a given wind power class was justified. For each grid cel1, the land area that is represented by the assigned power class in Figure 1 is computed by multiplying the grid cell's total land area by the percentage of land area of the grid cell in Figure 2 (using the percentages given above for the four categories). In our areal estimates, we have not accounted for any of the remaining land area that is less than the assigned power class in Figure 1 (i.e., all of the remaining land area is excluded and could be considered to have class 1 or 2 wind resource). For example, in much of the Sand Hills of Nebraska and Flint Hi11s of Kansas, where $35 \%$ of the land area was estimated to have wind power class 4 , the remaining $65 \%$ of the 1 and area in each grid cell was excluded or considered to have low wind resource. However, some of the land area in those grid cells assigned power class 4 may actualiy have class 3 or possibiy class 5 resource, or even lower wind resources (class 1 or 2). In flatter areas such as southwestern Kansas, where 90\% of the land area was estimated to have wind power class 4 , the remaining $10 \%$ of the land area was excluded. In reality, the wind resource could be distributed over more power classes (for example, although most of the 1 and area is estimated to be class 4 , there may be some class 3 and possibly class 5 areas, as well as some low resource areas). Local variability of the wind resource in a region of relatively flat terrain in the Great Plains has been described by Kessler and Eyster (1987). 


\subsection{SCENARIO 2 - ENVIRONMENTAL EXCLUSIONS}

Scenario 2, in which we exclude all of the environmental 1 and area (as approximated in Figure 4), shows a 35\% decrease from the base case in the area having class 5 and greater but only a 14\% decrease in the area having class 3 and greater. In general, the estimates of land excluded by environmental considerations probably exceed the exclusions that would be calculated if actual (rather than approximated) areas were used.

Areas of class 7 are most affected by the environmental exclusions: $75 \%$ of the class 7 area is eliminated when environmental restrictions are applied, because most of the class 7 areas are ridge crest sites in the high mountains of the West, where environmental exclusions are greatest. For example, in Colorado (the state with the largest amount of class 7 land area before environmental exclusions), the class 7 land area decreases from $376 \mathrm{~km}^{2}$ in the base case to $61 \mathrm{~km}^{2}$ after environmental exclusions. All of Colorado's class 7 lands are high ridge crests in the Rocky Mountains, where most of the land is excluded by environmental considerations. On the other hand, Nevada (which ranked fifth in class 7 land area in the base case, with $137 \mathrm{~km}^{2}$ ) ranked first in class 7 land area after environmental exclusions, with an estimated $79 \mathrm{~km}^{2}$. Although all of Nevada's class 7 lands are also ridge crests, the mountains of the Great Basin Plateau in Nevada (where roughly $40 \%$ of the land area was excluded based on environmental considerations) have fewer designated natural areas and are generaliy more accessible than the more rugged Rocky Mountains in Colorado.

The percent reduction in class 6 land area from environmental exclusions is $40 \%$ for the contiguous United States. Wyoming (which has considerably more class 6 area than any other state) has $65 \%$ of the class 6 area in the contiguous United States after environmental exclusions, compared to $51 \%$ of the class 6 area before environmental exclusions. In wyoming, where much of the class 6 area is in the high plains of the south, the percent reduction in class 6 area from environmental exclusions is only 24\%. The class 6 plains of southern wyoming represent the largest class 6 area in the contiguous United States. Most of the remaining class 6 lands in the contiguous United States are high ridge crests in mountainous terrain where accessibility and siting may be difficult. If we exclude wyoming, the percent reduction in class 6 
for the rest of the contiguous United States from environmental exclusions is $68 \%$. Although most of the class 6 lands (excluding those in Wyoming) are high ridge crests in mountainous terrain, there are some notable areas that are not high ridge crests. For example, a significant fraction of the class 6 lands in California and Montana are relatively low-elevation wind corridors (e.g., passes or valleys) more conducive to wind turbine siting than high ridge crests in mountainous terrain. In Massachusetts, the eastern state with the largest class 6 area after environmental exclusions (with $119 \mathrm{~km}^{2}$ ), the class 6 lands are exposed coastal areas and islands, where $50 \%$ of the 1 and area was exciuded by environmental restrictions.

The percent reduction in class 5 land area from environmental exclusions is $31 \%$ for the contiguous United States. Most of the class 51 and area is located in North Dakota and Montana, which together account for $76 \%$ of the class 5 area in the contiguous United States after environmental exclusions. The percent reductions in class 5 land area from environmental exclusions in North Dakota and Montana are $10 \%$ and $32 \%$, respectively.

The percent reduction in 1 and area for classes 3 and 4 is $13 \%$ each for the contiguous United States. Most of the class 3 and 4 areas are located in flatter regions, where only $10 \%$ of the land was excluded by environmental restrictions. Class 3 and 4 lands account for about $10.3 \%$ and $7.0 \%$, respectively, of the total U.S. land area. North Dakota and South Dakota, the two states with the largest class 4 land area, together account for $36 \%$ of the class 4 land area in the contiguous United States. Eleven states in the central United States--Colorado, Iowa, Kansas, Minnesota, Montana, North Dakota, Nebraska, Oklahoma, South Dakota, Texas, and Wyoming--have more than $95 \%$ of the class 4 land area in the contiguous United States. The state with the most class 3 land area is Texas, although percentages of land in class 3 in four states (Iowa, Kansas, Nebraska, and Oklahoma) are higher than in Texas.

\subsection{SCENARIO 3 - ENVIRONMENTAL AND MODERATE LAND-USE EXCLUSIONS}

In Scenario 3, we excluded all the environmental and urban 1 and, $50 \%$ of the forest 1 and, $30 \%$ of the agricultural 1 and, and $10 \%$ of the range 1 and. Exclusions for the other land-use types are listed in Table 3 under "Moderate". For this scenario, the U.S. land area with class 3 or greater is $65 \%$ of that 
with no exclusions (Scenario 1), as shown in Table 4c. The area with class 3 and higher resource is equivalent to an area approximately the size of California and Texas combined, whereas the area with class 4 and higher resource is equivalent to an area approximately the size of California (see Figure 6). The area with class 5 and higher resource is equivalent to an area larger than Maryland but smaller than West Virginia. The area with class 6 is equivalent to an area slightly smaller than New Jersey; most of the class 6 lands are located in Wyoming, where their area is equivalent to an area approximately the size of Connecticut. There are about $270 \mathrm{~km}^{2}$ of class 7 resource, an area equivalent to $10 \%$ of the size of Rhode Is 1 and. The class 7 lands are exposed ridge crests, mostly located in the mountainous areas of the West.

The moderate land-use exclusions alone had a greater effect on the areal estimates for class 3 and above than did the environmental exclusions. For example, about $225,000 \mathrm{~km}^{2}$ (equivalent to an area slightly larger than Kansas) were excluded under environmental restrictions, whereas about $343,000 \mathrm{~km} 2$ (equivalent to an area slightly smaller than Montana) were excluded under the moderate land-use restrictions. The percent reductions in lands with class 3 and higher resource under environmental and moderate land-use restrictions were $14 \%$ and $22 \%$, respectively, resulting in a combined reduction of $36 \%$. The percent reductions were largest for power classes 5, 6, and 7, which were $47 \%, 52 \%$, and $82 \%$, respectively. For these higher classes, more land was excluded by environmental restrictions than by moderate 1 and-use restrictions. In contrast, for classes 3 and 4 , more 1 and was excluded under moderate 1 anduse restrictions than under environmental restrictions. A large fraction of the class 3 and 4 areas is agricultural land, 30\% of which was excluded under the moderate land-use restriction, whereas only about 13\% of the class 3 and 4 areas is environmental land.

The distribution of windy land on a state-by-state basis for Scenario 3 is shown in Figure $7 \mathrm{a}$ for class 5 and greater and in Figure $7 \mathrm{~b}$ for class 3 and greater. A comparison of these two figures shows that the great majority of the power class 3 and 4 areas that appear in Figure 6 for the contiguous United States are concentrated in the Great Plains states. However, there are also some respectable amounts of windy land in the states of the Northeast. 
a) Wind Resource $\geq$ Class 5

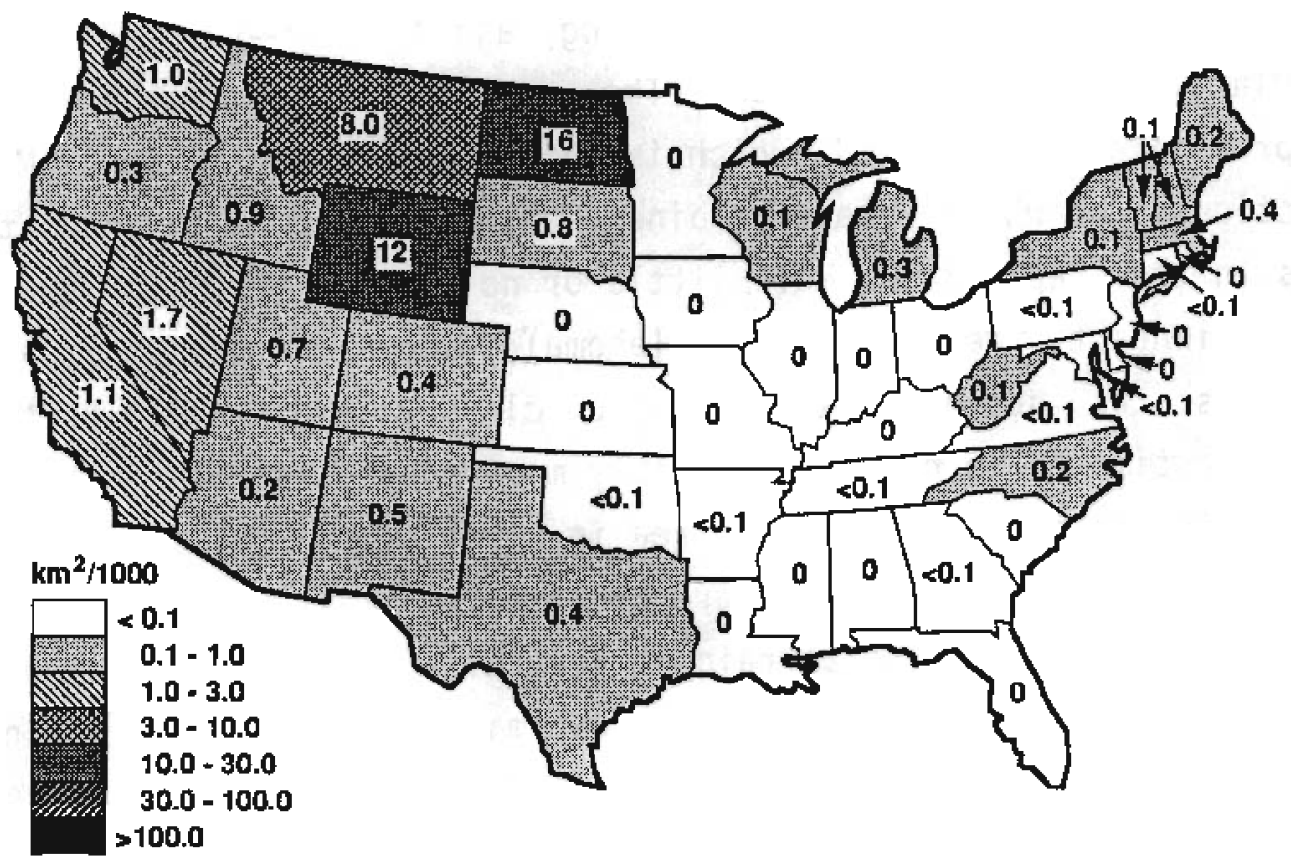

b) Wind Resource $\geq$ Class 3

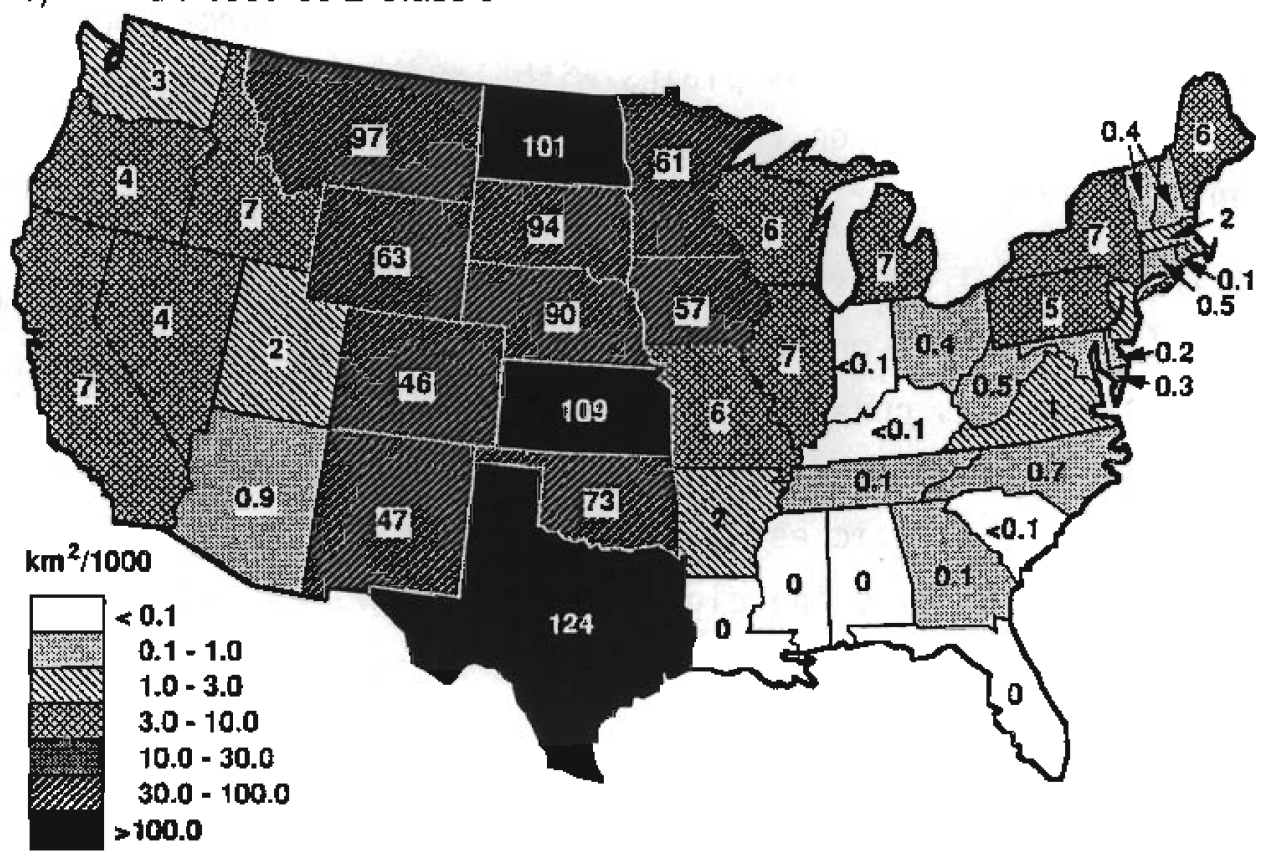

FIGURE 7. Available Windy Land (in Thousands of Square Kilometers) for Land Exclusion Scenario 3 and for a Wind Resource Specification of a) $\geq$ Class 5 and b) $\geq$ Class 3 
Windy land is shown as a percentage of a state's total area in Figure 8a for class 5 and greater and in Figure $8 b$ for class 3 and greater.

Three states--North Dakota, Wyoming, and Montana--have 79\% of the land with class 5 or greater resource. The combined class 5 area in these states is approximately $36,000 \mathrm{~km}^{2}$, which is equivalent to the sizes of Massachusetts, Connecticut, and Rhode Island combined. Although Figure 7 a shows that other states in the Great Plains have 1ittle or no class 5 area (for example, Iowa, Kansas, Minnesota, Nebraska, and Oklahoma), significant class 5 lands may exist in states that have large areas of class 4 land. While North Dakota has been estimated to have considerably more class 5 land area than other Great Plains states, the class 5 area in North Dakota could in fact be substantially less than estimated here because the class 5 sites appear to be located on relatively high terrain in generally flat areas of minor relief. The greatest uncertainty in the areal estimates for the Great Plains is in the specification of the percentage of land area that is represented by the assigned power class. This specification was dependent on the land-surface form classification. Thus our method assumed that $90 \%$ of the land area in the grid cells in eastern North Dakota had class 5 resource, because the landsurface form classification was plains with low relief. However, the class 5 sites are actually located on relatively high terrain, which may represent a significantly smaller fraction of the land area than $90 \%$.

Data from several areas of the Great Plains show that minor relief can have a significant effect on the wind resource and that the spatial variation of the wind resource is considerably greater than is indicated by the existing wind resource maps or implied by the land-surface form classifications. In the future, a more realistic estimate of the windy land area in the Great Plains may be achieved by using digital terrain data to identify minor relief features, such as normally imperceptible hills and ridges as well as slightly sheltered areas.

Twelve states in the midsection of the country (Texas, Kansas, North Dakota, Montana, South Dakota, Nebraska, Ok1ahoma, Wyoming, Minnesota, Iowa, New Mexico, and Colorado--listed in order by amount of the windy land area) have $92 \%$ of the U.S. Iand area with class 3 or greater. With $124,000 \mathrm{~km}^{2}$, Texas has the most windy land area, but this represents only $18 \%$ of the 
a) Wind Resource $\geq$ Class 5

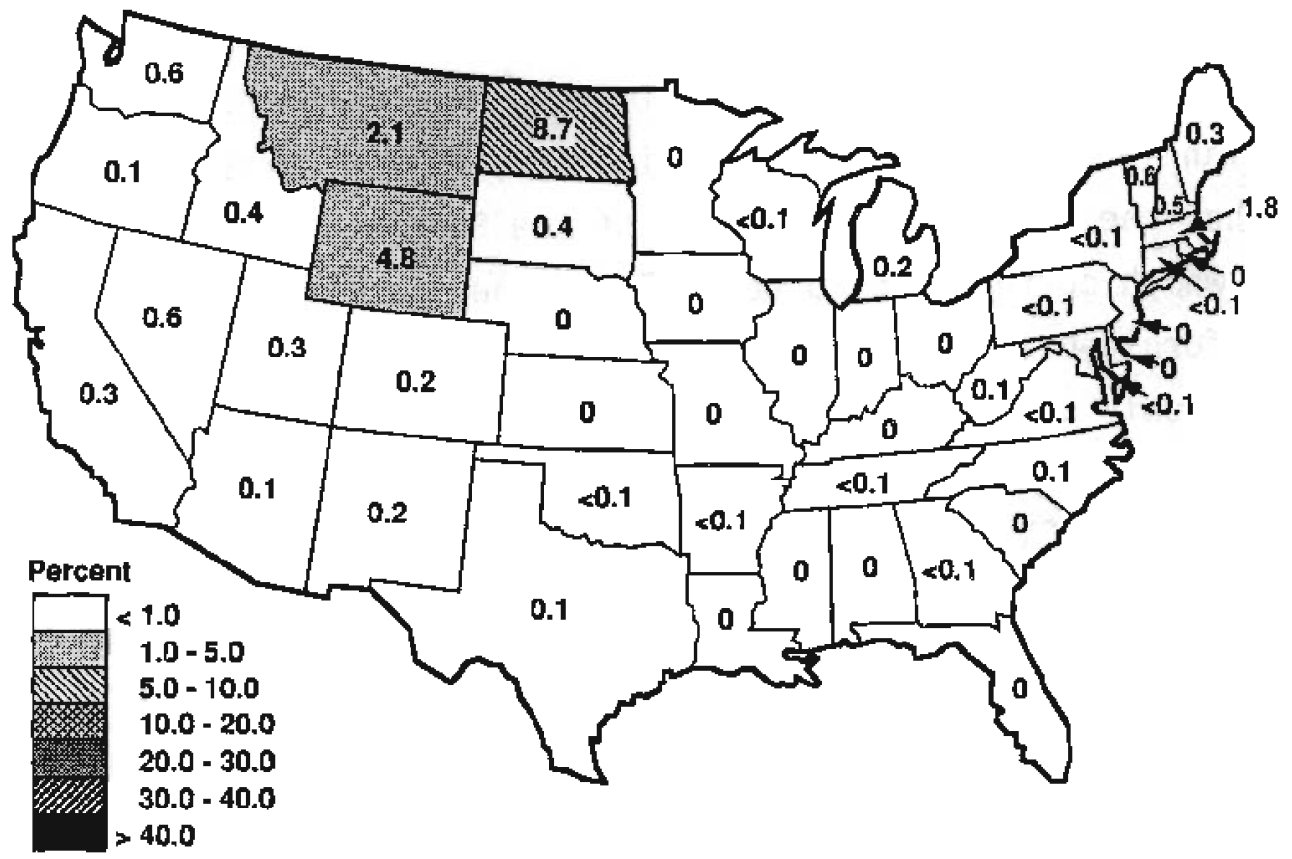

b) Wind Resource $\geq$ Class 3

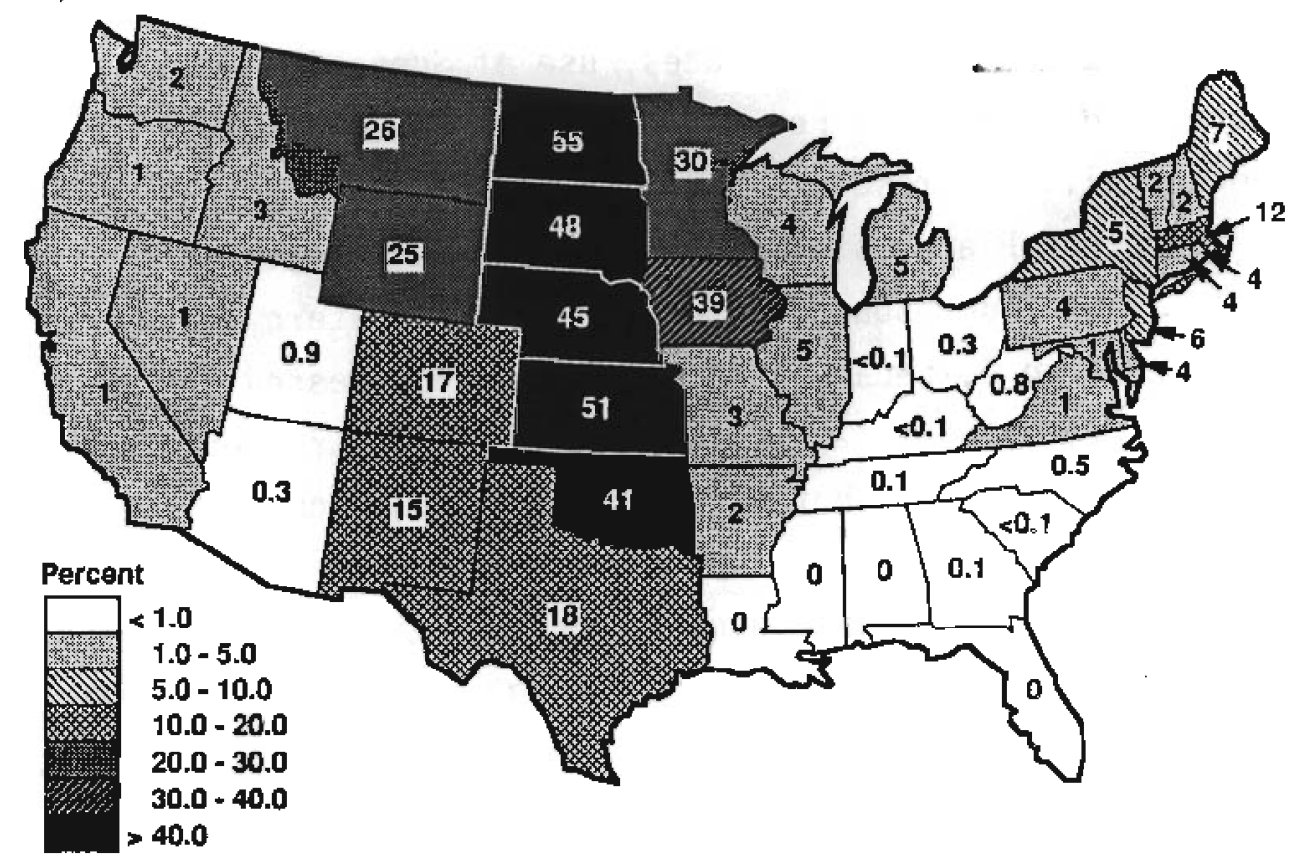

FIGURE 8. Available Windy Land as a Percentage of Each State's Total Area for Land Exclusion Scenario 3 and for a Wind Resource Specification of a) $\geq$ Class 5 and b) $\geq$ Class 3 
state's total land area. North Dakota may be considered the windiest state, with $55 \%$ of its land area estimated to have class 3 or higher resource, but Kansas is only slightly less windy with $51 \%$ of its land in class 3 or higher. In five states, more than $40 \%$ of the total land area has class 3 or higher resource (see Figure $8 \mathrm{~b}$ ). In the East, the state with the highest percentage of windy land area is Massachusetts with $12 \%$, which represents about $2500 \mathrm{~km}^{2}$. New York has the most windy land area of the East Coast states, with about $6600 \mathrm{~km} 2$, which corresponds to about $5 \%$ of the state's land area. For comparison, California has about $5200 \mathrm{~km}^{2}$ of land with class 3 or higher resource, but that is only slightly more than $1 \%$ of the state's total land area.

\subsection{SCENARIO 4 - ENVIRONMENTAL AND SEVERE LAND-USE EXCLUSIONS}

Scenario 4 (in which all environmental, agricultural, forest, and urban lands are excluded) severely reduces the resource. The factor in Scenario 4 that most reduces the land area is the $100 \%$ agricultural exclusion. For this scenario, the percentage of U.S. land area with class 3 or greater is on 1 y $27 \%$ of that in Scenario 1, which had no exclusions. The majority of this remaining $27 \%$ is range lands in the west.

In some areas of the United States, use of Scenario 4 would practically eliminate the wind resource. For example, Iowa would 1ose $99 \%$ of its wind resource potential. The resource potential would also be considerably reduced in many of the other plains states, where a large fraction of the land is agricultural. The wind resource potential in the eastern states is drastically reduced with Scenario 4, because they are largely forested and much of the land that is not forested is agricultural. Thus, the resource potential in those eastern states that do not have good coastal resources is essentially eliminated using Scenario 4. On the other hand, the resource in many of the western states survives Scenario 4 quite we11, because a large fraction of their wind resource areas is classified as range land. Thus Wyoming, under Scenario 4 , loses only about $30 \%$ of its resource potential, because most of the wind resource is located in range land. 


\subsection{ESTIMATES OF WIND ENERGY POTENTIAL}

To calculate the contribution that could be made by wind energy as an alternative or a supplement to conventional energy sources, the estimates of the windy 1 and area must be converted to estimates of electric power production that can be related to current and projected levels of energy consumption. This conversion can be accomplished with the gridded areal resource data, the gridded exclusion data, and specifications of turbine hub height, spacing, efficiency, and losses.

The total power intercepted over a given land area is a function of the number of wind turbines, the rotor-swept area of the wind turbine, and the total available power in the wind. This can be expressed as

$$
P_{I}=P_{C} A_{t} N_{t}
$$

where $\mathrm{P}_{\mathrm{I}}=$ power intercepted

$P_{C}=$ average wind power density in a vertical plane perpendicular to the wind

$A_{t}=$ rotor-swept area of the wind turbine

$\mathrm{N}_{\mathrm{t}}=$ number of wind turbines.

Nt depends on the total land area and the wind turbine spacing:

$$
N_{t}=\frac{A_{L}}{\left(S_{r} D\right)\left(S_{1} D\right)}
$$

where $A_{L}=1$ and area

$\mathrm{S}_{r}=$ spacing between turbine rows (in rotor diameters)

$S_{1}=$ lateral spacing between the turbines (in rotor diameters)

$D=$ turbine rotor diameter .

By substitution of $\mathrm{Eq}$. (2) into $\mathrm{Eq}$. (1), the average power intercepted (in MW) per square kilometer of land area can be calculated using 


$$
\mathrm{PI}_{\mathrm{I}} / \mathrm{AL}_{\mathrm{L}}=(\pi / 4) \mathrm{P}_{\mathrm{C}} / \mathrm{S}_{\mathrm{r}} S_{\mathrm{T}}
$$

The average power intercepted per square kilometer, for each wind power class 3 through 7, is given in Table 9 for a 50-m hub height and a spacing with $S_{r}=10$ and $S_{1}=5$. The average power output per square kilometer $\left(P_{0} / A_{L}\right)$, also shown in Table 9 for each power class, was calculated using

$$
P O / A_{L}=\left(P_{I} / A_{L}\right) E_{S}(1-L)
$$

where $E_{S}$ is the estimated system efficiency and $L$ represents the estimated power losses; both were specified as 0.25 in this case. A discussion of the turbine spacing, power losses, and efficiency assumptions is given in Appendix A.

Because the average power density values used for this report represent mean annual values, annual electric energy production potential (in MWh) per square kilometer can be calculated by multiplying the average power output values in Table 9 by 8760 (the number of hours in a year); dividing this number by 1000 yields the annual electric energy production potential in millions of $\mathrm{kWh} / \mathrm{km}^{2}$, also shown in Table 9.

To obtain the average power output for each grid cell over the contiguous United States, the value of the average power output per square kilometer for each power class in the grid cell is multiplied by the area of the land with

TABLE 9. Average Power Intercepted, Average Power Output, and Annual Energy Production per Square Kilometer of Land Area for Wind Resource $\geq$ Class 3,50-m Hub Height, 10D by 5D Spacing,

\begin{tabular}{|c|c|c|c|c|}
\hline $\begin{array}{l}\text { Power } \\
\text { Class }\end{array}$ & $\begin{array}{c}\text { Wind Power } \\
\text { Density, } \\
W / \mathrm{m}^{2} \\
\end{array}$ & $\begin{array}{c}\text { Average Power } \\
\text { Intercepted, } \\
M W / \mathrm{km}^{2} \\
\end{array}$ & $\begin{array}{c}\text { Average Power } \\
\text { Output, } \\
\text { MW/ } / \mathrm{km}^{2} \\
\end{array}$ & $\begin{array}{c}\text { Annual Energy } \\
\text { Production, } \\
\text { million } \mathrm{kWh} / \mathrm{km} 2 \\
\end{array}$ \\
\hline 3 & 350 & 5.50 & 1.03 & 9.02 \\
\hline 4 & 450 & 7.07 & 1.33 & 11.65 \\
\hline 5 & 550 & 8.64 & 1.62 & 14.19 \\
\hline 6 & 700 & 11.00 & 2.06 & 18.04 \\
\hline 7 & 900 & 14.14 & 2.65 & 23.21 \\
\hline
\end{tabular}
$25 \%$ Efficiency, and 25\% Power Losses 
the corresponding power class in the grid cell. These values are then summed for all the grid cells in each state; then, a total for the 48 states is computed to determine the wind electric potential for the contiguous United States. The results of this computation are shown in Tabie 10 and Figure 9, for the same set of land exclusion scenarjos as in Table 4 and Figure 6 .

The annual wind electric potential (in kwh) was converted to primary energy equivalent (in Btus) using a thermal conversion factor of $10,235 \mathrm{Btu} /$ $\mathrm{kWh}$. This thermal conversion factor was the average for electricity generated in 1988 at U.S. fossil fuel steam-electric power plants (Energy Information Administration 1990). This is the factor used by the Energy Information Administration (EIA) to convert hydroelectricity and electricity generated from wood, waste, wind, photovoltaic, and solar thermal energy to primary energy equivalents. In Table 10 and Figure 9, the annual wind energy potential (fossil-fuel equivalent) is given in units of Quads (quadrition Btus).

Table 11 gives the wind potential as a percentage of 1990 electric consumption (Energy Information Administration 1991), 1988 total energy consumption (Energy Information Administration 1990), and projected energy consumption in the year 2030 (Solar Energy Research Institute 1990). Total electricity consumed in 1990, based on the EIA's data on reported sales by electric utilities to ultimate consumers, was 2705.5 billion kwh. Total energy consumption, based on the EIA's 1988 data (the latest available at the time of this writing), was 80.2 Quads. These totals for electricity and energy consumption were for al1 50 states. In Table 11, we use the totals for just the 48 contiguous states, which were 2692.7 billion kwh for 1990 electric consumption and 79.4 Quads for 1988 total energy consumption.

The EIA noted that, because of the lack of consistent historical data, their energy consumption statistics exciude wood, waste, geothermal, wind, photovoltaic, and solar thermal energy (except for sinall amounts used by electric utilities to generate electricity for distribution). Rader et al. (1990) estimated that, when the amount of renewable energy unaccounted for by the EIA is added, the United States actually consumed closer to 83 Quads in 1988 . 

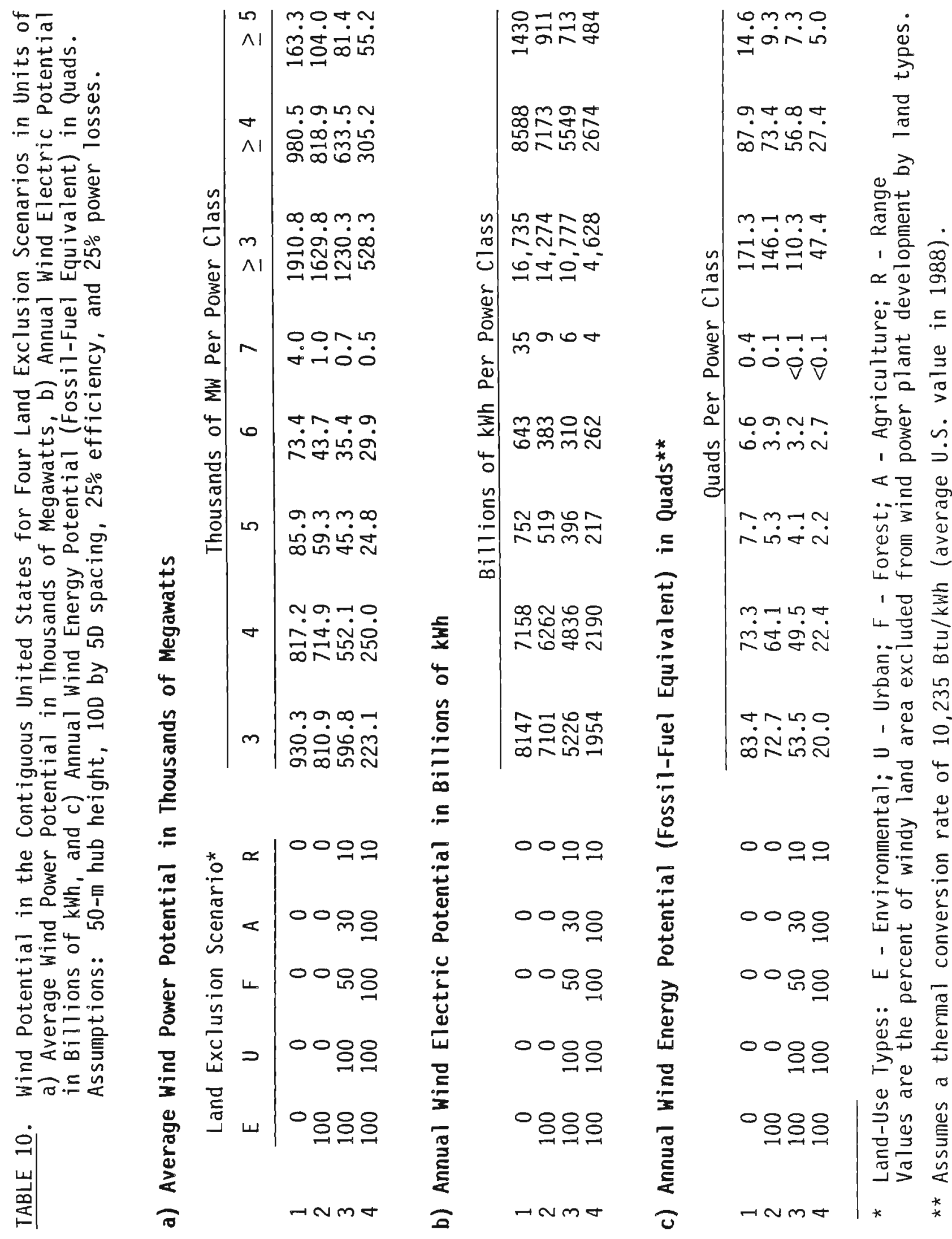


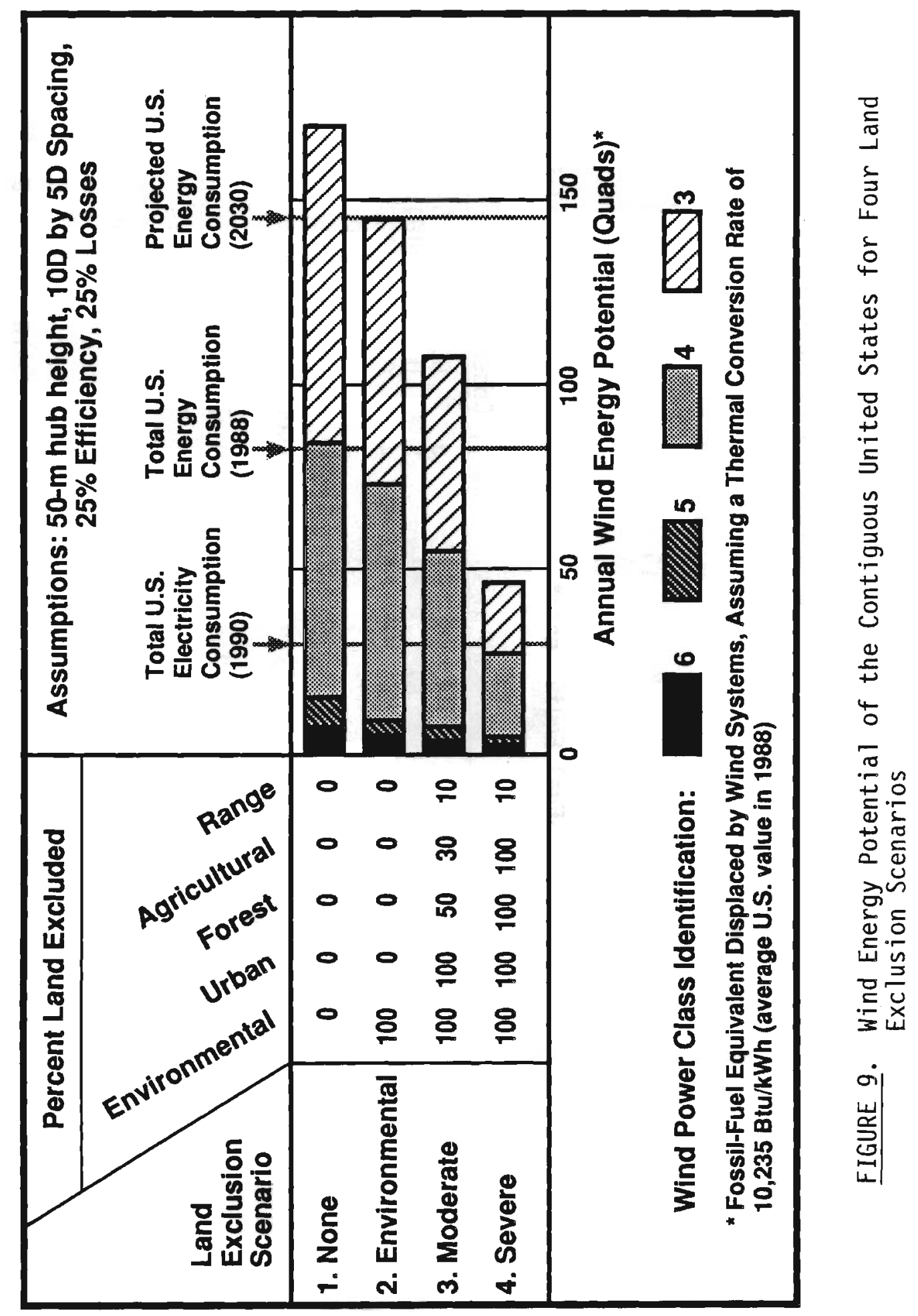




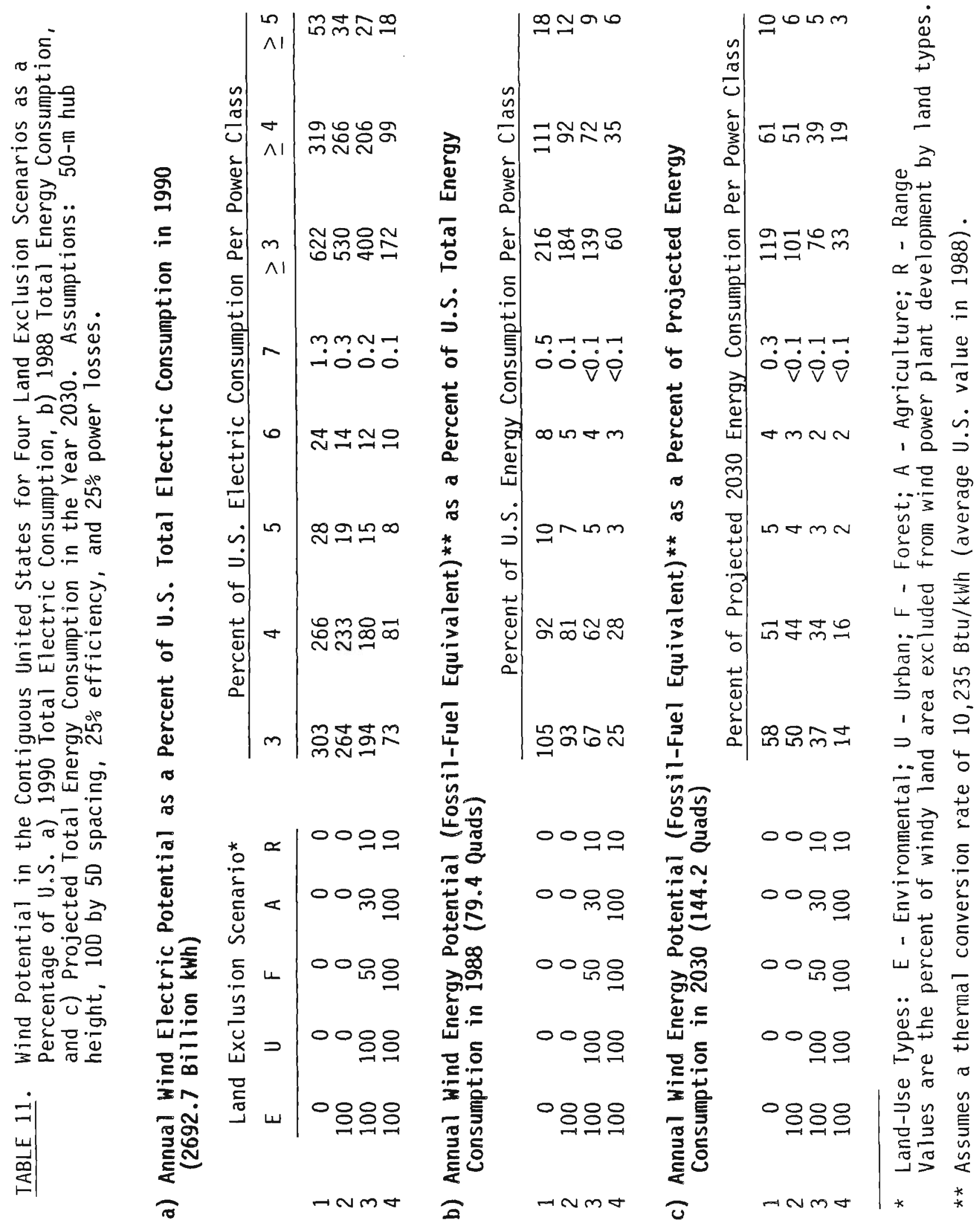


Our assumptions about the turbine were intended to include some features of an advanced design. For instance, the 50-m hub height is not typical of most of today's operational turbines. However, this hub height takes advantage of the increase of wind power with height that is common over much of the central United States. As can be seen from the 30- and 50-m power density values shown in Figure 6 , the resulting increase in power is $25 \%$. If other assumptions about turbine spacing, efficiency, or power losses are made, the wind energy potential shown in Table 10 and Figure 9 can be easily adjusted using ratios of the preferred assumptions to the ones used here. To determine the wind electric potential for a different spacing, multiply the values for the 100 by 50 spacing in Table 10 by the ratio $50 / S_{r} S_{1}$. For example, the ratio would be 0.5 for a 100 by 100 spacing $[i . e ., 50 /(10 * 10)]$. Table 12 gives ratios for various turbine spacings. Although we have assumed a power loss of 25\% (of which about 10 to $15 \%$ may be attributed to array losses caused by wind turbine wake effects) for the 100 by 50 spacing used in the calculations, the power ratios in Table 12 do not account for the effects of wind turbine spacing on array losses. At tighter spacings than 100 by 50, actual power ratios may be significantly less than indicated here because wake effects are greater with tighter spacings. Conversely, at wider spacings than 100 by 50, actual power ratios may be less than indicated here because wake effects are lower with wider spacings. The optimum turbine spacing depends on many factors, as discussed in Appendix A.

The striking feature of Figure 9 is that the wind energy resource for Scenario 3, even at the levels being tapped in California today (class 5 and above), has the potential to make a substantial contribution to meeting the nation's electrical and total energy needs. As shown in Table 11 for Scenario 3, the wind potential from class 5 and above is equivalent to about $27 \%$ (or $20 \%$ for a $30-\mathrm{m}$ hub height) of electrical consumption in the contiguous United States and about 9\% (or 7\% for a 30-m hub height) of the total energy consumption. In kilowatt-hours ( $k$ wh), the annual wind electric potential from all class 5 and higher resource areas is about 570 billion kwh (for a 30-ril hub height). Assuming a 25\% average capacity factor, the potential installed capacity would be about $260,000 \mathrm{MW}$ (the average power production over one year would be about 65,000 MW). California's installed wind 
TABLE 12. Power Ratios for Various Turbine Spacings in Comparison to That of the 10D by 5D Spacing Used in the Estimates of Wind Electric Potential

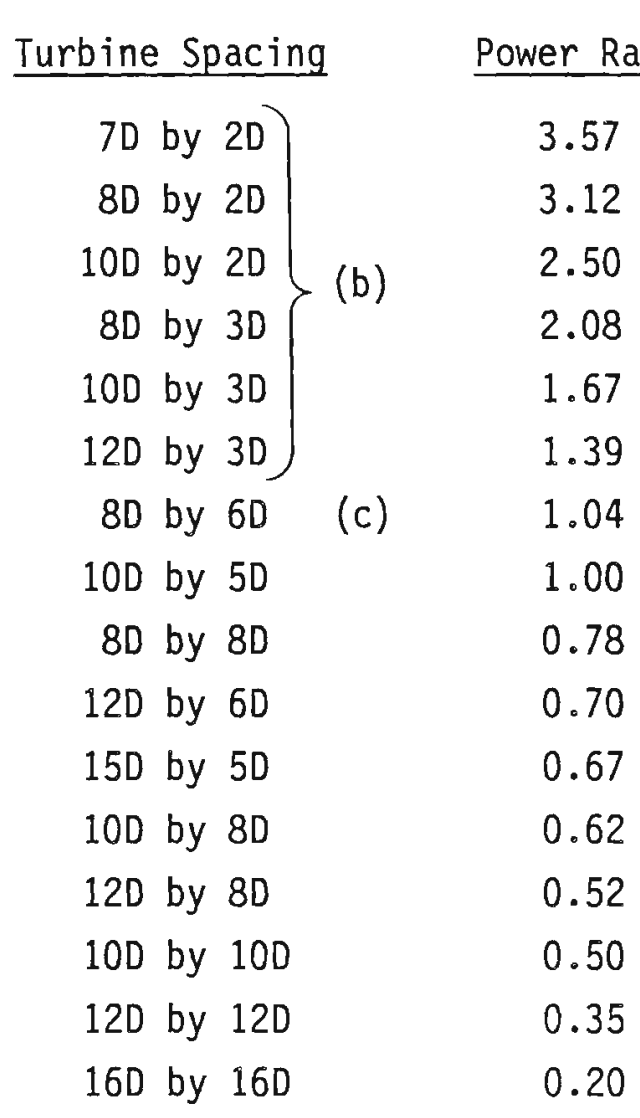

(a) These ratios do not account for effects of wind turbine wake interference on array losses, which are greater at tighter spacings.

(b) Typical spacing of many arrays in California.

(c) Typical spacing of arrays in Denmark.

capacity in 1990 was $1468 \mathrm{MW}$, which generated 2.42 billion $\mathrm{kWh}$, according to S. Rashkin, California Energy Commission (phone conversation July 19, 1991). Thus, the wind electric generation in California today is only about $0.5 \%$ of the total possible from all class 5 and higher wind resource areas in the contiguous United States.

When the technology has advanced to the point where power classes 3 and 4 can be tapped cost-effectively, the total wind potential for Scenario 3 will increase more than tenfold, to about 110 Quads fossil-fuel equivalent 
of electricity production annually (see Table 10c). The total annual wind electric potential from class 3 and above resource areas is equivalent to four times the electricity consumed in the contiguous United States in 1990 (see Table 11a). Even under the most severe land-use restriction (Scenario 4), in which virtually all but range and barren lands are excluded, the total annual wind electric potential is still about 1.7 times the current electric consumption. If wind resource areas of class 4 and higher are considered, the wind electric potential is approximately $200 \%$ and $100 \%$ of the contiguous U.S. electric consumption for the moderate and severe land-use exciusions, respectively.

Comparing the wind potential (fossil-fuel equivalent) to the total energy consumption in the contiguous United States, wind potential from class 3 and higher resource areas and under Scenario 3 is equivalent to almost $140 \%$ of the 1988 total energy consumption and about $75 \%$ of the energy consumption projected for the year 2030. Even under a severe land-use restriction (Scenario 4), these percentages reduce only to about $60 \%$ and $30 \%$, respectively.

To show the wind resource distribution over the country, wind electric potential by state is shown for Scenario 3 in Figure 10 . The wind electric potential estimates in Figure 10 are shown in units of thousands of MWavg, which represent average power potential. The MWavg can be multiplied by $8.76 \times 10^{-3}$ to get annual wind electric potential in billions of kwh (for example, $100,000 \mathrm{MWavg}=876 \mathrm{bi71}$ ion $\mathrm{kWh}$ per year) or divided by a capacity factor to estimate installed capacity. A large fossil-fueled steam or nuclear power plant typically produces around $1000 \mathrm{MWavg.} \mathrm{Because} \mathrm{the} \mathrm{wind} \mathrm{electric}$ potential estimates in Figure 10 are given in thousands of MWavg, the wind electric potential can easily be related to an equivalent number of large power plants. For example, the wind electric potential for Wyoming shown in Figure 10a $(20,000 \mathrm{MWavg})$ is equivalent to that produced by about 20 large power plants.

Figure 10a, which shows the wind electric potential for a $30-m$ hub height and wind resource of class 5 and above, is intended to represent the contribution possible with today's technology in areas that have wind resources comparable to the Caifornia passes currently supporting successful wind plants. Tabie 13 gives the average power output per square kiloneter of land area in 
a) 30-m Hub Height, Wind Resource $\geq$ Class 5 at $30 \mathrm{~m}$

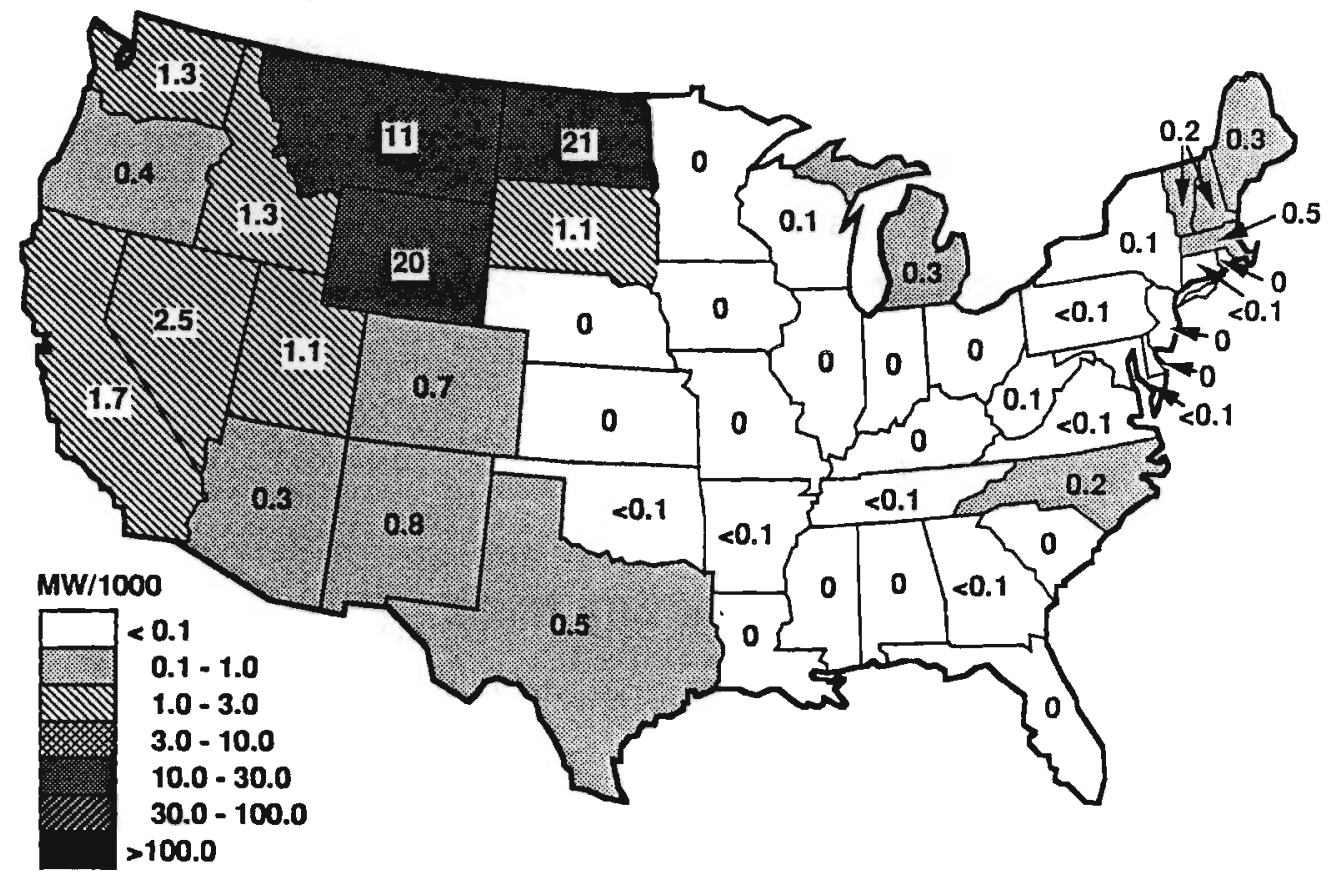

b) $50-\mathrm{m}$ Hub Height, Wind Resource $\geq$ Class 3 at $50 \mathrm{~m}$

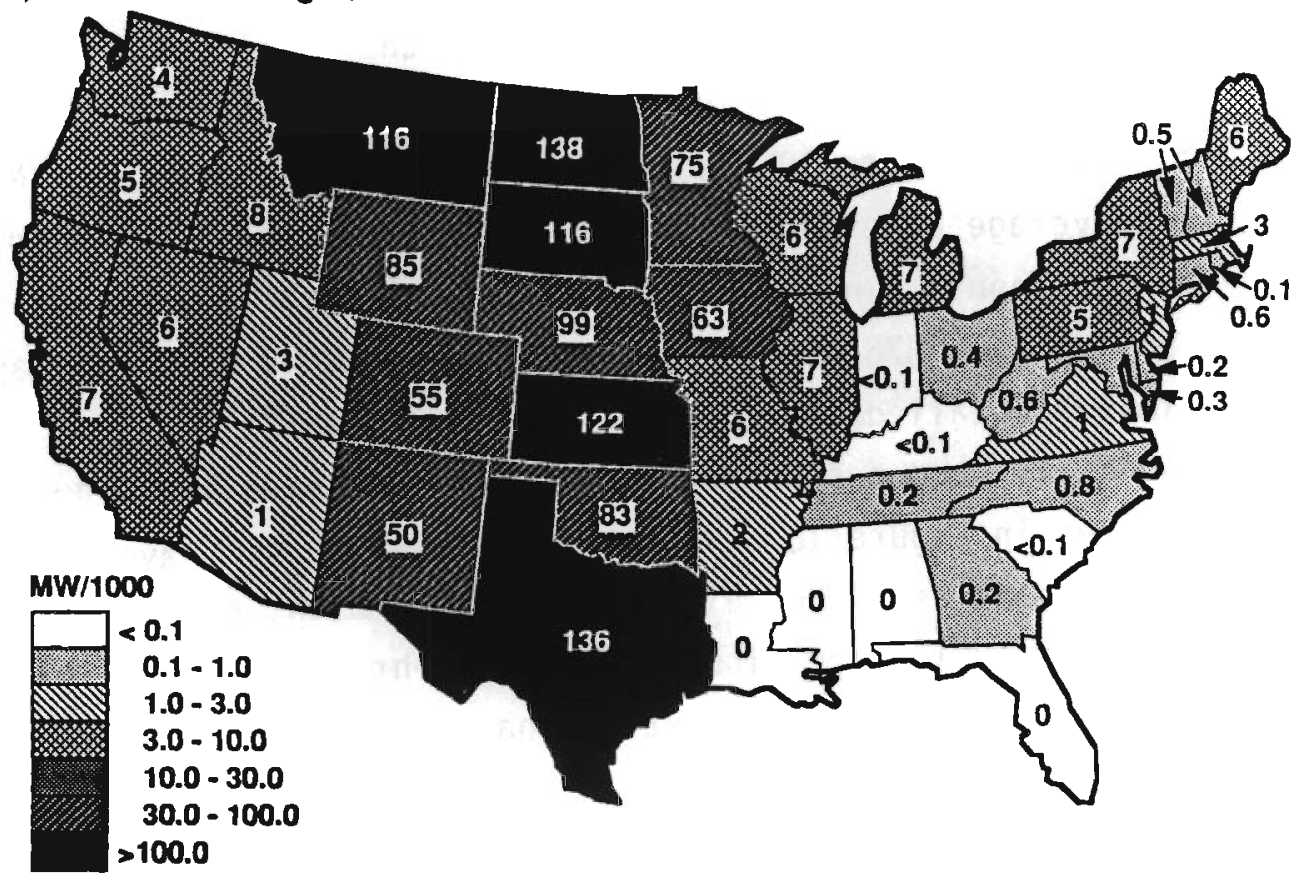

FIGURE 10. Wind Electric Potential (in Thousands of $\mathrm{MW}_{\text {avg }}$ ) for a) $30-\mathrm{m}$ Hub Height and Wind Resource $\geq$ Class 5 at $30 \mathrm{~m}$, and b) 50-m Hub Height and Wind Resource $\geq$ Class 3 at $50 \mathrm{~m}$. Other specifications are 10D by 5D spacing, 25\% efficiency, 25\% losses, and land exclusion Scenario 3. 
TABLE 13. Average Power Intercepted, Average Power Output, and Annual Energy Production per Square Kilometer of Land Area for Wind Resource $\geq$ Class 5, 30-m Hub Height, 100 by 50 Spacing, 25\% Efficiency, and 25\% Power Losses

\begin{tabular}{|c|c|c|c|c|}
\hline $\begin{array}{l}\text { Power } \\
\text { Class }\end{array}$ & $\begin{array}{l}\text { Wind Power } \\
\text { Density. } \\
W / m^{2} \\
\end{array}$ & $\begin{array}{c}\text { Average Power } \\
\text { Intercepted, } \\
\mathrm{MW} / \mathrm{km}^{2} \\
\end{array}$ & $\begin{array}{c}\text { Average Power } \\
\text { Output, } \\
\text { MW/km2 } \\
\end{array}$ & $\begin{array}{c}\text { Annual Energy } \\
\text { Production, } \\
\text { million kwh } / \mathrm{km}^{2} \\
\end{array}$ \\
\hline 5 & 440 & 6.91 & 1.30 & 11.39 \\
\hline 6 & 560 & 8.80 & 1.65 & 14.45 \\
\hline 7 & 720 & 11.31 & 2.12 & 18.57 \\
\hline
\end{tabular}

power classes 5 and above for a 30-m hub height. This average was used in determining the wind electric potential estimates in Figure 10a. Note that the average power output values in Table 13 for a $30-\pi$ hub height are $20 \% 1$ ess than those in Table 9 for a 50-m hub height. Figure 10b, which shows the wind electric potential for a 50-m hub height and wind resource of class 3 and above, is intended to represent the contribution possible with advanced technology that allows areas with power classes 3 and 4 to be developed.

Probably the most dramatic change in the potential for individual states associated with technological advances occurs in several states in the central portion of the country (Iowa, Kansas, Minnesota, Nebraska, and 0klahoma, for example). These states go from having virtually no potential with current technology (Figure 10a) to being among the top 12 states with advanced technology (Figure 10b). Some of those states that were estimated to have substantial areas of class 4 wind resource, but essentially no class 5 areas based on the available data, may in fact have significant areas of class 5 resource that have not yet been identified. For example, since the completion of U.S. Wind Resource Atlas (Elliott et a1. 1987), an extensive area of about $2640 \mathrm{~km}^{2}$ estimated to have class 5 wind resource potential has been identified in Minnesota (Geisen 1990). The wind electric potential of this class 5 area in Minnesota is about 30 billion $\mathrm{kwh}$ (using our assumptions in converting the 1 and area to wind electric potential), which is equivalent to about $63 \%$ of the state's 1990 electric consumption. More detailed wind resource assessment studies are needed to determine whether significant class 5 areas also exist in the other states that are shown in the U.S. Wind Resource Atlas as having large areas of class 4 resource. 
The enormous contrast between the wind electric potentials shown to be available in Figures $10 \mathrm{a}$ and $10 \mathrm{~b}$ tends to take attention away from the fact that some contributions within particular states are notable, even for wind potential of class 5 and above. For example, although the wind electric potential for the contiguous 48 states shown in Figure 10a is less than $8 \%$ of that shown in Figure 10b, the wind electric potential from class 5 or greater wind resource areas in North Dakota, Wyoming, and Montana contributes about $80 \%$ of the U.S. wind electric potential from class 5 or higher resource areas. The wind electric potentials from areas of class 5 and higher resource in North Dakota, Wyoming, and Montana exceed the 1990 electric consumption in these states by factors of $25.6,14.8$, and 7.4 , respectively.

To put the wind electric potential available with advanced turbine technology into perspective with recent electric (1990) and total energy (1988) consumption, we computed each state's wind potential as a percentage of the entire U.S. current electric and total energy consumption. These percentages were calculated from the wind electric potential values shown in Figure 10b. The results are shown in Figures $11 a$ and $11 b$ for electric and total energy consumption, respectively.

In Figures 11a and 11b, 12 contiguous states in the midsection of the country contribute over $90 \%$ of the wind energy potential of all 48 states. In order of greatest potential, these states are North Dakota, Texas, Kansas, South Dakota, Montana, Nebraska, Wyoming, Oklahoma, Minnesota, Iowa, Colorado, and New Mexico. In addition to the fact that the wind energy potential in these states is such a high percentage of the U.S. electric consumption and total energy consumption, each of these states also has the potential to produce several times its own consumption. This would put them in a position to export electric power or use it for other purposes.

Another feature that appears in Figure $11 \mathrm{a}$ is that, in addition to the 12 states that are the major contributors to wind electric potential, five states in the West, four states in the Midwest, and three states in the Northeast regions show a wind electric potential of meeting $1 \%$ to $3 \%$ of the total electric needs for the contiguous United States. 
a) Total Electric Consumption

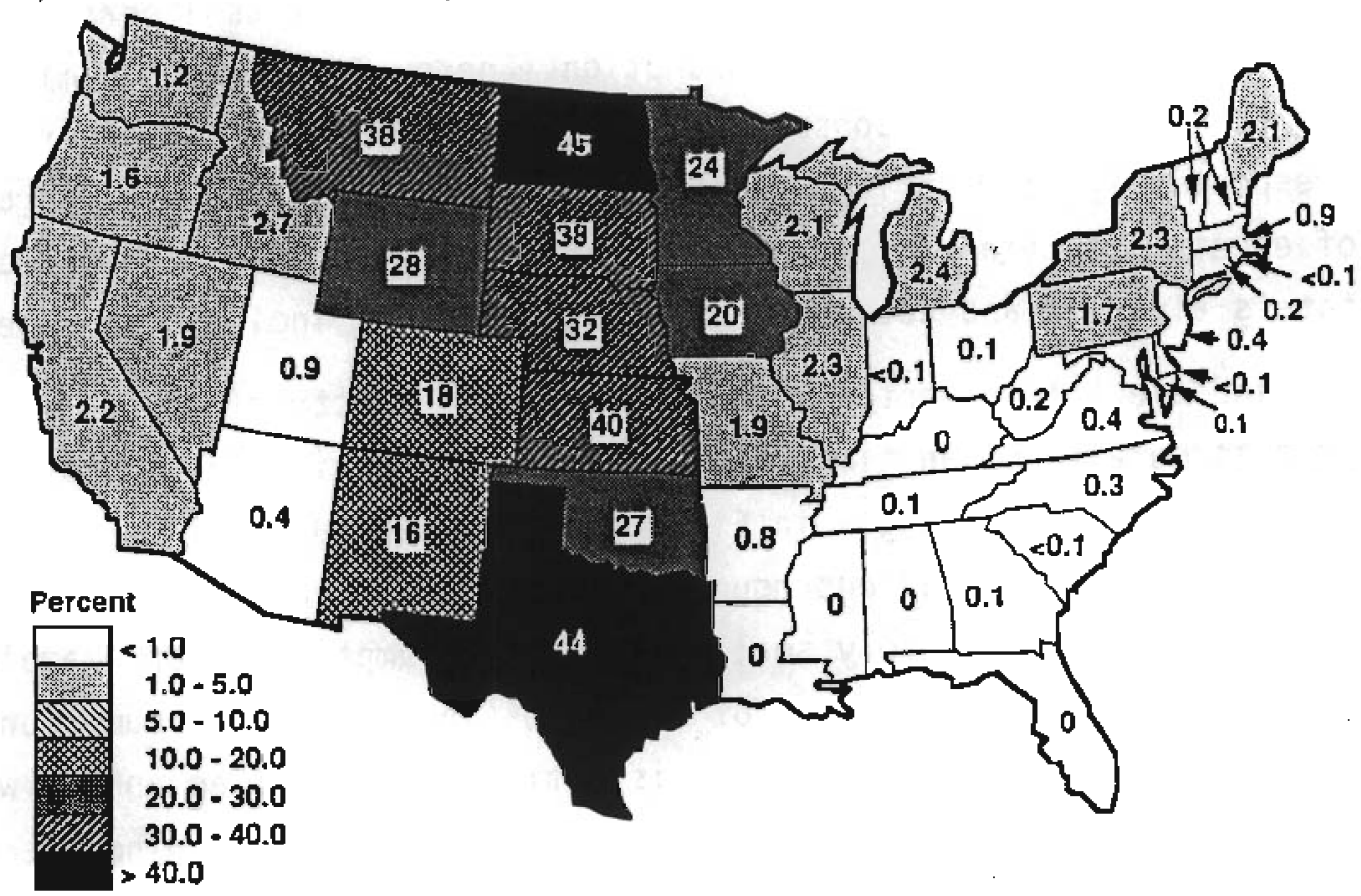

b) Total Energy Consumption

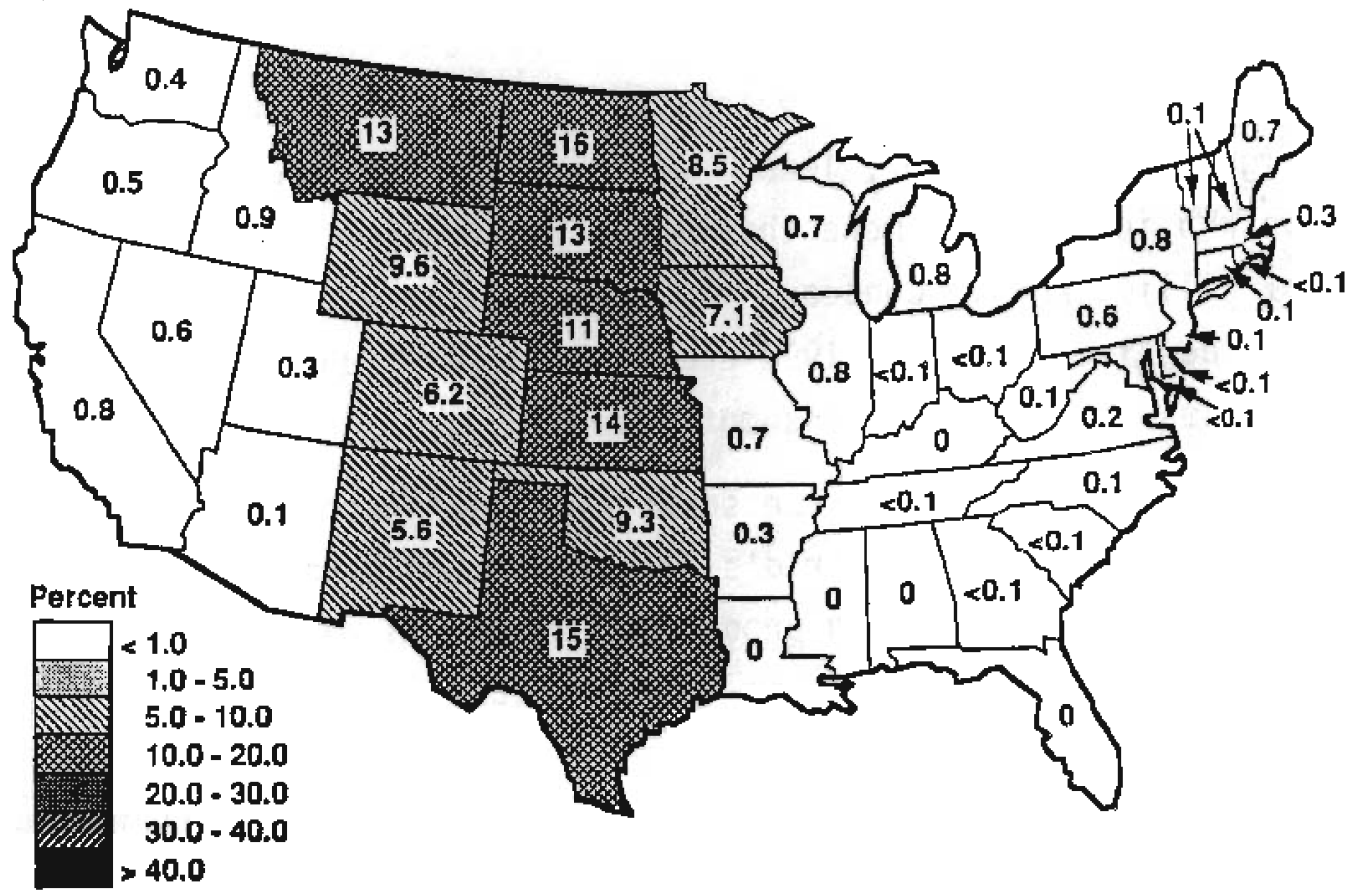

FIGURE 11. Wind Electric Potential as a Percentage of Contiguous U.S. a) 1990 Total Electric Consumption and b) 1988 Total Energy Consumption. Specifications: $50-m$ hub height and wind resource $\geq \mathrm{Class} 3$ at $50 \mathrm{~m}, 10 \mathrm{D}$ by $5 \mathrm{D}$ spacing, $25 \%$ efficiency, $25 \%$ losses, and land exclusion Scenario 3 . 
Figures $12 \mathrm{a}$ and $12 \mathrm{~b}$ show the wind electric potential as a percentage of each state's 1990 total electric consumption (Energy Information Administration 1991) and 1988 total energy consumption (Energy Information Administration 1990), respectively. Electric consumption as reported by the EIA represents sales of electricity (in $\mathrm{kWh}$ ) to ultimate consumers within a state. Data for each state's electric and total energy consumption are included in Appendix $B$.

The wind electric potential exceeds the total electric consumption in 17 states and is more than ten times the electric consumption in 11 states. The extremely large percentages in Figure 12 for the states of North Dakota and South Dakota reflect the enormous wind resource potential in these states in comparison to the relatively small electric consumption. For example, North Dakota, which ranks 45th out of 48 states in electric consumption with only 7.1 billion kWh consumed in 1990, is estimated to have an annual wind electric potential of 1210 billion kWh. Thus, North Dakota's wind electric potential is estimated to be approximately 170 times (or $17,000 \%$ of) its total electric consumption.

Texas, the state with the greatest electric and total energy consumption, is estimated to have only slightly less wind potential than North Dakota, as shown in Figure 10b. However, Texas' electric consumption of almost 238 billion kWh in 1990 was more than 33 times greater than that of North Dakota (7.1 billion kWh). Consequently, Texas' wind electric potential is estimated to be five times its 1990 electric consumption and only slightly greater than its total energy consumption.

California, the state with the second largest electric and total energy consumption, is currently the world's leader in wind generation (with over $80 \%$ of the world's capacity) and produced 2.4 billion kWh in 1990 from 1468 MW of installed capacity. According to our estimates, the total wind potential in California from class 3 and higher wind resource areas is equivalent to about $28 \%$ of its current electric consumption, which was 211 billion kwh in 1990. 
a) Total Electric Consumption

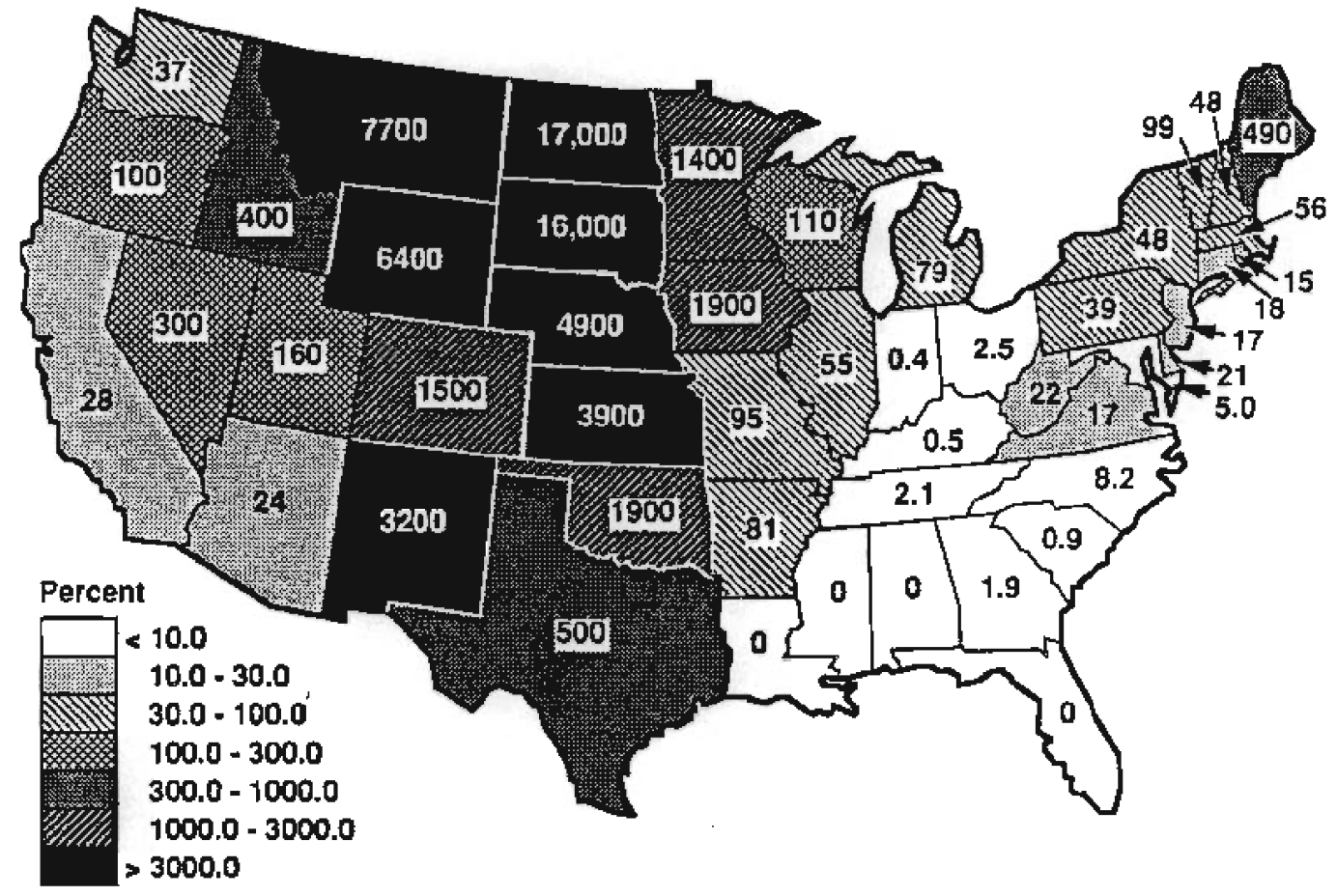

b) Total Energy Consumption

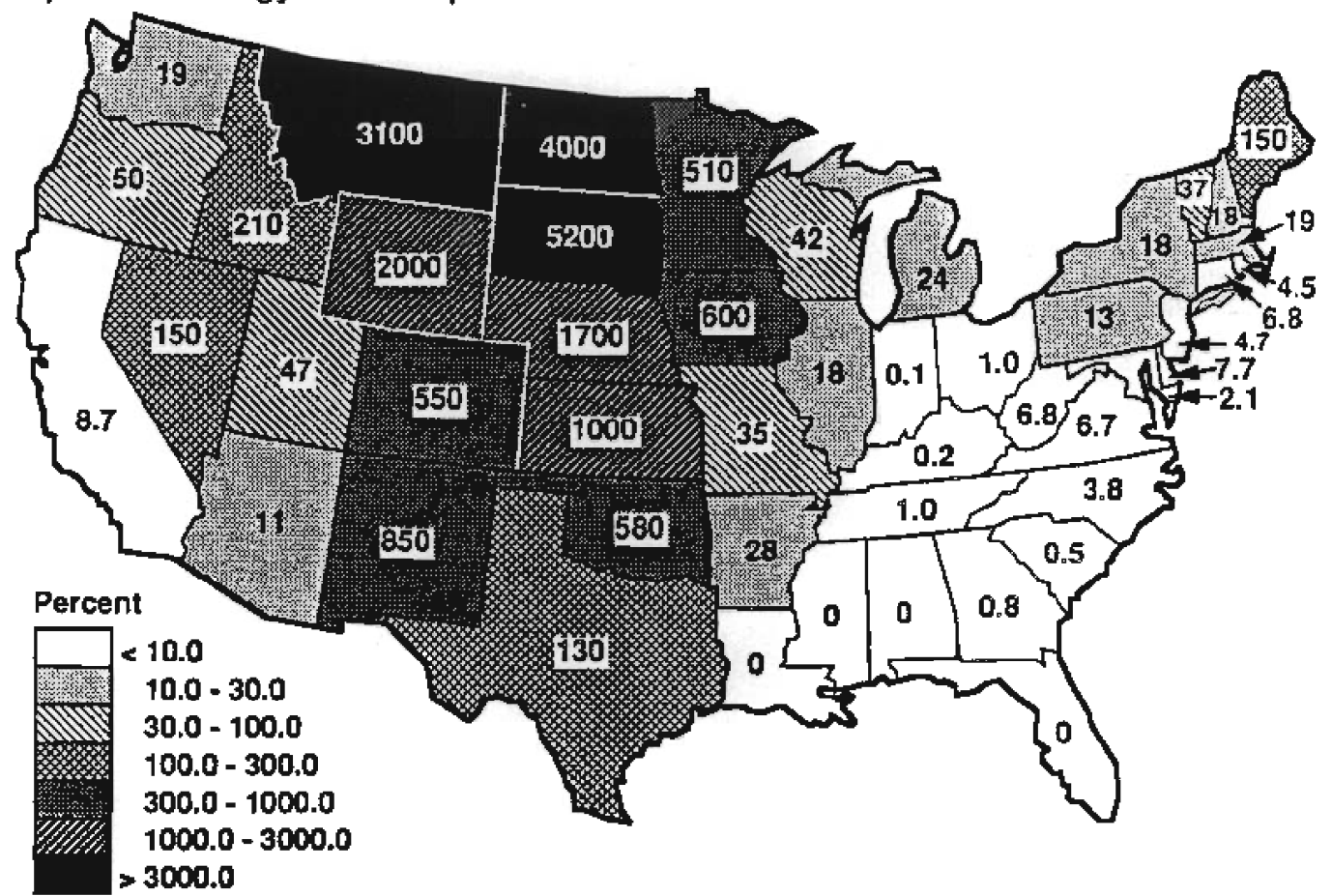

FIGURE 12. Wind Electric Potential as a Percentage of Each State's a) 1990 Total Electric Consumption and b) 1988 Total Energy Consumption. Specifications: $50-m$ hub height and wind resource class 3 at $50 \mathrm{~m}, 100$ by 50 spacing, 25\% efficiency, 25\% 10sses, and 1 and exclusion Scenario 3. 


\subsection{CONCLUSIONS AND RECOMMENDATIONS}

The primary conclusion to be drawn from this analysis is that wind energy over the contiguous United States is not limited by the availability of windy lands. That is, the wind resource has the potential of supplying a substantial fraction of the nation's energy needs, even with the use of today's technology.

Today's technology allows the exploitation of the wind resource mainly in specific areas where the annual average wind resource is class 5 or greater. To date, development of these areas has occurred primarily in California, where class 5 areas are being developed cost-effectively. Although this study shows that, after exclusions, only about $0.6 \%$ of the contiguous U.S. land area is characterized by class 5 or greater wind resource, the wind electric potential that could be extracted from these areas across the United States with today's technology is equivalent to about $20 \%$ of the current U.S. electric consumption. Three states--North Dakota, Wyoming, and Montana--could contribute about $80 \%$ of the U.S. wind electric potential from class 5 or greater wind resource areas.

Future advances in wind turbine technology will further enhance the potential of wind energy in the United States. As advances in turbine technology al how development of lower wind resource areas, such as class 3 areas, more than a tenfold increase in the wind energy potential is possible. Areas with class 3 and higher wind resource represent approximately $13 \%$ of the contiguous U.S. 1and area. These areas, which cover large sections of the Great Plains stretching from Texas to the Dakotas but are also distributed throughout many other sections of the country, have the potential of displacing over 100 Quads (fossil-fuel equivalent) of electric energy annually. Compare that with the total energy use of approximately 80 Quads in the contiguous United States in 1988, with $36 \%$ of that consumption being devoted to the production of electricity. Twelve states in the midsection of the country contribute over $90 \%$ of the wind electric potential in the contiguous United States. They are, in order of greatest potential, North Dakota, Texas, Kansas, South Dakota, Montana, Nebraska, Wyoming, Oklahoma, Minnesota, Iowa, Colorado, and New Mexico. These states have the potential to produce several times their 
own electrical consumption, which puts them in a position to export electric power or use it for other possible applications.

This study has provided a quantitative estimate of the overall resource. However, we need to emphasize three qualifications concerning this study. First, the results presented herein must be regarded as estimates only and they would change with the use of different assumptions and specifications. Second, this study does not diminish the need for careful siting and array design before the actual installation of a wind plant. Third, wind is an intermittent resource, and wind technology must therefore be integrated with other baseload power sources to provide a stable utility system. Important factors not addressed in this study that do influence the area available and total wind electric potential include resource remoteness (transmission, access), production/demand match (seasonal and daily, storage), utility and public acceptance, local ordinances, and other technological and institutional factors.

There are two levels of refinement between this study and a detailed site evaluation that would be worthwhile to pursue. One is to perform seasonal analyses. The national wind energy resource data base contains gridded maps of seasonally averaged wind power density. Analyses by season, like those reported here for the annual averaged data, could be valuable to utility companies, especially if the analyses were done for their service areas.

The second level of refinement is to improve the terrain resolution and is particularly appropriate for the scale of a utility service area. This would involve replacing the gridded landform classification data with digital terrain data now available from the U.S. Geological Survey to develop a much finer resolution of the spatial distribution of the wind resource. This muchimproved spatial resolution in the analyses would bridge the gap that now exists between the gridded resource assessment results and the information required for detailed siting and array design efforts. 


\subsection{REFERENCES}

Elliott, D. L., C. G. Holladay, W. R. Barchet, H. P. Foote, and W. F. Sandusky. 1987. Wind Energy Resource Atlas of the United States. DOE/CH 10093-4, Solar Energy Research Institute, Golden, Colorado.

Energy Information Administration. 1990. State Energy Data Report: Consumption Estimates 1960-1988. D0E/EIA-0214(88), Energy Information Administration, Office of Energy Markets and End Use, U.S. Department of Energy, Washington, D.C.

Energy Information Administration. 1991. Electric Power Monthly. D0E/EIA0226(91/03), Energy Information Administration, Office of Energy Markets and End Use, U.S. Department of Energy, Washington, D.C.

Geisen, R. J. 1990. "Minnesota's Winds: Physical Limits of Wind Energy and WECS Viability." In Proceedings of Windpower 190, pp. 292-297. American Wind Energy Association, Washington, D.C.

Hammond, E. H. 1964. "Analys is of Properties in Landfom Geography: An Application to Broadscaie Landform Mapping." Annals, Association of American Geographers, 54:11-19, Map Supplement Number 4.

Hock, S. M., R. W. Thresher, and J. M. Cohen. 1990. "Performance and Cost Projections for Advanced Wind Turbines." Presented at American Society of Mechanical Engineers Winter Annual Meeting, Dallas, Texas, November 25, 1990. SERI/TP-257-3795, Solar Energy Research Institute, Golden, Colorado.

Kessler, E, and R. Eyster. 1987. Variability of wind Power near 0klahoma City and Implications for Siting of Wind Turbines, PNL-6293, Pacific Northwest Laboratory, Richland, washington.

Rader, A., K. Bossong, J. Becker, D. Borson, and C. Manuel. 1990. The Power of the States: A Fifty-State Survey of Renewable Energy. Public Citizen, Washington, D.C.

Solar Energy Research Institute. 1990. The Potential of Renewable Energy. SERI/TP-260-3674, Solar Energy Research Institute, Golden, Colorado. 
APPENDIX A

WIND TURBINE SPACINGS, ENERGY LOSSES, AND EFFICIENCY 
APPENDIX A

WIND TURBINE SPACINGS,

ENERGY LOSSES, AND EFFICIENCY

This appendix discusses the assumptions used for wind turbine spacing, power losses, and efficiency in developing the estimates of wind electric potential.

\section{WIND TURBINE SPACINGS AND ENERGY LOSSES}

A wind turbine spacing of 100 (row spacing) by 5D (1ateral spacing within a row), where $D$ is the rotor diameter, has been assumed. This spacing is more open than that of existing arrays of wind turbines in California and Hawai $i$, where typical spacings are about 100 by 20 . Winds at the California and Hawai sites are quite unidirectional, which permits tighter lateral spacing than in areas with winds whose direction is more variable. Lateral spacing typically ranges from about $1.5 \mathrm{D}$ to 3D, and row spacing from about 70 to 12D. The terrain features and wind flow variability often dictate the wind turbine layout, such that spacing within an array may vary considerably, especially in hilly areas such as Altamont Pass and Tehachapi in California. In some hilly areas, "stacking" of wind turbines at different heights (sometimes referred to as a "wind wall") along a ridge has been used to substantially increase the number of turbines and the net energy production without utilizing additional land area. In Denmark, where wind directions are more variable than in California and Hawai, more open spacings, such as 80 by 60, have been used.

The degree of array energy losses caused by wind turbine wakes has been difficult to determine with much accuracy because the ambient flow varies throughout many of the existing wind turbine arrays. The relatively shallow depth of the wind resource in Altamont Pass (where many array energy loss studies have been performed), in comparison to other regions, is another factor that brings into question the applicability of the Altamont Pass array energy loss data to other regions. 
Array loss data from arrays in California and Hawai indicate energy losses are in the range of 5 to $25 \%$. Published data on energy losses in large arrays are scarce. Most of the published data on array losses are for four or fewer rows of wind turbines. One set of data from a level site with an array of seven rows of wind turbines, with about a 9D by 2D spacing, indicates annual average array losses of about 15\% (Lynette 1986). Data collected downwind of large arrays indicate energy deficits on the order of 20 to $30 \%$ immediately downwind from the array (Nierenberg 1989). The problem of "wind rights" has now developed as a major issue in the siting of wind turbines in California and could possibly affect the geographical layout of arrays in the future.

Existing data show that array losses are a function of not only the turbine spacing, but also the turbine's thrust and power coefficients (which vary with the ambient wind speed) and the turbulence intensity of the wind (Liu 1988; Kelley 1989; Elliott and Barnard 1989; Nierenberg 1990). Wake deficits (as a percent of the ambient power, not an absolute value) are greatest at low wind speeds and low turbulence intensities. Wake and array loss models have been developed and verified with existing data (Veenhuizen et al. 1989; Lissaman et al. 1990); however, model results have not been verified for large arrays (the arrays modeled for verification had four or fewer rows of turbines).

The optimum spacing for arrays of wind turbines depends on the terrain, meteorological conditions, and turbine characteristics. In general, array losses may be reduced substantially by using more open spacings, such as $10 D$ by $10 D, 12 D$ by $8 D$, or 200 by $5 D$. It is possible that very open spacings, such as 160 by 160 , may drastically reduce array losses. However, the cost savings achieved by reducing the array losses with more open spacings must be weighed against the cost increases caused by spreading the array over a larger land area. All of these costs could vary from region to region and from site to site within a region. At many sites, the optimum spacing could ultimately be determined more by economic issues than by purely technical considerations. From a technical standpoint, both the key and the challenge are to accurately predict the optimal array layout, which will achieve the maximum energy output while keeping the array losses below an acceptable limit. 
Data from numerous arrays of wind turbines in California and Hawai $i$ indicate that typical energy losses from all causes were about 25\% (Lynette 1989). of this amount, about $10 \%$ was attributed to array losses caused by wake interference and about $15 \%$ was attributed to other causes, such as soiled blades, downtime, and wire losses. Improved airfoils have been designed to minimize losses from soiled blades, such as that caused by soiling from insects (Tangler et al. 1990).

We have assumed a 100 by 5D spacing and have allowed for energy losses of $25 \%$. The same spacing ( 100 by 50 ) is used for all types of terrain, although in reality spacing will be altered substantially by the terrain features. For example, in complex terrain consisting of narrow ridges perpendicular to the prevailing wind directions, where wind turbines are sited only on the ridge crests, the spacing between rows would depend on the separation distance between ridges. On ridges where winds are unidirectional, close lateral spacings, such as 1.5D, may be suitable, and even "stacking" of wind turbines at different hub heights may be considered.

Although a significant fraction of the windy land area of the United States is ridge crest, much of the windy land area is relatively flat terrain (such as the Great Plains), where a spacing of 10D by 50 is assumed to be generally applicable. Closer spacings than this are currently used in flat terrain areas in California, such as San Gorgonio Pass, but the wind directions in these California passes are mostly unidirectional. In Denmark, where wind directions are more variable than in the California passes, a spacing of approximately 80 by 60 was used in a wind farm of 42 300-kw machines located in flat coastal terrain (Taylor 1990); array loss data are not yet available for this wind farm.

If the wind directions are widely distributed, then a more open spacing, such as 100 by 100 , may be required. However, in many flat, windy regions of the United States, the primary directions of prevailing strong winds are not as widely distributed as might be expected. For example, in much of the Great Plains, the prevailing power-producing winds (on an annual basis) are mostly from opposite direction sectors (e.g., northerly and southerly sectors with only a small percentage from easterly and westerly sectors). This type of wind regime may permit closer lateral spacings, in contrast to a wind regime 
with wind directions that are widely distributed. On the other hand, at sites with relatively low turbulence, greater downwind spacing (e.g., 150) may be necessary.

\section{WIND TURBINE EFFICIENCY}

The wind turbine efficiency, which is the ratio of the net energy capture to the total available energy in the wind, is typically about 25 to $30 \%$ for current technology (on an annual average basis). The system efficiency is a function of a wind turbine's power coefficient, which varies with wind speed. For the advanced wind turbines, system efficiencies are projected to be 30 to $35 \%$. We have conservatively assumed a system efficiency of $25 \%$ in developing the estimates of wind electric potential.

\section{REFERENCES}

Elliott, D. L., and J. C. Barnard. 1989. Detailed Analysis of the Wake and Free-Flow Characteristics of the Goodnoe Hills MOD-2 Site. PNL-6921, Pacific Northwest Laboratory, Richland, Washington.

Kelley, N. D. 1989. "An Initial Look at the Dynamics of the Microscale Flow Field Within a Large Wind Farm in Response to Variations in the Natural Inflow." In Proceedings of Windpower '89, pp. 20-24. American Wind Energy Association, Washington, D.C.

Lissaman, P. B. S., D. T. Lindberg, and J. B. Armstrong. 1990. "Development of the Advanced AV-Lissaman Wind Turbine Array Interference Mode1." In Proceedings of the European Community Wind Energy Conference, pp. 163-165. H. S. Stephens and Associates, Bedford, England.

Liu, H.-T, J. W. Buck, A. C. Germain, M. E. Hinchee, T. S. Solt, G. M. LeRoy, and R. A. Srnsky. 1988. Field Investigation of Wake Structure Downwind of a VAWT in a Wind Farm Array. SERI/STR-217-3370, Solar Energy Research Institute, Golden, Colorado.

Lynette, R. 1986. Wind Power Stations: 1985 Performance and Reliability. EPRI AP-4639, Electric Power Research Institute, Palo Alto, California.

Lynette, R. 1989. Assessment of Wind Power Station Performance and Reliability. EPRI GS-6256, Electric Power Research Institute, PaTo A1to, California.

Nierenberg, R. 1989. "Macro-Scale Wake Effects." In Proceedings of Windpower 89 , pp. 14-19. American Wind Energy Association, Washington, D.C. 
Nierenberg, R. 1990. Wake Deficit Measurements on the Jess and Souza Ranches, Altamont Pass. SERI/TP-257-3455, Solar Energy Research Institute, Golden, Colorado.

Tangler, J., B. Smith, D. Jager, and T. 01sen. 1990. "SERI Thin-Airfoii Blade Atmospheric Performance Test: Final Resu1ts." In Proceedings of

Windpower ' 90, pp. 118-125. American Wind Energy Association, Washington, D.C.

Taylor, G. J. 1990. "Full Scale Measurements in Wind Turbine Arrays." In Proceedings of the 1990 European Community Wind Energy Conference and

Exhibition, pp. 154-158, H. S. Stephens and Associates, Bedford, England.

Veenhuizen, S. D., T. J. McCoy, J. T. Lin, and J. H. Rumbaugh. 1989.

"Modeling Wind Turbine Array Wake Effects." In Proceedings of Windpower 189 ,

pp. 7-13. American wind Energy Association, Washington, D.C. 


\section{APPENDIX B}

ESTIMATES OF WINDY LAND AREA AND

WIND ENERGY POTENTIAL, BY STATE 
APPENDIX B

ESTIMATES OF WINDY LAND AREA AND

WIND ENERGY POTENTIAL, BY STATE

Table B.1 provides estimates of windy land area and wind energy potential for each state in the contiguous United States. The windy land area and wind energy potential are calculated for an advanced wind turbine technology scenario that would allow areas with class 3 or higher wind resource to be developed. These areas have an annual average wind power density of at least $300 \mathrm{~W} / \mathrm{m}^{2}$ at heights of $50 \mathrm{~m}$. The windy land area is calculated by the method described in Chapter 5.0. Estimates are given for the total windy land area (prior to exclusions), the windy land area excluded from wind energy development, and the potentially available windy land area (after exclusions). Windy lands excluded were $100 \%$ of the environmental and urban lands, $50 \%$ of the forest lands, $30 \%$ of the agricultural lands, and $10 \%$ of the range 1 ands. (This exclusion was Scenario 3, the moderate land exclusion, described in Chapter 5.0).

The wind energy potential is caiculated by the method described in Chapter 6.0. We have assumed a 100 by 50 spacing, $50-\mathrm{m}$ hub height, $25 \%$ efficiency, and $25 \%$ losses. (These are the same assumptions as used for the advanced wind turbine technology scenario described in Chapter 6.0). The wind energy potential is expressed in units of 1) annual average power in $\mathrm{MW}$, 2) annual energy production in billions of kWh, and 3) annual fossil-fuel equivalent, in trillions of Btu, displaced by wind systems assuming a therma? conversion rate of $10,235 \mathrm{Btu} / \mathrm{kWh}$ (average U.S. value in 1988). One Quad (or one quadrillion Btu) equals 1000 trillion Btu. The annual energy production potential is also expressed as a percent of the current (1990) electricity consumed in the state and in the contiguous United States. The electricity consumption totals for 1990, which are given in column three of Table B.1, are based on the Energy Information Administration's (EIA's) data on reported sales of electricity to ultimate consumers within the state. The annual fossil-fuel equivalent of the wind energy potential is aiso expressed as a 


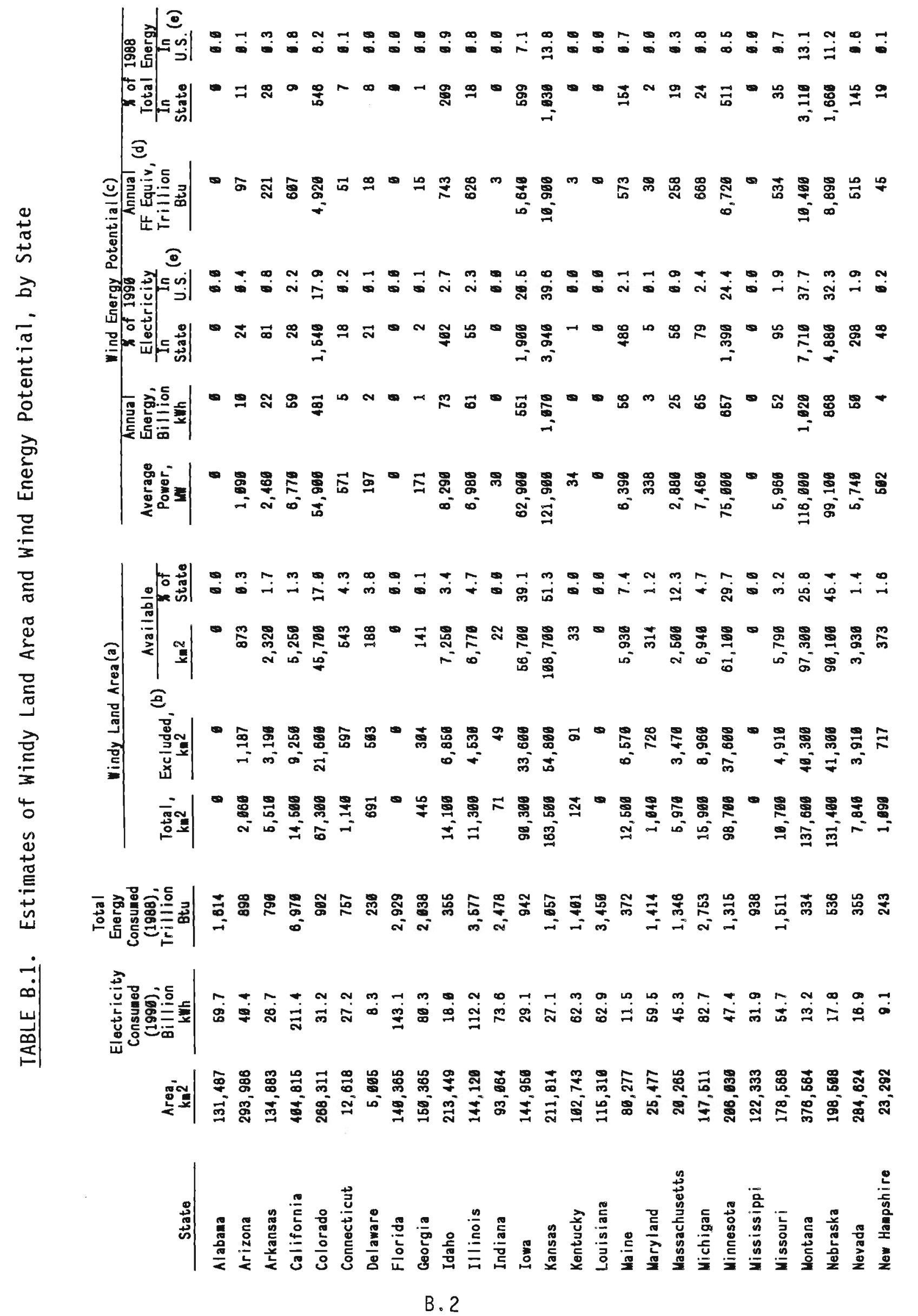




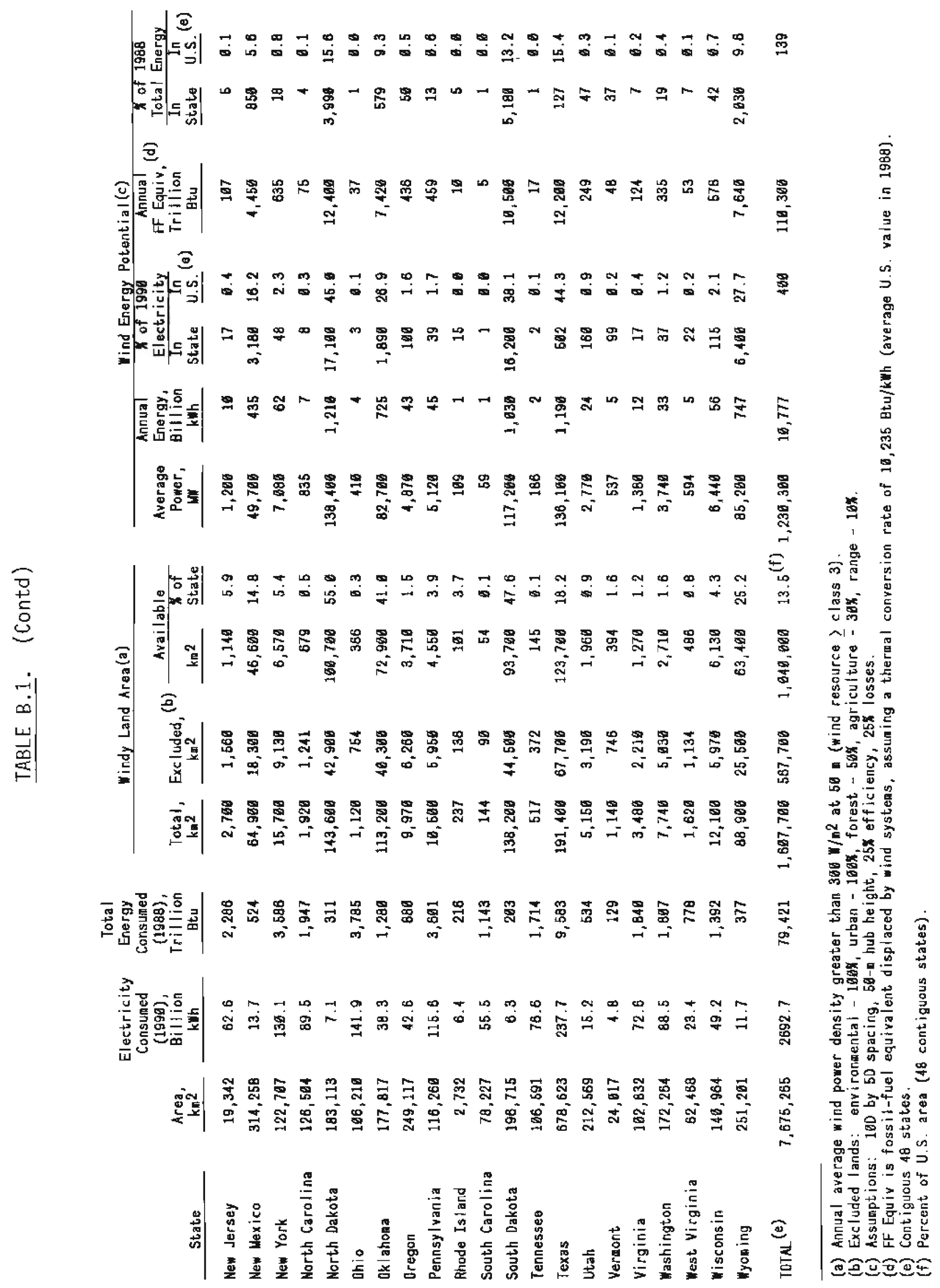

$$
\text { B. } 3
$$


percent of the total energy consumed (in 1988) in the state and in the contiguous United States. The 1988 total energy consumption data, which were the most recent available from the EIA at the time of this writing, are given in column four.

The TOTAL line at the bottom of Table B.1 provides information for the contiguous United States. 


\section{DISTRIBUTION}

No. of

Copies

OFFSITE

12 DOE Office of Scientific and Technical Information

R. Loose

U.S. Department of Energy

1000 Independence Avenue, SW

Mail Stop CE-351

Washington, DC 20585

D. F. Ancona

U.S. Department of Energy

Wind/Hydro/Ocean Division

1000 Independence Avenue, S.W.

ForrestaT Building, Rm. 5F064

Washington, DC 20585

J. B. Cadogan

U.S. Department of Energy

Wind/Hydro/Ocean Division

1000 Independence Avenue, S.W.

Forrestal Building, Room 5F064

Washington, DC 20585

C. Castellano

U.S. Department of Energy

Wind/Hydro/Ocean Division

1000 Independence Avenue, S.W.

Forrestal Building, Rm. 5F064

Washington, DC 20585

B. Armistrong

Seawest Industries

1455 Frazee Road, Suite 300

San Diego, CA 92108

C. I. Aspliden

Route 1, Box 125

Roseland, VA 22967

B. Bailey

AwS Scientific, Inc.

55 Colvin Avenue

Albany, NY 12206
No. of

Copies

R. W. Baker

2777 NW Wintergreen Place

Corvallis, OR 97330

G. C. Barlowe

Northern Power Systems

1 North Wind Road

Moretown, VT 05660

M. Bergey

Bergey Windpower

2001 Priestley Avenue

Norman, OK 73069

T. Bernadowski

Virginia Power

5000 Dominion Boulevard

Glen ATlen, VA 23050

D. Blittersdorf

NRG Systems, Inc.

P.0. Box 509

Hinesburg, VT 05461

N. Butler

RMGB

Bonneville Power Administration

P.0. Box 3621

Portland, $O R \quad 97208$

J. Bzura

New England Power Service Company 25 Research Drive

Westborough, MA 01582

J. W. Carter, Sr.

Wind Eagle Corporation

4302 Arnold Drive

Wichita Falls, TX 76302

J. Chapman

15 Sleeper Street

Number 402

Boston, MA 02210 
No. of

Copies

R. N. Clark

USDA-Agricultural Research

P.0. Drawer 10

Bushland, TX 79012

J. Cohen

SAIC

4300 King Street, \#310

Alexandria, VA 22302

C. Coleman

Northern Power Systems

1 North Wind Road

Moretown, VT 05660

C. Council

Western Area Power Authority

Mail Code A0-410

P.0. Box 3402

Golden, C0 80401

K. Cous ineau

Zond Systems Incorporated

13000 Jameson Road

Tehachapi, CA 93561

E. Davis

U.S. Windpower

6952 Preston Avenue

Livermore, CA 94550

J. Dehlsen

Zond Systems

P.0. Box 1910

Tehachapi, CA 93581

E. A. DeMeo

Electric Power Research Institute P.0. Box 10412

Palo Alto, CA 94303

$5 \quad H$. Dodd

Sandia National Laboratories

Division 6225

P.0. Box 5800

Albuquerque, NM 87185
No. of

Copies

D. M. Dodge

Solar Energy Research Institute 1617 Cole Boulevard

Golden, CO 80401

R. Dracker

Pacific Gas \& Electric

3400 Crow Canyon Road

San Ramon, CA 94583

J. R. Dunlop

Minnesota Department of Public Service

900 American Center Building

150 E. Kellogg Boulevard

St. Paul, MN 55101

R. Farrell

Altamont Group, Inc.

P.0. Box 1109

Inverness, CA 94937

C. Flavin

Worldwatch Institute

1776 Massachusetts Avenue, NW

Washington, DC 20036

W. Gerards

Kansas Gas \& Electric Company

120 E. First Street

Wichita, KS 67201

A. Germain

U.S. Windpower

6952 Preston Avenue

Livermore, CA 94550

J. Ghilardi

SeaWest Industries

1455 Frazee Road

Suite 300

San Diego, CA 92108-4304

P. Gipe

Kern Wind Energy Association

P.0. Box 277

Tehachapi, CA 93581 
No. of

Copies

R. Halet

Northern States Power Company

Research Department

414 Nicolet Mall

Minneapolis, MN 55401

J. B. Headrick

TU Electric

400 N. 01 ive

Lock Box 81

Dallas, TX 75201

P. C. Helgeson

Minnesota Department of Public Service

900 American Center Building

150 E. Kellogg Boulevard

St. Paul, MN 55101

D. $\mathrm{Hi} 11$

North Dakota Association of Rural Electric Cooperatives

P.0. Box 727

Mandan, ND 58554

5. Hock

Solar Energy Research Institute

1617 Cole Boulevard

Golden, Co 80401

S. Holets

Pacific Gas \& Electric Company

215 Market Street, Rm. 454

San Francisco, CA 94106

M. A. Ilyin

Pacific Gas \& Electric Company

3400 Crow Canyon Road

San Ramon, CA 94583

G. Johnson

EECE Department

Durland Hall

Kansas State University

Manhattan, KS 66506
No. of

Copies

R. Johnson

Princeton Economic Research

Institute

12300 Twinbrook Parkway

Suite 650

Rockville, MD 20852

J. G. Jones

Solar Energy Research Institute

1617 Cole Boulevard

Golden, Co 80401

S. Jones

Southwestern Public Service Company

Box 1261

Amarillo, TX 79170

N. Kelley

Solar Energy Research Institute 1617 Cole Boulevard

Golden, c0 80401

J. Kline

456 Larchwood Place

0akley, CA 94561

R. Langdon

ICF, Inc.

409 12th Street, SW

Suite 700

Washington, DC 20024

N. Lenssen

Worldwatch Institute

1776 Massachusetts Avenue, NW

Washington, DC 20036

B. Liebowitz

New York Energy Research and Development Authority

2 Rockefeller Plaza

Albany, NY 12223

C. Linderman

Edison Electric Institute

701 Pennsylvania Avenue, NW

Washington, DC 20004-2695 
No. of

Copies

R. Lynette

R. Lynette \& Associates, Inc. 15032 N.E. 40th Street, Suite 206 Redmond, WA 98052

5 M. Marvin American Wind Energy Association 777 N. Capitol Street, NE, \#805 Washington, DC 20002

E. McCarthy

U.S. Windpower 6952 Preston Avenue

Livermore, CA 94550

A. H. Miller

10013 Tepopa Drive

Oakdale, CA 95361

S. Miller

California Energy Commission

Mail Stop 45

1516 9th Street

Sacramento, CA 95814

V. Nelson

Alternative Energy Institute

Box 248

Canyon, TX 79016

R. Nierenberg

153 Sacramento Avenue

San Anselmo, CA 94960

J. Ogden

Center for Energy \& Environmental Studies

Engineering Quadrangle

Princeton University

Princeton, NJ 08544

D. W. Osborn

U.S. Windpower

6952 Preston Avenue

Livermore, CA 94550
No. of

Copies

B. Parsons

Solar Energy Research Institute 1617 Cole Boulevard Golden, CO 80401

R. G. Putnam, Jr. Niagara Mohawk Power Corporation 300 Erie Boulevard, West

Syracuse, NY 13202

S. Rashkin

California Energy Commission

Mail Stop 45

1516 9th Street

Sacramento, CA 95814

W. Rogers

Council of Energy Resource Tribes

1990 Broadway, Suite 2600

Denver, CO 80202

M. Sacarny

Second Wind, Inc.

7 Davis Square

Somerville, MA 02144

W. Sass

Second Wind, Inc.

7 Davis Square

Somerville, MA 01244

L. Schienbein

Flowind Corporation

1183 Quarry Lane

Pleasanton, CA 94566

T. Schweizer

Princeton Economic Research Institute

12300 Twinbrook Parkway

Suite 650

Rockville, MD 20852

S. Selander

United Power Association

P.0. Box 800

Elk River, MN 55330-0800 
No. of Copies

R. Sherwin

Atlantic Orient Corporation

P.0. Box 1097

Norwich, VT 05055

R. Simon

434 0akdale Avenue

Corte Madera, CA 94925

S. B. Smiley

Traverse City Light \& Power

P.0. Box 308

Traverse City, MI 49685-0308

J. C. Smith

Electrotek Concepts, Inc.

10305 Dutchtown Road, Suite 103

Knoxville, TN 37932

D. R. Smith

Pacific Gas \& Electric Company

3400 Crow Canyon Road

San Ramon, CA 94583

W. J. Steeley

Pacific Gas \& Electric Company

3400 Crow Canyon Road

San Ramon, CA 94583

D. Suehiro

Hawaijan Electric Renewable Systems, Inc.

P.0. Box 730

Honolulu, HI 96808-0730

5 R. Swisher

American Wind Energy Association

777 N. Capitol Street, NE

Sujte 805

Washington, DC 20002

N. Terreri

Green Mountain Power Corporation

P.0. Box 850

S. Burlington, VT 05402
No. of

Copies

B. C. Thomas

Puget Sound Power \& Light Company

P.0. Box 97034 OBC-09N

Bellevue, WA 98009-9734

10 R. W. Thresher

Solar Energy Research Institute

1617 Cole Boulevard

Golden, CO 80401

V. Tracy

Utah Power \& Light Company

$1407 \mathrm{~W}$ North Temple

Salt Lake Cjty, UT 84140

W. A. Vachon

W. A. Vachon \& Associates, Inc.

P.0. Box 149

Manchester, MA 01944

J. Wade

Pacific Wind Energy

P.0. Box 1671

Corvallis, OR 97339

C. J. Weinberg

Pacific Gas \& Electric Company

3400 Crow Canyon Road

San Ramon, CA 94583

C. Wiley

Phillips Laboratory

Hanscom AFB

Bedford, MA 01731

R. H. Williams

Center for Energy \& Environmental Studies

Engineering Quadrangle

Princeton University

Princeton, NJ 08544

J. Zimmerman

Green Mountain Power Corporation P.0. Box 850

S. Burlington, VT 05401 
No. of

Copies

FOREIGN

R. Reid

Canadian Wind Energy Association

153, 3rd Avenue

Ottawa, Ontario

CANADA K1S $2 \mathrm{Jg}$

ONSITE

DOE Field Office, Richland

E. C. Norman/R. B. Goranson

128 Pacific Northwest Laboratory

W. R. Barchet

J. C. Barnard

R. M. Ecker

D. L. Elliott (107)

J. W. Falco

G. L. Gower

L. K. Grove

J. M. Hales

P. C. Hays

V. R. Morris

R. L. Skaggs

L. L. Wendell (5)

Publishing Coordination

Technical Report Files (5) 